\title{
Relative abundance, temporal distribution, and functional feeding groups of aquatic insects in two first-order southwestern Pennsylvania streams
}

Judith S. Steinberg

West Virginia University

Follow this and additional works at: https://researchrepository.wvu.edu/etd

\section{Recommended Citation}

Steinberg, Judith S., "Relative abundance, temporal distribution, and functional feeding groups of aquatic insects in two first-order southwestern Pennsylvania streams" (2002). Graduate Theses, Dissertations, and Problem Reports. 1643.

https://researchrepository.wvu.edu/etd/1643

This Dissertation is protected by copyright and/or related rights. It has been brought to you by the The Research Repository @ WVU with permission from the rights-holder(s). You are free to use this Dissertation in any way that is permitted by the copyright and related rights legislation that applies to your use. For other uses you must obtain permission from the rights-holder(s) directly, unless additional rights are indicated by a Creative Commons license in the record and/ or on the work itself. This Dissertation has been accepted for inclusion in WVU Graduate Theses, Dissertations, and Problem Reports collection by an authorized administrator of The Research Repository @ WVU.

For more information, please contact researchrepository@mail.wvu.edu. 


\title{
Relative Abundance, Temporal Distribution, and Functional Feeding Groups of Aquatic Insects in Two First Order Southwestern Pennsylvania Streams
}

\author{
Judith S. Steinberg
}

\author{
Dissertation submitted to the \\ Davis College of Agriculture, Forestry, and Consumer Sciences \\ at West Virginia University \\ in partial fulfillment of the requirements \\ for the degree of

\section{Doctor of Philosophy} \\ in \\ Agricultural Sciences
}

\author{
Linda Butler, Ph.D., Chair \\ James W. Amrine, Jr., Ph.D. \\ Gary K. Bissonnette, Ph.D. \\ Kyle J. Hartman, Ph.D. \\ Joseph A. Marshall, Ph.D. \\ Division of Plant and Soil Sciences \\ Morgantown, West Virginia \\ 2002
}

Keywords: stream invertebrates, functional feeding groups, first order streams, Pennsylvania streams, relative abundance

Copyright 2002 Judith S. Steinberg 


\begin{abstract}
Relative Abundance, Temporal Distribution, and Functional Feeding Groups of Aquatic Insects in Two First Order Southwestern Pennsylvania Streams
\end{abstract}

Judith S. Steinberg

Two first to second order streams (Kent Run and Munnell Hollow) at Ryerson Station State Park, Greene County, Pennsylvania, were compared as to water parameters (dissolved oxygen, hardness, temperature, $\mathrm{pH}$, and current velocity), species diversity, and abundance of both immature and adult insects. Samples were taken biweekly for one year from May, 1999 through April, 2000 for a total of 26 sampling periods. Data were analyzed using a repeated measures ANOVA. Kent Run had lower dissolved oxygen, higher $\mathrm{pH}$ and hardness, lower temperatures, and higher current velocity. A total of 137 taxa were collected at both streams. Of the total 3,299 individuals collected at Kent Run, 1,166 were adults and 2,133 were immatures. Munnell Hollow had 1,273 adults and 890 immatures for a total of 2,163 individuals. For the adult and immature community metrics, there was a higher number of shredder taxa and a greater percentage of shredders at Munnell Hollow, both a higher number of taxa and a higher percentage of both collector-filterers and collector-gatherers at Kent Run, a higher number of scraper taxa and a greater percentage of scrapers at Kent Run, an equal number of predator taxa at each stream, and a higher percentage of predators at Munnell Hollow. Overall, community metrics were significantly higher for May 12-14, 1999 and April 24-26, 2000, indicating an optimal time for sampling for assessment of community metrics. The combination of the water parameters at Kent Run and its wider area and higher number of leaf packs, snags, and debris dams contributed to the higher numbers of individuals collected. 


\section{Dedication}

This dissertation is dedicated to my family and friends, especially my daughters

Rachel and Rebecca, who have given much love, support, encouragement, and most of all - believed in me. 


\section{Acknowledgements}

I would like to especially thank Dr. Linda Butler for all of her help and encouragement, but particularly for the example she has set as a professor, researcher, and mentor during this $\mathrm{Ph}$. D. journey.

I would also like to thank the other members of my graduate committee: Drs. James W. Amrine, Jr., Gary K. Bissonnette, Kyle J. Hartman, and Joseph A. Marshall who have been very helpful and added perspective and dimension to the project.

I would like to acknowledge the help of Dr. James Amrine, Jr., Mr. Robert Lake, Dr. Boris Kondratieff, and Dr. Chen Young who helped to identify the invertebrates collected.

Thanks also to Dr. Amrine for the stream calculations and DeLorme Topomaps.

Also, I would like to thank Dr. Michael B. Griffith for his invaluable help with the statistical analysis.

Finally, I would like to thank Katie Hunter for all of her computer assistance. 


\section{Table of Contents}

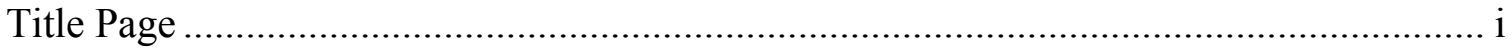

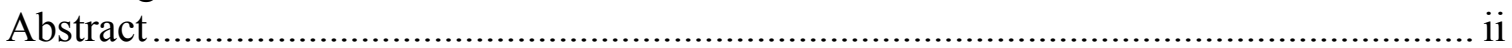

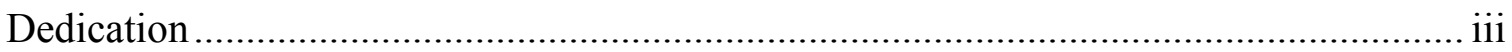

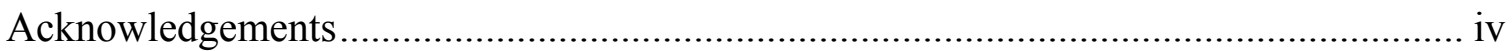

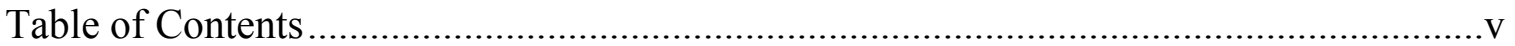

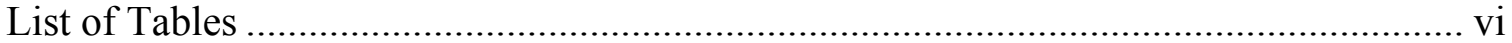

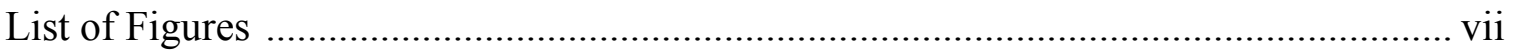

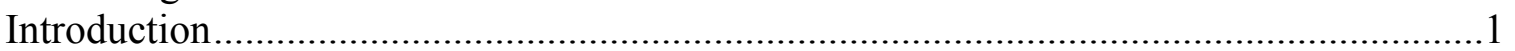

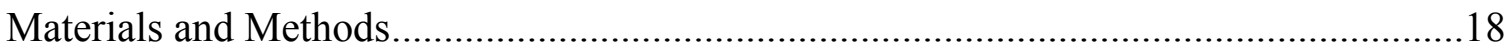

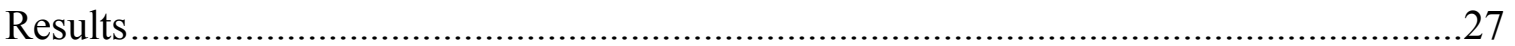

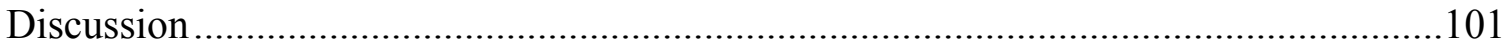

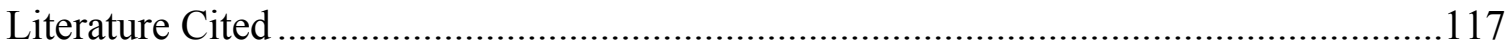

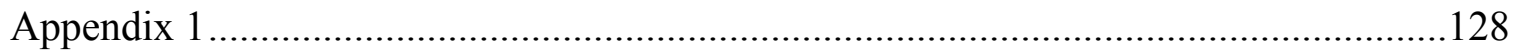

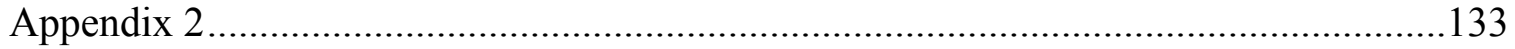

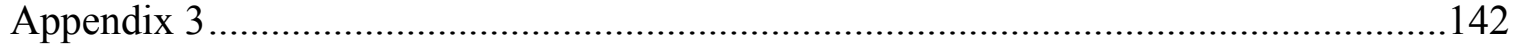

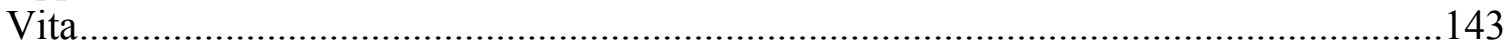




\section{List of Tables}

Page

Table 1. Sampling period and calendar dates for Kent Run and Munnell Hollow

Table 2. Summary of comparison (ANOVA) of water parameters between Kent Run and Munnell Hollow.

Table 3. Total number of individuals, total present as adults, and total present as immatures at each stream for each sample period.

Table 4. Total number of taxa and totals collected as adults and immatures at each stream at each sample period.

Table 5. Functional feeding groups of invertebrates collected at Kent Run (KR) and Munnell Hollow (MH).

Table 6. Immatures: Community metrics and sample periods that are significantly different overall significant differences between Kent Run and Munnell Hollow (using Least Squares Means).

Table 7. Adults: Community metrics and sample periods that are significantly different overall significant differences between Kent Run and Munnell Hollow (using Least Squares Means).

Table 8. Repeated measures ANOVA of week vs. time for combined streams, giving $\mathrm{F}$ values and periods where significant differences occurred.

Table 9. Repeated measures ANOVA of week vs. time for streams considered separately, giving $\mathrm{F}$ values and periods where significant differences occurred.

Table 10. West Virginia Stream Condition Index for Kent Run and Munnell Hollow by sampling periods. 


\section{List of Figures}

Page

Figure 1. DeLorme Map - Kent Run, Greene Co., Pennsylvania 19

Figure 2. DeLorme Map - Munnell Hollow, Ryerson Station State Park 20

Figure 3. Dissolved oxygen (LSM) vs. sample period. 30

Figure 4. Hardness (LSM) vs. sample period. 34

Figure 5. Maximum temperature (LSM) vs. sample 35

Figure 6. Minimum temperature (LSM) vs. sample period. 36

Figure 7. $\mathrm{pH}(\mathrm{LSM})$ vs. sample period. $\quad 37$

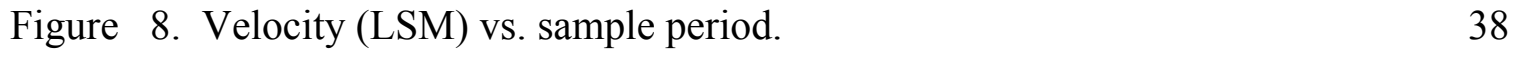

Figures $9 \mathrm{a}-\mathrm{b}$. Percentages of functional feeding groups of invertebrates collected at Kent Run and Munnell Hollow. 54-55

Figure 10. Percentages of functional feeding groups for Kent Run. 56

Figure 11. Percentages of functional feeding groups for Munnell Hollow. 57

Figure $12 \mathrm{a}-\mathrm{b}$. Total Number of Immature Taxa at Kent Run and Munnell Hollow.

Figure 13 a-b. Total Number of Immature Individuals at Kent Run and Munnell Hollow.

Figure 14 a-b. Percentage of Immature EPT Taxa at Kent Run and Munnell Hollow.

Figure 15 a-b. Percentage of Immature Collector-Filterers at Kent Run and Munnell Hollow.

Figure 16 a-b. Percentage of Immature Collector-Gatherers at Kent Run and Munnell.

Figure 17 a-b. Percentage of Immature Predators at Kent Run and Munnell Hollow. 
Figure 18 a-b. Percentage of Immature Shredders at Kent Run and Munnell Hollow.

Figure 19 a-b. Percentage of Immature Scrapers at Kent Run and Munnell Hollow.

Figure 20 a-b. Number of Immature Collector-Filterers at Kent Run and Munnell Hollow.

Figure $21 \mathrm{a}-\mathrm{b}$. Number of Immature Collector-Gatherers at Kent Run and Munnell Hollow.

Figure $22 \mathrm{a}-\mathrm{b}$. Number of Immature Predators at Kent Run and Munnell Hollow.

Figure 23 a-b. Number of Immature Shredders at Kent Run and Munnell Hollow.

Figure 24 a-b. Number of Immature Scrapers at Kent Run and Munnell Hollow.

Figure $25 \mathrm{a}-\mathrm{b}$. Number of EPT Taxa at Kent Run and Munnell Hollow.

99-100 


\section{Introduction}

Western Greene County, in which Ryerson Station State Park is located, is an area where the natural resources were the dominant factor in the development of the area and the livelihood of its people. This began with the first permanent Native American Indian settlements prior to the 1700 's that have been confirmed by archaeological digs of a village and burial site (Dufalla 1999).

The park's name originated from Fort Ryerson that was located nearby and constructed in 1792 at the order of Virginia authorities to be used primarily as a place of refuge for the pioneers from Indian raids.

Agriculture, coal, oil, and gas have played major roles in the development of this area. Although coal was mined from outcroppings early in the area's history, it was not until 1890 that coal was severed from the surface deeds and vast acreages of coal were purchased by coal companies. Oil and gas also played an important part in the development of the area. Drilling for oil and gas began in the late 1800s in western Greene County. By the early 1900s the boom was on and in 1925, 280 wells had been drilled in this part of the county. Numerous producing wells are located in the park and a large gas pipeline compression station is located directly adjacent to the park.

The park superintendent's residence has historical significance. Jessee Lazear, a prominent farmer during the Civil War, constructed the structure in 1866. It was made using hand-fired bricks from clay in the area. During excavation of the basement, Indian graves were found and reburied elsewhere on the farm. The house remained in the 
Lazear family until 1958, when it was purchased by the Commonwealth of Pennsylvania and used as the park superintendent's residence.

Land for the state park was purchased during 1958-1961 from 14 private landowners using oil and gas funds. Ronald J. Duke Lake was formed in 1960 with the construction of a dam across the North Fork of the Dunkard Fork of Wheeling Creek. Also included in the acquisition was a coal support deed for the lake area in June of 1962. Ryerson Station State Park was opened to the public in 1967 for camping, hiking, boating, picnicking, fishing, and hunting.

Headwater streams of the northern Appalachians originate in heavily canopied areas. These headwater and low order streams (Horton 1945; Strahler 1957; Moeller et al. 1979) typically follow the River Continuum Model described by Vannote et al. (1980) and Grubaugh et al. (1996). They are light-limited heterotrophic systems with rocky substrates that are fed largely by groundwater. These headwaters exhibit low-amplitude temperature and flow regimes. They are often a region of low aquatic primary production, where Production:Respiration ratios are less than 1 (Kaushik and Hynes 1971).

The major energy source is allochthonous, consisting mainly of leaf litter that enters the stream from the terrestrial system (Fisher and Likens 1973). Leaf litter is processed by macroinvertebrates of various trophic groups from coarse particulate organic matter (CPOM) into fine particulate organic matter (FPOM), and finally, into dissolved organic matter (DOM) (Vannote et al. 1980; Cummins and Wilzbach 1985; Thorp and Covich 1991; Cummins and Merritt 1996). CPOM consists of particles larger than $1 \mathrm{~mm}$ and are represented by litter accumulations consisting of leaves, needles, bark, twigs, and other 
plant parts, large woody debris (i.e. large branches and logs), and macrophytes including macroalgae and rooted and floating vascular plants. FPOM is considered to be particles between $1 \mathrm{~mm}$ and $0.005 \mathrm{~mm}$ generally composed of unattached living or detrital material including that created through physical and biological reduction of CPOM and associated microbiota. DOM consists of particles smaller than $0.005 \mathrm{~mm}$ and may enter the stream via transport from upstream, groundwater, surface runoff, precipitation (throughfall), or in situ leachate from leaves.

The predominant determinant of the macroinvertebrate species and abundance is the nature of the stream ecosystem in which they are found (Townsend 1980). First order streams originate either from precipitation runoff or from groundwater springs (Thorp and Covich 1991). The differences in slope, width, and depth of the stream as well as the physiochemical characteristics and substrate composition are determined by whether the stream originates from runoff or groundwater. Runoff streams are characteristically ephemeral with extremes in physiochemical characteristics while groundwater or spring seep streams demonstrate more continuous flow and more stable water chemistry (Thorp and Covich 1991). Most headwater streams in the Appalachian area are groundwater or spring seep streams. They only become runoff streams in the case of a major storm event.

The unidirectional flow of water and the resultant movement of mineral substances (clay, silt, sand, gravel, cobble, and boulders) produces the formation of a riffle-pool sequence (Ward 1992). This sequence results from hydrodynamic adjustments of heterogeneous substrate materials to the potential energy of flowing water (Yang 1971). Riffles are shallower, have higher gradients, coarser substrates, and higher current 
velocities than pools. In natural streams, riffles and pools alternate, with adjacent riffles generally spaced five to seven stream widths apart (Leopold et al. 1964). Riffles are erosional habitats from which fine particles are exported. Pools are depositional habitats, at least during low flow, which tend to accumulate fine bed materials (Ward 1992). Although macroinvertebrates are found in both habitats, the diversity and abundance is higher in riffles than in pools due to the greater variation in velocity, higher dissolved oxygen, and more FPOM, DOM, and periphyton (Allan 1995; Ward 1992; Thorp and Covich 1991; Cummins and Merritt 1996).

Macroinvertebrates can be classified into functional feeding groups based on the different functions they perform within aquatic ecosystems with respect to processing of nutritional resource categories. These functional feeding groups include shredders, filterer-collectors, gatherer-collectors, scrapers, and predators (Cummins and Merritt 1996). Shredders are herbivores (chewers and miners of live macrophytes) that feed on living vascular hydrophyte plant tissue, detritivores (chewers, wood borers, and gougers) whose dominant food is decomposing vascular plant tissue and wood (coarse particulate organic matter-CPOM), and gougers that excavate and feed on wood. Collectors are either collector-filterers, detritivores that are suspension feeders or collector-gatherers, or deposit (sediment) feeders. Both types of collectors feed on decomposing fine particulate organic matter (FPOM). Scrapers are herbivores that graze on mineral and organic surfaces. Their dominant food is periphyton (attached algae and associated material). Predators (engulfers) feed on living animal tissue and either ingest the whole animal (or animal parts) or they attack the prey, pierce the tissues and cells, and suck out the fluids. 
Leaf shredding macroinvertebrates (shredders) are linked to populations of collectorfilterers and collector-gatherers which utilize the FPOM they generate (Short and Maslin 1977 and Wallace et al. 1977). Shredders reduce CPOM to FPOM and dissolved organic matter (DOM) by feeding on the leaves and particularly the associated fungi and bacteria (Kaushik and Hynes 1971, Iversen 1973, Petersen and Cummins 1974, Webster 1983, Cummins 1974, Cummins and Klug 1979, Meyer and O'Hop 1983, and Cuffney et al. 1990). Shredders generate such a large volume of FPOM both because of their ability to comminute CPOM combined with their relatively low assimilation efficiencies (Berrie 1976, Vannote et al. 1980, Anderson and Sedell 1979, and Merritt et al. 1984). Calculations of detritus consumption based on shredder ingestion and production data also reveal that, whereas shredders may assimilate only a small portion of available energy (Fisher and Likens 1973), they may ingest $32-80 \%$ of the annual litter input to the stream (Webster 1983, Cummins 1971, and Webster and Patten 1979).

Fecal material produced by shredders, collectors, scrapers, and predators is another important food source for collector-filterers. The fecal material is colonized by bacteria and fungi and also fragmented by abrasion. It is then recycled primarily by collectorfilterers and "spiraled" over and over again in the system (Benke and Wallace 1980).

Shredders daily consume more than their own body weight. The process of shredders converting CPOM to FPOM results in smaller particles and also fecal material. Approximately $60 \%$ of all food ingested by shredders is converted to feces and both the food particles and fecal material go to the collectors (Cummins et al. 1989).

By a variety of mechanisms, the periphyton-bacteria-organic microlayer on substrate surfaces is scraped or browsed. Diatoms are a prominent constituent of this matrix. The 
contributions of the surface microlayer and associated bacteria, detritus, and occasionally very small invertebrates are difficult to quantify (Merritt and Cummins 1996). For example, the small caddisfly larvae (Hydroptilidae) pierce the cell walls of macroalgae and imbibe cell fluids (Cummins and Klug 1979).

Cummins' (1973) functional feeding group analysis divides invertebrate predators into engulfers and piercers, and an additional distinction can be made between sit-and-wait predators and searchers. In addition to solely remaining motionless until the prey approaches within striking range, sit-and-wait predators may also use nets (i.e. caddisfly larvae). Invertebrates may alternate between ambush and stalk (i.e. odonates) depending upon the level of hunger (Corbet 1980). When prey is abundant, locomotion is reduced. As prey density decreases, "searching" increases, and at very low prey levels, locomotion ceases to conserve energy.

Low-order streams in deciduous woodlands are known to be energetically dependent on leaf material from riparian vegetation (Fisher and Likens 1972; Hynes et al. 1974; Rabeni and Minshall 1977). Most leaves entering low-order streams travel only short distances before becoming trapped by obstructions and are essentially processed (i.e. reduced from FPOM, DOM, or mineralized) in place by a combination of biological and physical factors (Peterson and Cummins 1974; Boling et al. 1975; Iversen et al. 1982).

Biological processing of leaf material in most cases has been shown to follow the general sequence of: 1) leaching of soluble materials followed by 2) microbial colonization and conditioning and 3) invertebrate feeding (Anderson and Sedell 1979; Cummins and Klug 1979). Shredders aid in processing of microbially conditioned 
CPOM by low assimilation and high egestion of FPOM that then becomes available for collectors (Cummins 1974; Short and Maslin 1977).

The role of macroinvertebrates in detritus processing, and the relationship between detritus and benthos are reviewed by Anderson and Sedell (1979). Leaf conditioning plays an important role in the attractiveness of detritus for macroinvertebrates.

Detritivores are preferentially attracted to faster decomposing leaf types (Iverson and Madsen 1977; Kaushik and Hynes 1968). This preference is probably due to differential colonization of leaves by bacteria and, more importantly, fungi (Cummins et al. 1973; Kaushik and Hynes 1971). Bacteria and fungi increase the protein content of detritus by immobilization of nitrogen from the stream (Davis and Winterbourn 1977; Triska et al. 1975).

A variety of interrelated environmental variables determine distribution and abundance patterns of the species that collectively constitute aquatic insect communities. These variables include substrate, current, temperature, light, dissolved oxygen, and other chemical factors.

Substrate type is a major determinant of the distribution and abundance of aquatic insects (Minshall 1984). The substrate provides habitat space, food (directly, or a surface where food concentrates), and protection (i.e. from current and predators). Substrate variables of ecological importance include physical structure, organic content, stability, and heterogeneity. Uresk (1967) noted that natural stream substrate was actually a heterogeneous mixture of materials ranging from sand (less than or equal to $0.32 \mathrm{~mm}$ ) through cobble $(150 \mathrm{~mm})$. In a series of tests comparing the fauna in this mixed substrate with that in uniform substrates, he found that uniform-sized material supported fewer 
insects than the mixed. Further, more invertebrates are found on rough than smooth surfaces (Allan 1995). Thus, small woodland streams are very heterogeneous environments with invertebrate abundance even further increased by the presence of leaf packs.

"Current" refers to the velocity of moving water. It is a distance/time ratio usually measured in $\mathrm{cm} / \mathrm{sec}$. Discharge or flow refers to the amount of water moving down a channel. It is a volume/time function usually measured in cubic meters per second (Allan 1995).

Maximum water velocity in a straight section of stream channel is normally greatest at or near the surface of the water in the center of the stream with greatly diminished values along the edges and near the bottom. Ideally, velocity declines exponentially with depth, with the mean column velocity at a distance of $60 \%$ from the surface to the stream bed (Ward 1992).

A central feature of stream ecosystems is predominantly the unidirectional flow of water (Anderson and Sedell 1979). In addition to shaping the physical habitat, the current influences the kind and distribution of the fauna, and the transport and deposition of food material (Rabeni and Minshall 1977). Several studies have demonstrated the importance of current to the distribution of benthic insects (Linduska 1942; Scott 1958; Edington 1968). Current velocity affects an insect's ability to gather food (Wallace and Merritt 1980), to meet its respiratory requirements (Philipson 1954; Knight and Gaufin 1963, 1964; Jaag and Ambuhl 1964), to avoid competition and predation (Corkum and Clifford 1980; Peckarsky 1980a, 1980b; Wiley and Kohler 1981), to leave unfavorable environmental conditions (Minshall and Winger 1968; Hildebrand 1974; Corkum et al. 
1977), or to colonize favorable ones (Townsend and Hildrew 1976; Shaw and Minshall 1980; Minshall et al. 1983a). In reality, the complex features of flow (force, direction, degree of turbulence, etc.) and substratum (particle size, particle composition, stability, silt and organic content, etc.) are closely interrelated. For example, coarse substrates, open interstitial spaces, and low accumulations of organic matter predominate where the current is fast, whereas fine substrates, tightly packed particles, and large amounts of organic matter are typical of slow currents or standing waters.

Current velocity largely determines the median size and heterogeneity of the mineral substratum in streams (Leopold et al. 1964). The substratum subsequently influences the amount and particle size of allochthonous organic matter available, and this in turn affects the size of the benthic insect populations (Rabeni and Minshall, 1977; Reice, 1974, 1977).

Aquatic insects respond to the entire temperature regime, which includes absolute levels, seasonal and diel ranges, rate fluctuations, and the timing and duration of thermal events. Temperature is believed to superimpose limits on aquatic insect distribution within which the effects of substratum, current velocity, and other factors are expressed (Ulfstrand 1967; Minshall 1968; Rabeni and Minshall 1977; Vannote 1981). Sweeney and Vannote (1981) suggest that temperature affects growth and controls the endocrine system of insects, which in turn determines the ultimate size and reproductive capacity of the adults. These effects of temperature are seen to have geographic as well as withinhabitat implications for the distribution of aquatic insects (Vannote and Sweeney 1980).

The headwaters of spring-fed streams are dominated by groundwater temperatures, which are usually within $1^{\circ} \mathrm{C}$ of the mean annual air temperature of the region (Allan 
1995). Exceptions to this usual temperature regime are during ice cover, snow melt, or spates (Ward and Kondratieff 1992). Tributaries may warm or cool the main stream depending on several variables including season. Precipitation may also have a warming or cooling influence (Ward 1992). Groundwater in the soil is buffered against the effects of changing air temperature. Headwater streams fed by groundwater are at a temperature close to the surrounding soil. In the summer, this will be cooler than the air temperature and the cool water will subsequently be warmed downstream by contact with the air and solar radiation. In winter, the soil temperature near the headwaters will be warmer than the air temperature. Further downstream, these spring-fed streams may decrease in temperature in a downstream direction (Townsend 1980).

Light, in addition to influencing habitat conditions (i.e. food type and oxygen levels), may exert direct effects on aquatic insects. Many aquatic insects are believed to be negatively phototactic during most of their lives. If a light is shone on the tops of rocks during the night, the nymphs move to the lower surfaces (Elliott 1968; Higler 1975).

The main sources of dissolved oxygen are the atmosphere and photosynthesis by aquatic plants. The solubility of oxygen is a function of water temperature, pressure, and salinity. Cold water holds more oxygen at saturation than warm water.

Because molecular diffusion is a very slow process, turbulent mixing is largely responsible for maintaining saturation in well-oxygenated habitats. Upper reaches are well-oxygenated, the dissolved oxygen concentration being a function of turbulence and water temperature (Ward 1992). Turbulence of high-gradient streams ensures dissolved oxygen levels are normally near or slightly above saturation. Even slow-flowing lotic 
habitats are generally well-mixed and exhibit oxygen deficits only under special circumstances (Hynes 1970a).

Groundwater is low in dissolved oxygen and enriched in carbon dioxide due to microbial processing of organic matter as water passes through soil. Through the interaction of turbulence, aeration, and temperature, dissolved oxygen levels are quickly elevated once the groundwater enters the stream. As the water flows along the channel, dissolved oxygen can be reduced by 1) a change of turbulent, well-mixed water to less well-mixed water; 2) respiration of animals which is more conspicuous at night; and 3) decomposing organic matter such as autumn leaves or the wash-in of organic matter during floods (Ward 1992).

The interaction between oxygen and current is shown by the fact that many lotic insects exhibit dependent respiration and are unable to regulate oxygen consumption, which varies directly with the oxygen concentration of the surrounding medium (Fox et al. 1937; Knight and Gaufin 1964; Hynes 1970a).

The high oxygen requirements of lotic species, in association with a dependent-type respiration and a limited ability to increase oxygen uptake by ventilating movements, undoubtedly account for their general intolerance of low-oxygen conditions, compared with insects from lentic waters. Because most headwater streams do not exhibit oxygen gradients or deficits, insects with an evolutionary history tied to running waters have had little or no selective pressures to develop mechanisms to deal with low-oxygen conditions (Williams and Feltmate 1992).

The oxygen available to an aquatic organism is determined by three major factors (Jaag and Ambuhl 1964): 1) the amount of oxygen in the surrounding water; 2) the rate 
of oxygen uptake by the animal; and 3) the rate at which the oxygen contained within the boundary layer enveloping the animal is renewed.

The ventilatory movements performed by virtually all lentic insects, and to a lesser extent by many stream species, enhance oxygen uptake by creating currents across respiratory exchange surfaces. Lotic insects with inherent current requirements (i.e., obligate rheophiles) are unable to perform ventilatory movements, thereby relying exclusively on the flow of water to satisfy respiratory requirements. The relationship between substrate type and respiration by aquatic insects has received little study, but Ericksen (1968) demonstrated that oxygen consumption is highest in the least preferred substrate and lowest in the substrate type most frequently selected by burrowing Ephemeroptera nymphs. The higher oxygen consumption of insects on substrate may result from elevated respiration caused by stress or increased activity.

The interaction between oxygen and temperature involves the inverse relationship regarding oxygen solubility and a positive relationship between oxygen and temperature regarding the insect's oxygen requirements. Consequently, while aquatic organisms require more oxygen at higher temperatures, less is available. With insects that are "respiratory regulators", the rate of undulation of gills and bodies, in addition to the proportion of time spent in continuous undulation, also increases with rising temperature (Allan 1995).

Other stream chemical factors include acidity and water hardness. The $\mathrm{pH}$ of natural waters ranges from $<3.0$ to $>12.0$. Most unpolluted waters, however, exhibit $\mathrm{pH}$ values in the range 6.0 to 9.0 (Cole 1983) and extreme $\mathrm{pH}$ values (much below 5 or above 9) are harmful to most aquatic insects (Allan 1995). Below a pH of 6.0, certain species of 
Plecoptera and Ephemeroptera are eliminated (Harrison and Agnew 1962). In the North American Appalachians, $\mathrm{pH}$ varies inversely with dissolved carbon dioxide concentration and directly with bicarbonate concentration.

Hardness values exhibit considerable variation in freshwaters, ranging from the extremely soft waters of alpine streams situated on insoluble bedrock, to the hard waters of calcareous aquatic habitats located in limestone regions. Calcium and magnesium normally account for most of the hardness of freshwaters, although other ions such as chloride and sulfates also contribute to total hardness values. While some aquatic insects occur over a wide range of water hardness, others are largely limited to hard (calciphiles) or soft waters (calciphobes) (Macan 1961a, 1974). In general, aquatic insects, as a group, appear indifferent to normal ranges of water hardness (Macan 1974). Because of this, noninsect invertebrates are often numerically dominant in the benthos of calcareous waters, whereas insects tend to predominate in most soft-water habitats.

Studies of benthic distribution within stream substrates involve sampling the benthos with surface techniques (Cummins 1962) and concurrently measuring physical, chemical, or biological parameters that are considered important determinants of distribution (Peckarsky 1980a).

Seasonal changes in the distribution and abundance of insect species and the factors affecting distribution and abundance have been studied for several woodland streams. In a 12 month study of a Tennessee cold spring brook, Stern and Stern (1969) determined that the temperate deciduous forest imposes upon streams the ecological conditions of a low volume of soil erosion because of dense accumulations of litter on the adjacent forest floor, dense shade over the water in summer, and a heavy autumnal fall of leaves into the 
water each year. Mackay and Kalff (1969) found that the number of insect species in any one habitat varied according to apparent spatial heterogeneity of the environment, substrate suitability, and food resources.

In recent years it became necessary to develop a method to assess the benthic invertebrate groups in a stream and then subsequently monitor and compare streams (Hart 1994). Of particular interest are assessment methods that can be used quickly and inexpensively in the field to reduce sampling time and costs. Benthic invertebrates are used in $90 \%$ of the rapid-assessment programs for running water in the US. Rapid assessment approaches are characterized by the use of more than one type of measurement, or the "multimetric approach". The multimetric approach consists of defining a number of indices, or "metrics", that individually provide information on diverse biological characteristics and, when integrated, give an overall condition of the biological community (Barbour et al. 1995).

A metric is a measurable term that represents some aspect of the biological community and changes in some predictable way with increased human interference (Gibson, 1994). For a metric to be useful, it must be: (1) relevant to the biological community under investigation and also to the specified program objectives; (2) sensitive to stressors; (3) able to provide a response that can be discriminated from natural variation; (4) environmentally benign to measure in the aquatic environment; and (5) cost-effective to sample (Barbour et al. 1995).

There are three groups into which the various community metrics can be divided: richness metrics, composition metrics, and trophic metrics (Barbour et al. 1996). Richness metrics, such as the number of taxa, have become one of the most useful 
metrics to evaluate the overall health of the community and any pollution effects (Resh and Jackson 1993). The number of taxa identifies the total macroinvertebrate community and serial measurements can detect elimination of taxa from a stream system. The number of EPT (Ephemeroptera, Plecoptera, and Trichoptera) taxa is another richness metric that is widely used as part of metric assessment and environmental monitoring programs since it is very sensitive to changes in water quality (Eaton and Lenat 1991). Other richness metrics include the number of taxa for different insect orders (i. e. number of Coleoptera taxa).

Composition metrics determine the percentage of orders, families, etc. Other composition metrics include the percentage of 1 dominant taxon or 5 dominant taxa that measure the dominance of the single most abundant taxon or the 5 most abundant taxa, respectively.

Trophic metrics evaluate the percentages of the various functional feeding groups (i. e. per cent of scrapers, predators, shredders, collector-filterers, and collector-gatherers) and measure the condition of the food webs for the stream system. "Specialist" feeders such as scrapers and shredders are the more sensitive organisms and are well represented in healthy streams. "Generalists" such as collector-filterers and collector-gatherers have a broader range of acceptable food materials than specialists and thus are more tolerant to pollution that might alter availability of certain food (Cummins and Klug 1979). However, collector-filterers are thought to be more sensitive in low-gradient streams (Wallace et al. 1977).

To investigate the concept that various aspects of the environment influence species diversity and abundance, two first order streams (Kent Run and Munnell Hollow) were 
selected at Ryerson Station State Park, Greene County, Pennsylvania. Due to the close proximity of these two streams, it would be assumed that they are potentially similar both in aquatic insect species diversity and abundance as well as in the water parameters of dissolved oxygen, hardness, temperature, $\mathrm{pH}$, and current velocity. These various richness, composition, and trophic community metrics are also assumed to be similar between streams and sampling period and also between streams and time. The determination of the community metrics for the two streams throughout the one-year period will indicate, seasonally, the best time to sample in order to maximize the time and money available in a given study.

An assessment index will also be applied to the two streams. For example, in West Virginia, the West Virginia Stream Condition Index for Macroinvertebrates (Wirth, personal communication), is the assessment used. The EPA developed this index for the West Virginia Division of Environmental Protection, Division of Water Resources.

The null hypotheses are the following:

Ho (1): There is no difference in dissolved oxygen, hardness, stream temperature, $\mathrm{pH}$, or current velocity between the two streams.

Ho (2): There is no difference in species types or relative abundance of species or functional feeding group ratios between the two streams (i.e. species diversity and relative abundance are similar under similar biological conditions).

Ho 3): The seasonal distribution of each species as immatures and adults is similar between the two streams (i. e. there is no difference between sampling period and stream, ignoring time). 
Ho 4): The seasonal distribution of each species as immatures and adults is similar between the two streams (i. e. there is no difference between time and stream, ignoring sampling period). 


\section{Materials and Methods}

\section{Study Site and Location}

Two first-order streams were selected in Ryerson Station State Park, Wind Ridge, Greene County, PA (Figs. 1 and 2). The park is located in southwestern PA near the WV border. It contains 465.60 ha including a 24.80 ha lake and extends on both sides of Bristoria Road, just off PA Route 21 W, 5.00 miles from Wind Ridge, PA. Kent Run empties into North Fork Dunkard Fork of Wheeling Creek and is $5.20 \mathrm{~km}$ in length (including the permanent and intermittent portions). The intermittent portion is $1.67 \mathrm{~km}$ and the permanent portion is $3.54 \mathrm{~km}$. Kent Run is located at $39^{\circ} 52.962^{\prime} \mathrm{N}, 80^{\circ} 26.147^{\prime}$ $\mathrm{W}$; it originates at $402.90 \mathrm{~m}$ at the top of the intermittent portion and $350.40 \mathrm{~m}$ at the top of the permanent portion and empties into North Fork Dunkard Creek at $295.50 \mathrm{~m}$. The total drop for the intermittent and permanent portions is $107.10 \mathrm{~m}$ and the slope is $2.1 \%$. The total drop for the permanent portion is $54.60 \mathrm{~m}$ and the slope is $1.56 \%$. Munnell Hollow empties into North Fork Dunkard Creek and is $1.68 \mathrm{~km}$ in length. Munnell Hollow is located at $39^{\circ} 53.006^{\prime} \mathrm{N}, 80^{\circ} 25.522^{\prime} \mathrm{W}$; it originates at $405.30 \mathrm{~m}$ and empties into North Fork Dunkard Creek at $294.60 \mathrm{~m}$. The total drop is $110.70 \mathrm{~m}$ and the slope is $6.99 \%$. Kent Run is a south facing slope and gets more direct sunlight, while Munnell Hollow is north facing and gets much less sunlight. Substrate also varies between streams, with Kent Run having greater areas of sand and Munnell Hollow having more bedrock areas. 


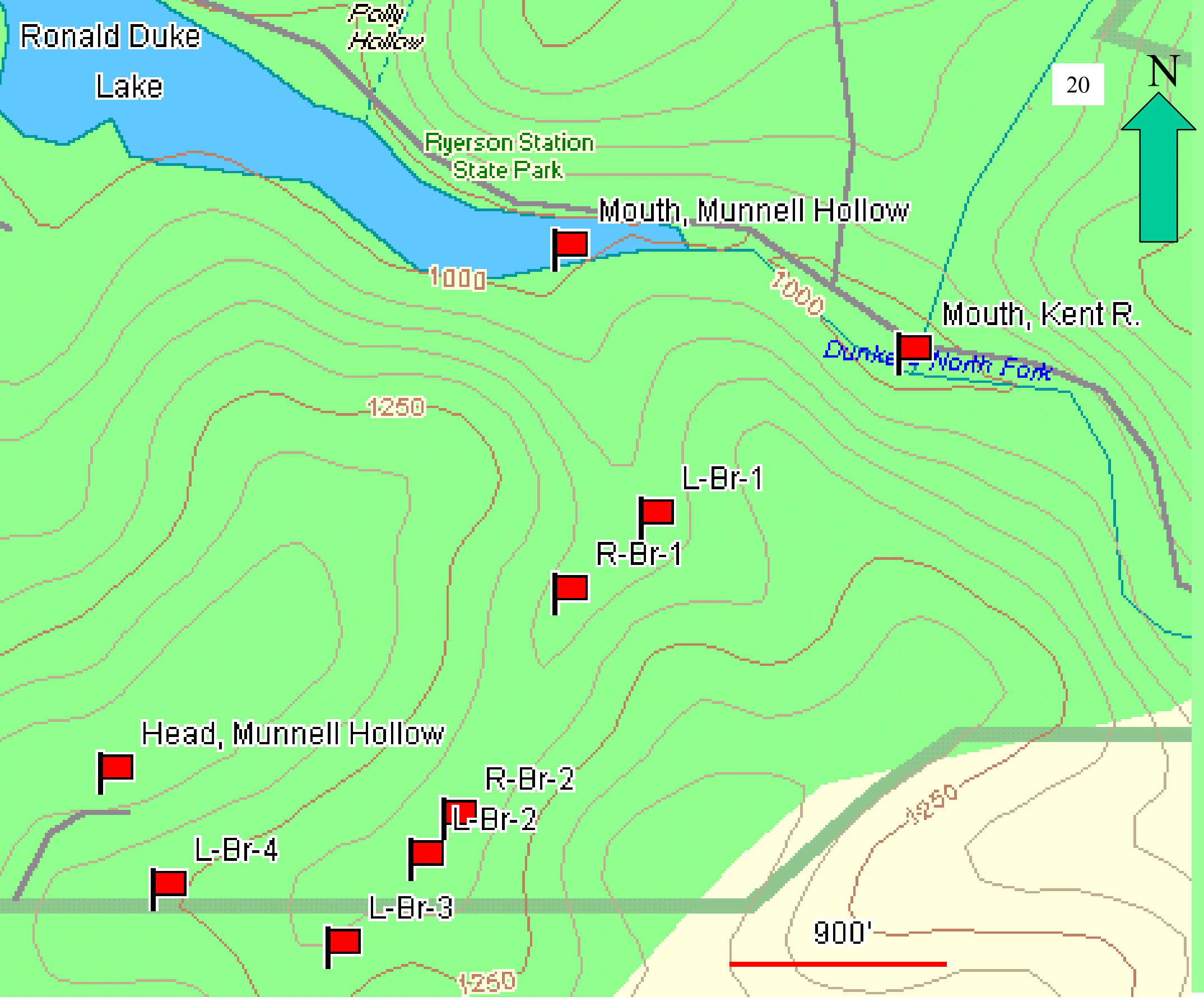

Figure 2. DeLorme Map - Munnell Hollow, Ryerson Station St. Park 


\section{Sampling}

The two streams, Kent Run and Munnell Hollow, were sampled biweekly from May, 1999 through April, 2000 for a total of 26 sampling periods. All samples from both streams were taken on the same day in the same order for each sampling period. The simple random sample statistical approach was used (Cochran 1953 and Hansen et al. 1953). Macan (1961b) has referred to this sampling method as the biological approach, since factors typical to each species are sought by grouping the data obtained from random collections. A grid was superimposed on the study area and intercepts were numbered. Then, by using a table of random numbers, each stream had three $50 \mathrm{~m}$ sections assigned before going out into the field, in order to minimize sample variance (Egglishaw, 1964). The sampling for that period was conducted on those specific $50 \mathrm{~m}$ sections.

The three day sequence of work during each biweekly sampling period was identical. On Day One, the maximum-minimum thermometers (Taylor Indoor/Outdoor Maximum/Minimum Thermometer \#5460, Fletcher, NC) were suspended by a rope in the stream and attached to stakes placed into the stream bank. Also on Day One, adult emergence traps (\#2828, Bioquip, Gardenia, CA) were put into position, one in each of the three sections of each stream. The traps were suspended from trees above the stream and were placed with the two sides directly above the water level or slightly into the water, thereby sampling insects emerging from a known area. The emergence traps measure 2 meters square and $2.4 \mathrm{~m}$ high. The front and back are cut $0.4 \mathrm{~m}$ shorter than the sides to allow water to flow through without obstruction. Emergence traps were placed so that trap openings were parallel to the stream. A $1.2 \mathrm{~m}$ opening with a Velcro 
closure on the front (upstream side) allows the user to enter the trap and refasten the opening from inside. Sufficient headroom allows the user to collect newly emerged insects with a small net, forceps, or maneuver them to fall directly into the alcohol collecting jars. The trap peak is supported by a 2 " steel ring and heavy fabric loops are located at each corner to be suspended by ropes and stakes to keep the emergence trap open to the desired position. The mesh size is $20 \times 20$ mesh Lumite screen with $956 \mu \mathrm{m}$ openings.

On Day Two, the following water tests were done at the three sampling sites on each stream, typically in a run area. These tests included pH (Hanna Instruments pHep1 pocket-sized $\mathrm{pH}$ meter, San Jose, CA, with a range of 0.0 to $14.0 \mathrm{pH}$ ); dissolved oxygen (Chemetrics Dissolved Oxygen Chemets Kit $-\mathrm{K}-7512$, Calverton, VA with a range of 1 to12 ppm); velocity (General Oceanics Inc. Mechanical Flowmeter Model 2030R, Miami, FL); hardness (Chemetrics Total Hardness Titrets Kit - K - 4502, Calverton, VA with a range of 2 to $20 \mathrm{ppm})$; and maximum and minimum temperature $\left({ }^{\circ} \mathrm{C}\right)$.

Also on Day Two, benthic macroinvertebrates were sampled using a Wildco Surber Stream Bottom Sampler \#12-B32. This sampler is designed for shallow streams less than $460 \mathrm{~mm}$ (18") deep. The sampler consists of two pivoting solid brass frames and lockable brace latches that hold the frames at right angles to each other when sampling. Both the upright frame and the base frame support the Nitex net. The open base, which rests on the stream bottom, encloses an area of $305 \mathrm{~mm}$ x $305 \mathrm{~mm}$ (12” x 12”). The Nitex net mesh is $1000 \mu \mathrm{m}$.

During each of the 26 sampling periods, nine Surber samples were collected from each stream - three from each of the $50 \mathrm{~m}$ stream sections. Of the three, one was 
collected from the riffle area (which typically had detritus piles of leaves, branches, buds, or twigs), one from the pool area (topographic depressions in the stream bottom where the velocity is least), and one from the run area (located between the riffle and pool area and topographically at a higher point of the channel than the pools). The selection of which pool, riffle, and run would be sampled at each period was done by counting the number of each in the $50 \mathrm{~m}$ section and then doing a random number drawing for each of the three habitats.

When in use, the sampler was firmly placed on the stream bottom and the substrate within the frame boundary was stirred up with a trowel. The down-stream current washed the detritus, lighter sediments, and invertebrates into the net (Herbst, 1979). The net was emptied by turning it inside out and picking it clean. All detritus and invertebrates were placed in labeled plastic bags and frozen until sorted and identified. For this, the contents of each bag was placed in a $13 \frac{1}{2} "$ × $10^{\prime \prime}$ bright white polyethylene tray (Bioquip \#1426B) and the animal contents were sorted and placed in vials of $70 \%$ ethanol. They were later identified to species or genera, if species keys were not available.

On Day Three, the adults were collected from the adult emergence traps that had been in place for $48 \mathrm{hrs}$. This allowed for capture of insects emerging during both the day and the night (Hauer and Lamberti, 1996). The adults were later keyed to species or genera, if species keys were not available. The keys used in the identification of the adult and immature insects are listed in Appendix I.

Identifications were confirmed by the following entomologists: Diptera (Simuliidae) adults and pupae by Dr. James Amrine, Jr.; West Virginia University; Division of Plant 
and Soil Sciences; Morgantown, West Virginia; Ephemeroptera adults by Dr. Boris Kondratieff; Colorado State University; Department of Bioagricultural Sciences and Pest Management; Fort Collins, CO 80523; Collembola, Ephemeroptera nymphs, Odonata nymphs and adults, Plecoptera nymphs and adults, Hemiptera nymphs and adults, Megalopetra and Neuroptera larva and adults, and Trichoptera larvae and adults by Mr. Robert Lake, retired, University of Delaware; and Diptera larvae and adults by Dr. Chen Young; Associate Curator; Section of Invertebrate Zoology; Carnegie Museum of Natural History; 4400 Forbes Avenue; Pittsburgh, PA 15213.

Voucher specimens from the study will be deposited in the West Virginia University Arthropod Collection, Plant and Soil Sciences, West Virginia University. Morgantown, WV.

Taxa were then classified into functional groups based on their modes of feeding (collector-gatherer, collector-filterer, scraper, shredder, and predator) (Merritt and Cummins, 1996). The percentages of the functional feeding groups shredder, collector, scraper, and predator were determined and compared for the River Continuum Concept (Vannote et al. 1980), Kent Run, and Munnell Hollow.

Thirty- two community metrics were determined for immature and 35 for adult collections. Both the number of EPT (Ephemeroptera, Plecoptera, and Trichoptera) taxa and percentage of EPT taxa were evaluated among others. These metrics are used because they form a foundation for an integrated analysis of the biotic condition of the stream (Barbour et al. 1999).

Statistical analyses of the water parameters and taxa were done using a specific multivariant analysis called a repeated measures ANOVA, which uses data sets with multiple 
measurements of a variable (SAS, 1996). The same level of significance was used for all statistical analysis procedures $(<0.001)$. In most experiments, as in the Ryerson study, the measurements of the variables are made over time. A repeated measures is a completely randomized experimental design with data collected in a sequence of equally spaced points in time. The treatments have been assigned to a variable (i.e. dissolved oxygen, $\mathrm{pH}$, number of Plecoptera, percentage of scrapers) and data are collected at a sequence of times on each variable.

In repeated measures experiments, interest centers on: (1) how treatment means change over time and (2) how treatment differences change over time. The community metrics selected are composed of representative orders and functional feeding groups present in Kent Run and Munnell Hollow. The procedure for calculation of numbers and percentages of each metric is a multimetric approach routinely used for Rapid Bioassessment Protocols (RBPs) (Barbour et al. 1999). Least Squares Means values were used to combine the three values for each stream at each sampling period. This single value was then used in the repeated measures ANOVA calculations.

Three different repeated measures ANOVA analyses were done on the data collected. The first was on the six water parameters: dissolved oxygen, hardness, maximum temperature, minimum temperature, $\mathrm{pH}$, and velocity.

On the invertebrate data, the first comparison evaluated the interaction between week (sampling period) and site (stream) in order to determine if there were significant differences between the two streams at each of the sampling periods for 32 immature and 35 adult community metrics. A comparison of the means for the combined streams, ignoring time, produced the cross-comparison of week versus site using the repeated 
measures ANOVA. Note that some of the less common taxa were eliminated from the data analysis because they carry little information in the data matrix and create noise, making interpretation difficult (Faith and Norris 1989).

The second comparison on the invertebrate data, involved the interaction between week (sampling period) and time (time of year), ignoring site (stream). Data were analyzed combining both streams and then comparing the two streams. A repeated measures ANOVA was calculated on the means for each week in order to determine if there was a significant difference depending on the time of year samples were collected. Tukey's test indicates which weeks were significantly different. The potential of this type of analysis is to evaluate where the metrics are higher than at other times of the year in order to select sampling periods that give the best evaluation of the stream. It may be a narrow period of time or some "window" of time during the year.

The West Virginia Stream Condition Index for Macroinvertebrates is based on six metrics: number of total taxa, number of EPT taxa, percentage of EPT, percentage of the two dominant taxa, and the Hilsenhoff Biotic Index (HBI) to family level (an average tolerance value to organic pollution). The index values run from 0 to 100 . Streams are considered not impaired with values above 68.0 , impaired with values below 60.6 , and a gray area from 60.6 to 68.0. The indices were calculated for Kent Run and Munnell Hollow at each sampling period. 


\section{Results}

In general, water quality parameters varied between Kent Run and Munnell Hollow. Dissolved oxygen, maximum temperature and minimum temperature were overall higher at Munnell Hollow and hardness, pH, and velocity were overall higher at Kent Run. A total of 5,462 invertebrates were collected from both streams during this study, and Kent Run had a greater number than Munnell Hollow. For both immature and adult community metrics, Kent Run was significantly higher with regard to number of collector-filterer taxa and percentage of collector-filterers, number of collector-gatherer taxa and percentage of collector-gatherers, and percentage of Odonata. Munnell Hollow was significantly higher with regard to number of Ephemeroptera taxa and percentage of Ephemeroptera, number of EPT taxa, number of shredder taxa and percentage of shredders, percentage of predators, and percentage of Diptera. Results for seasonal aspects of community metrics for immatures show an optimal time of periods 26,25 , and 1 (April 10 - May 14) to monitor community metrics.

\section{Water Parameters}

The calendar dates for sampling periods 1 through 26 are listed in Table 1; dates ranged from May 13, 1999 through April 27, 2000.

\section{Dissolved Oxygen}

Dissolved oxygen (in ppm) at Kent Run ranged from a low of $3.00 \mathrm{ppm}$ at period 7 to a high of $12.00 \mathrm{ppm}$ at period 26 (Fig. 3). At Munnell Hollow, dissolved oxygen ranged from a low of $3.33 \mathrm{ppm}$ at period 10 to a high of 12.0 at period of 26 . The minimum 
recorded concentration of dissolved oxygen occurred during periods 10 and 11 when the volume of water was low and fallen leaves choked portions of the stream. Significant differences between the streams occurred during periods $2,4,6,7,8$, 9, and 15 with dissolved oxygen being significantly higher at Munnell Hollow $(\mathrm{p}<0.001)$ during five of those seven periods. Table 1 shows sampling period and calendar dates for Kent Run and Munnell Hollow. 
Table 1. Sampling period and calendar dates for Kent Run and Munnell Hollow

Sample Period

Calendar Date

1

2

3

4

5

6

7

8

9

10

11

12

13

14

15

16

17

18

19

20

21

22

23

24

25

26
May 12-14, 1999

May 24-26, 1999

June 7-11, 1999

June 21-25, 1999

July 5-9, 1999

July 19-21, 1999

July 26-28, 1999

August 16-18, 1999

August 30-September 1, 1999

September 13-15, 1999

September 27-29, 1999

October 11-13, 1999

October 25-27, 1999

November 8-10, 1999

November 22-24, 1999

December 6-8, 1999

December 20-22, 1999

January 3-5, 2000

January 17-19, 2000

January 30-Febuary 1, 2000

February 14-16, 2000

February 28-March 1, 2000

March 13-15, 2000

March 27-29, 2000

April 10-12, 2000

April 24-26, 2000 


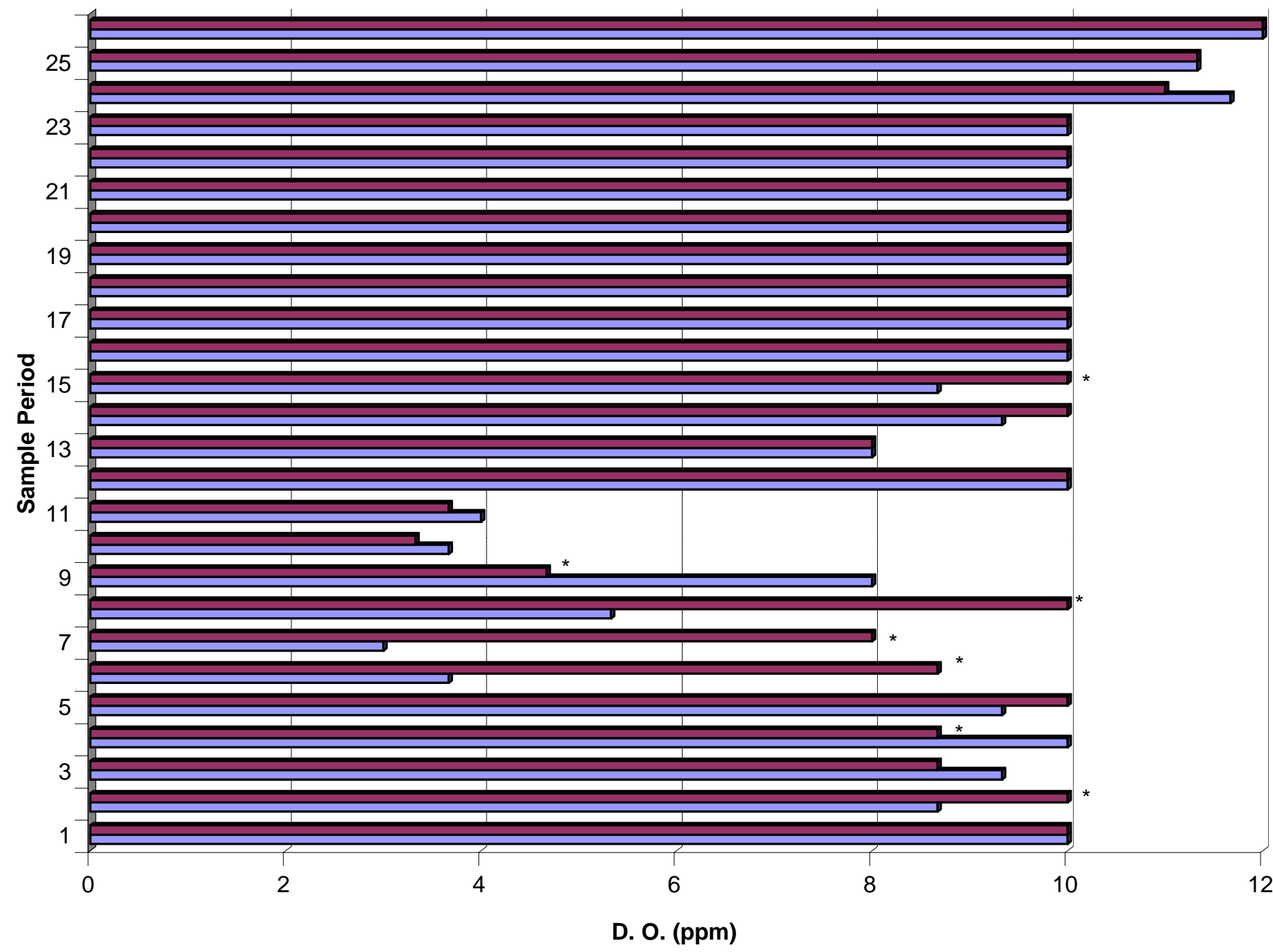

$\square$ Munnell Hollow

$\square \quad$ Kent Run

Figure 3. Dissolved Oxygen (LSM) vs. Sample Period (Significant differences in periods 2, 4, 6, 7, 8, 9, and 15, as indicated by asterisk for Kent Run and Munnell Hollow) 


\section{Hardness}

At Kent Run, hardness (in ppm or $20 \mathrm{mg} / \mathrm{L} \mathrm{CaCO} 3$ ) ranged from a low of $15.33 \mathrm{ppm}$ at period 10 to a high of $17.67 \mathrm{ppm}$ during periods 8, 13, 15, 21, and 24 (Fig. 4). At Munnell Hollow, hardness ranged from a low of 15.00 ppm during periods 12, 15, 19 20,21 , and 24 to a high of 17.33 during periods 3,4 , and 26 . Significant differences in hardness between the two streams occurred at all sampling periods with the exception of periods $1,2,3$, and 26. Hardness was significantly higher in Kent Run $(\mathrm{p}<0.001)$ at 20 of the remaining 22 periods except for periods 4 and 10 where hardness was higher at Munnell Hollow.

\section{Maximum Temperature}

Maximum water temperature (in ${ }^{\circ} \mathrm{C}$ ) at Kent Run ranged from a minimum of $1.33^{\circ} \mathrm{C}$ at period 17 to a maximum of $23.67^{\circ} \mathrm{C}$ at period 8 (Fig. 5). Maximum temperature at Munnell Hollow ranged from a low of $3.00^{\circ} \mathrm{C}$ at periods 18 and 20 to a high of $24.67^{\circ}$ $\mathrm{C}$ at period 7. Significant differences between the streams occurred during periods 6,9 , and 23 with Kent Run having significantly lower temperatures at periods 6 and $23(\mathrm{p}<$ $0.001)$.

\section{Minimum Temperature}

Errors were made in determining minimum temperature. Readings given for minimum water temperature (Fig. 6) in ${ }^{\circ} \mathrm{C}$ at Kent Run ranged from $-7.00^{\circ} \mathrm{C}$ at period 20 to $20.67^{\circ} \mathrm{C}$ at period 8. At Munnell Hollow, minimum temperature ranged from a low of $-5.00^{\circ} \mathrm{C}$ at periods 19 and 20 to $22.67^{\circ} \mathrm{C}$ at period 7 . Since fresh water 
temperatures normally cannot go below $0^{\circ} \mathrm{C}$, it appears that the air temperature lowered the temperature reading of the thermometer that was mistakenly not reset under water. Therefore, the minimum temperature readings are questionable. In Fig. 6, all below zero readings were indicated at $0^{\circ} \mathrm{C}$. During periods 19,20 , and 21 , ice formed at the sides of the stream, often developing into ice bridges on which snow accumulated. This occurred consistently at Kent Run, but only intermittently at Munnell Hollow. Significant differences in minimum temperature occurred between the streams during periods $5,6,7,20$, and 25 and in all five periods, minimum temperature was significantly lower in Kent Run $(\mathrm{p}<0.001)$.

pH

For Kent Run, pH values (Fig. 7) ranged from a low of 5.57 at period 10 to a high of 9.10 during sampling periods 20, 21, and 22. Values for Munnell Hollow varied from a minimum of 5.90 at period 11 to a maximum of 8.77 during period 20. Significant differences in $\mathrm{pH}$ occurred between the streams during 12 of the 26 periods with Kent Run having significantly higher $\mathrm{pH}$ at 10 of these periods: 1, 2, 14, 16, 18, 22, 23, 24, 25, and 26 ( $\mathrm{p}<0.001)$. pH values for Kent Run were above 8.5 for periods 17 through 26 . Periods 1 through 9 and 12 through 16 were above 7.0, with periods 10 and 11 dropping to a $\mathrm{pH}$ of between 5.5 and 6.0. Munnell Hollow had $\mathrm{pH}$ values over 8.0 for periods 19 through 26. The lowest values were at periods 11,16 , and 18 . 


\section{Velocity}

Velocity (in $\mathrm{cm} / \mathrm{sec}$ ) at Kent Run ranged from a minimum of $0.00 \mathrm{~cm} / \mathrm{sec}$ during periods $4,6,7,8,9,10,11$, and 13 to a maximum of $52.60 \mathrm{~cm} / \mathrm{sec}$ during period 14 (Fig. 8). Velocity at Munnell Hollow ranged from a low of $0.00 \mathrm{~cm} / \mathrm{sec}$ during periods 4,9 , 10,11 , and 13 to a maximum of $35.90 \mathrm{~cm} / \mathrm{sec}$ during period 2 . Significant differences in velocity occurred between the streams during periods $1,2,14,15,16,17$, and 21 with Kent Run consistently having the higher velocity $(\mathrm{p}<0.001)$.

A summary of significant differences in measured parameters as determined by analysis of variance is given in Table 2 . Hardness, $\mathrm{pH}$, and velocity were generally higher at Kent Run while dissolved oxygen and maximum and minimum temperatures were generally higher at Munnell Hollow. The number of periods at which significant differences occurred for each water parameter is also given in Table 2. Hardness and pH were generally different between the streams (in 22 and 12 sampling periods respectively). Both were typically higher in Kent Run.

Velocity measurements were conducted by Dr. James W. Amrine on Saturday, 16 March, 2002 at both Kent Run and Munnell Hollow. The rate of flow was 1.29 cubic $\mathrm{m} / \mathrm{sec}$ for Kent Run and 0.38 cubic m/sec for Munnell Hollow. The ratio of flow for Kent Run/Munnell Hollow was 3.39. 


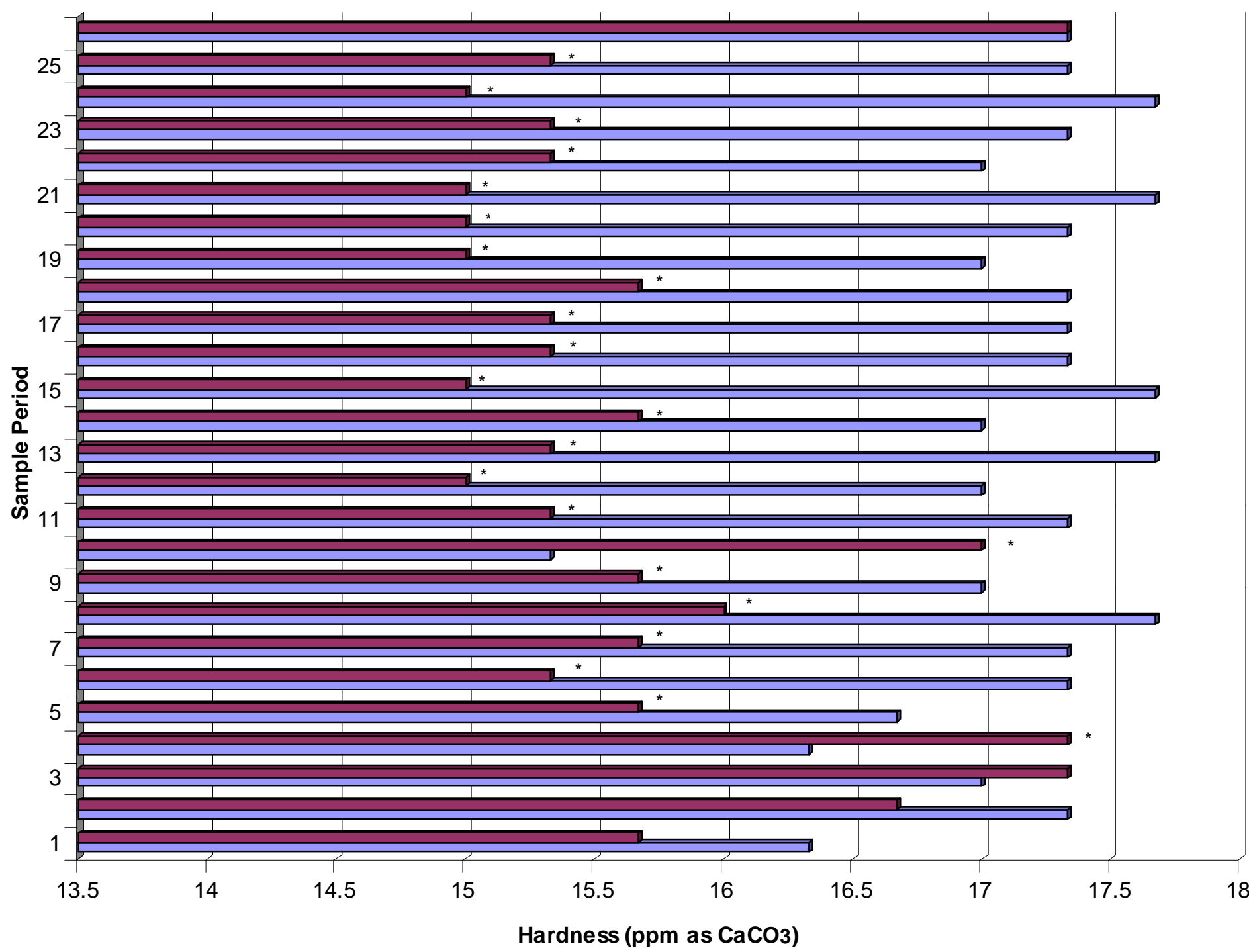

$\square$ Munnell Hollow $\square$ Kent Run

Figure 4. Hardness (LSM) vs. Sample Period (Significant differences in all periods except 1, 2, 3, and 26, as indicated by asterisk for Kent Run and Munnell Hollow) 


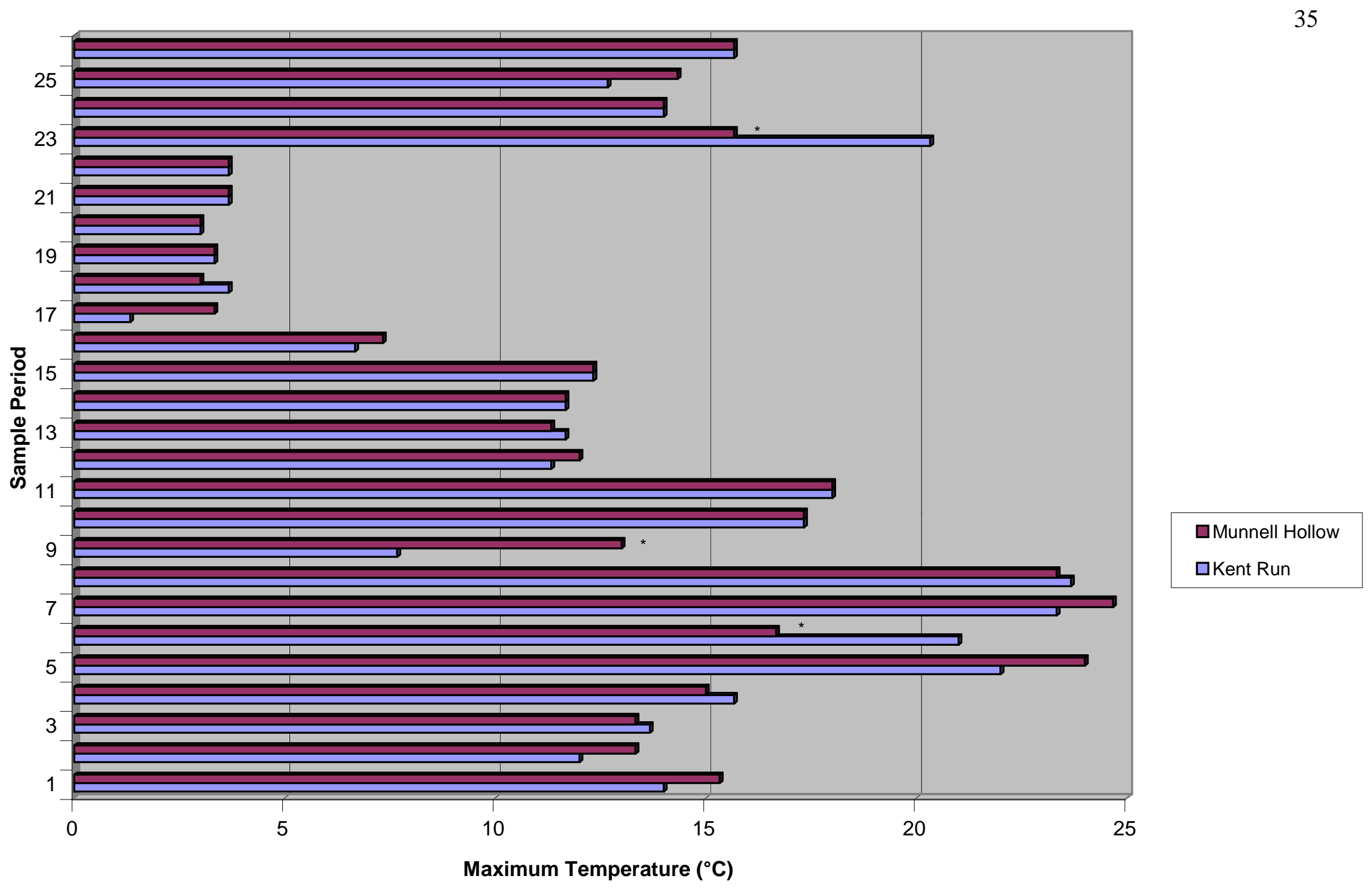

Figure 5. Maximum Temperature (LSM) vs. Sample Period (Significant differences in periods 6, 9, and 23, as indicated by asterisk for Kent Run and Munnell Hollow) 


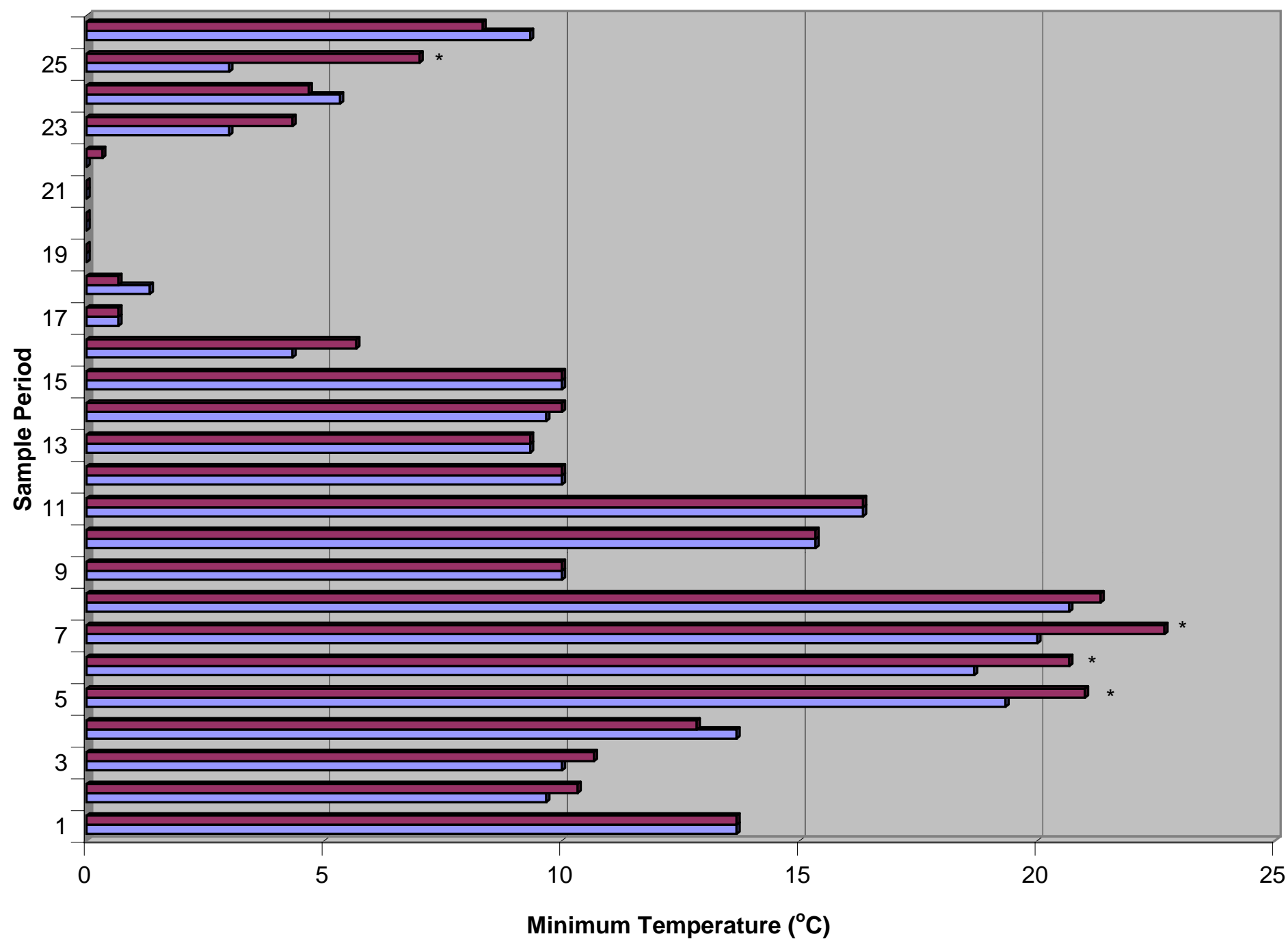

$\square$ Munnell Hollow $\square$ Kent Run

Figure 6. Minimum Temperature (LSM) vs. Sample Period ( Significant differences in periods 5, 6, 7, and 25, as indicated by asterisk for Kent Run and Munnell Hollow) 


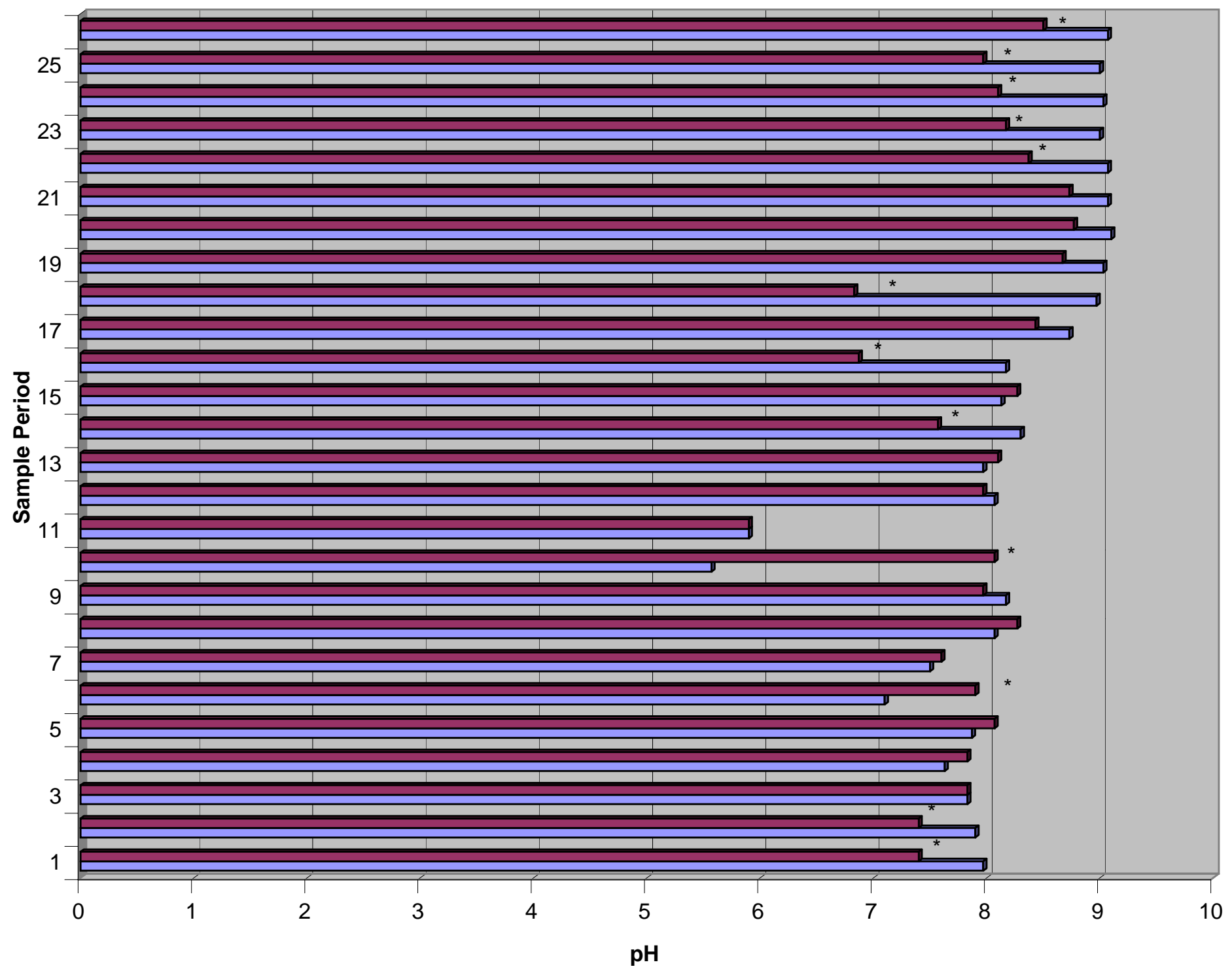

口Munnell Hollow

$\square$ Kent Run

Figure 7. pH (LSM) vs. Sample Period (Significant differences occurred at periods 1, 2, 6, 10, 14, 16, 18, 22, 23, 24, 25, 26, as indicated by asterisk for Kent Run and Munnell Hollow) 


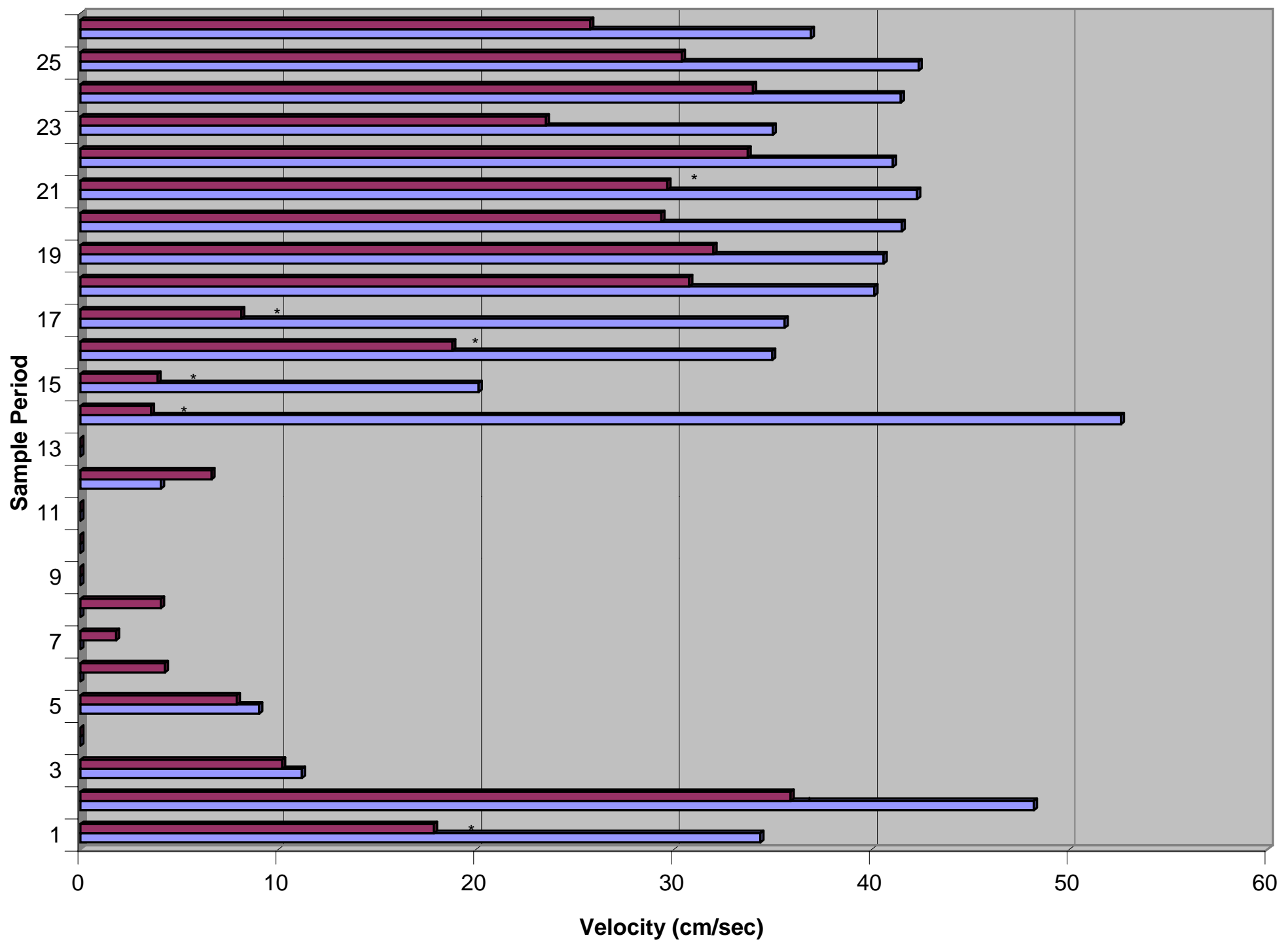

aMunnell Hollow

口Kent Run

Figure 8. Velocity (LSM) vs. Sample Period (Significant differences in periods 1, 2, 14, 15, 16, 17, 21, as indicated by asterisk for Kent Run and Munnell Hollow) 
Table 2. Summary of Comparison (ANOVA) of Water Parameters between Kent Run and Munnell Hollow

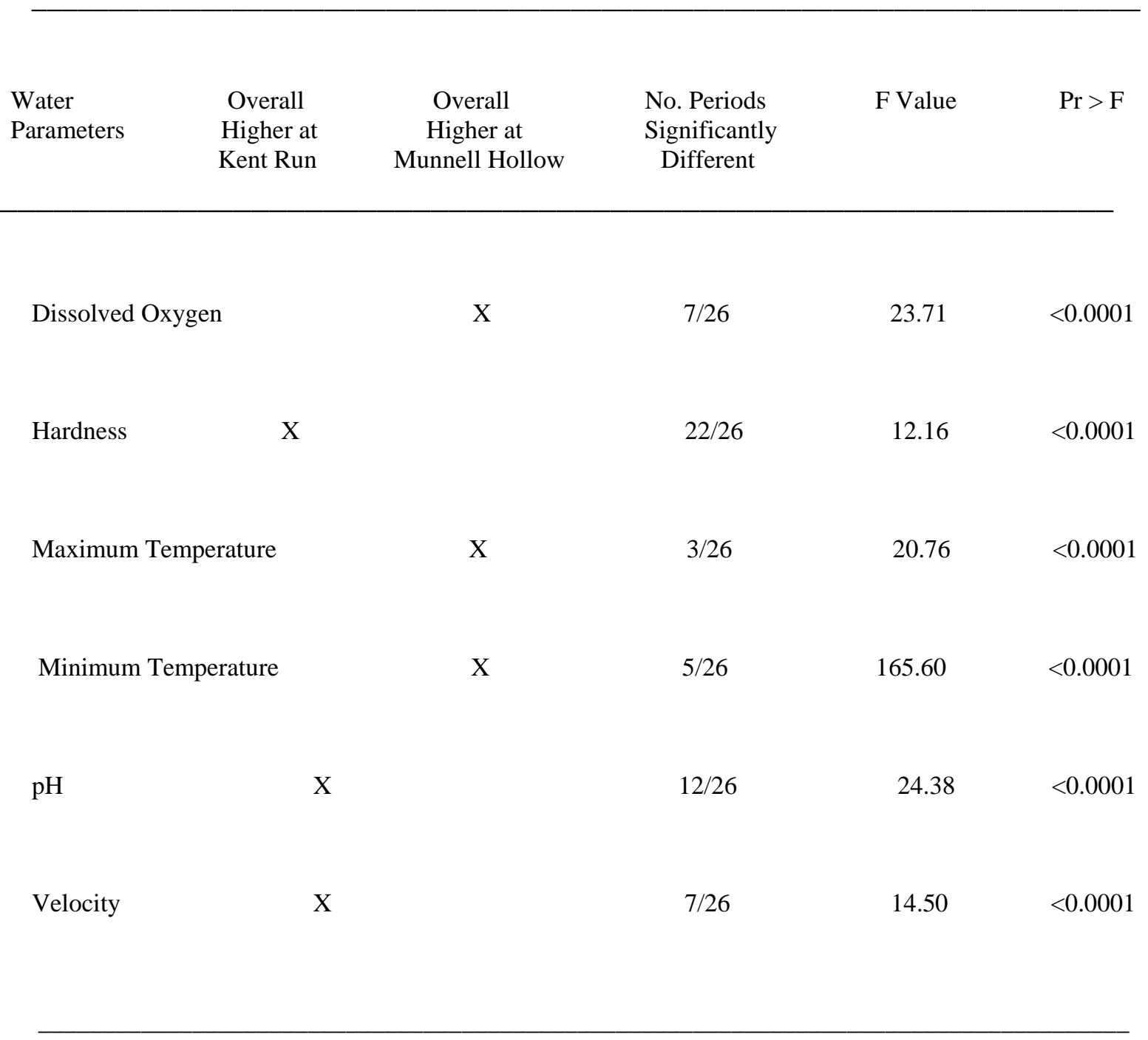


A major drought occurred in the summer of 1999. With regard to impact on stream flow, the drought effects became particularly evident by 21 June, 1999 during period 4 and continued through 29 September, 1999 at period 11. During this time, there were stretches in each stream (sometimes up to $30 \mathrm{~m}$ in length) that had no visible water. In addition, there were occasional pools present between the dry areas. Very few areas with continuous flow were noted. Also during this time, Kent Run had more water than Munnell Hollow. When sampling began on 11 October, 1999 for period 12, continuous water flow at both Kent Run and Munnell Hollow had been restored. 


\section{Invertebrates - Immatures}

A total of 5,462 invertebrates were collected from both streams during this study, 2,439 adults and 3,023 immatures (Table 3). Kent Run had 3,299 individuals, 1,166 adults and 2,133 immatures. Of the 2,163 total individuals at Munnell Hollow, 1,273 were adults and 890 were immatures. Period 1 (May 12-May 14, 1999) and period 26 (April 24-26, 2000) had the greater number of individuals at Kent Run, with 450 and 948, respectfully. Munnell Hollow had the greatest number of individuals (281) at period 26.

The total number of taxa collected in both streams was 180 (Table 4). Of these, there were 121 adult taxa and 88 immature taxa. Kent Run had a total of 137 taxa: 90 adults and 62 immatures. Munnell Hollow had the same number of total taxa as Kent Run (137) as well as total adult taxa (90) but the total count of immature taxa was 67. Appendix 2 lists invertebrates collected by order, family, genus and/or species (some non-aquatic invertebrates were only identified to family), and the stream from which they were collected. Period 26 had the greatest number of taxa with 23 taxa at Kent Run and 27 at Munnell Hollow. 
Table 3. Total number of individuals, total present as adults, and total present as immatures at Kent Run and Munnell Hollow for each sample period

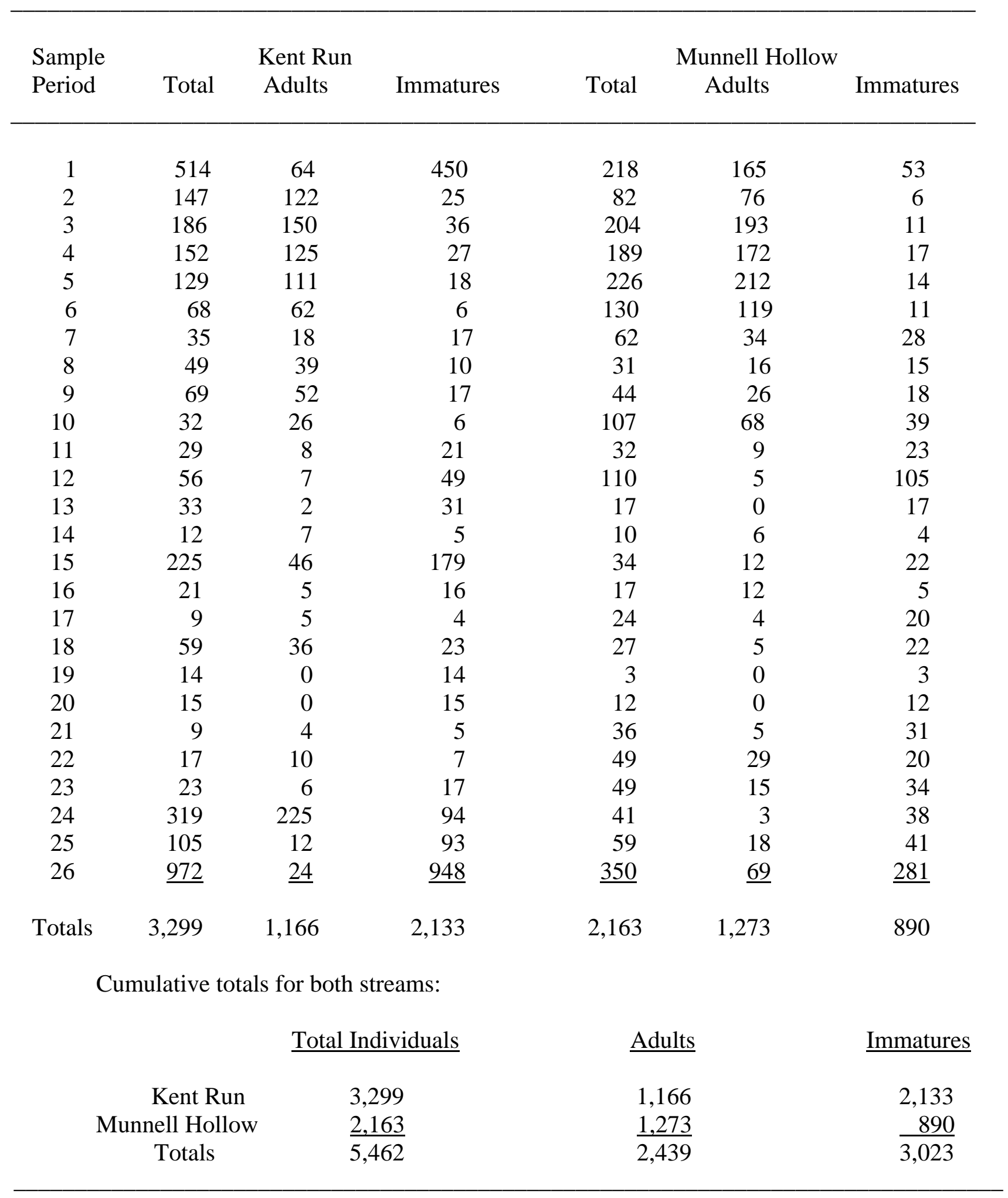


Table 4. Total number of taxa and totals collected as adults and immatures at Kent Run and Munnell Hollow for each sample period.

\begin{tabular}{|c|c|c|c|c|c|c|}
\hline \multirow{2}{*}{$\begin{array}{c}\text { Sample } \\
\text { Period }\end{array}$} & \multicolumn{3}{|c|}{ Kent Run } & \multicolumn{3}{|c|}{ Munnell Hollow } \\
\hline & Total & Adults & Immatures & Total & Adults & Immatures \\
\hline 1 & 21 & 14 & 10 & 34 & 24 & 12 \\
\hline 2 & 31 & 26 & 9 & 26 & 24 & 4 \\
\hline 3 & 33 & 28 & 6 & 36 & 31 & 6 \\
\hline 4 & 36 & 28 & 9 & 29 & 24 & 5 \\
\hline 5 & 27 & 17 & 10 & 22 & 18 & 5 \\
\hline 6 & 13 & 9 & 4 & 22 & 16 & 6 \\
\hline 7 & 14 & 7 & 7 & 14 & 8 & 6 \\
\hline 8 & 11 & 7 & 4 & 8 & 6 & 3 \\
\hline 9 & 18 & 12 & 6 & 12 & 6 & 5 \\
\hline 10 & 11 & 8 & 3 & 14 & 9 & 5 \\
\hline 11 & 12 & 5 & 7 & 9 & 4 & 5 \\
\hline 12 & 9 & 4 & 6 & 14 & 2 & 11 \\
\hline 13 & 6 & 1 & 5 & 5 & 0 & 5 \\
\hline 14 & 7 & 4 & 3 & 4 & 3 & 1 \\
\hline 15 & 8 & 7 & 4 & 9 & 4 & 5 \\
\hline 16 & 5 & 2 & 3 & 6 & 3 & 3 \\
\hline 17 & 5 & 1 & 4 & 8 & 1 & 7 \\
\hline 18 & 10 & 3 & 7 & 10 & 3 & 7 \\
\hline 19 & 5 & 0 & 5 & 3 & 0 & 3 \\
\hline 20 & 7 & 0 & 7 & 5 & 0 & 5 \\
\hline 21 & 5 & 1 & 4 & 8 & 1 & 7 \\
\hline 22 & 6 & 1 & 5 & 10 & 3 & 7 \\
\hline 23 & 10 & 3 & 7 & 17 & 3 & 14 \\
\hline 24 & 12 & 1 & 12 & 9 & 2 & 7 \\
\hline 25 & 20 & 2 & 18 & 14 & 5 & 10 \\
\hline 26 & 24 & 5 & 23 & 33 & 8 & 27 \\
\hline \multicolumn{7}{|c|}{ Cumulative totals for both streams: } \\
\hline & & \multicolumn{2}{|c|}{$\underline{\text { TOTAL TAXA }}$} & $\underline{\text { ADULTS }}$ & \multicolumn{2}{|c|}{$\underline{\text { IMMATURES }}$} \\
\hline \multicolumn{3}{|c|}{ Kent Run } & 137 & 90 & \multicolumn{2}{|c|}{62} \\
\hline \multicolumn{3}{|c|}{ Munnell Hollow } & $\underline{137}$ & 90 & \multicolumn{2}{|c|}{$\underline{67}$} \\
\hline \multicolumn{3}{|c|}{ Both streams } & & 121 & \multicolumn{2}{|c|}{88} \\
\hline
\end{tabular}


The functional feeding groups of invertebrates collected at Kent Run and Munnell Hollow are listed in Table 5. As with Appendix 2, they are listed by order, family, genus and/or species when possible. Some non-aquatic invertebrates were only identified to family. Also listed is the stream(s) where they were collected.

Figures $9 \mathrm{a}$ and $9 \mathrm{~b}$ illustrate the percentages of functional feeding groups of invertebrates collected at Kent Run and Munnell Hollow. Collector-filterers were most abundant at periods 1, 6-7, and 11-12. They were not found in periods 14 through 21 . Collectorgatherers were most abundant during periods 1 through 3 and 24 through 26 . They were not present during periods 3 through 7 . Predators were represented throughout the entire year and they were present in each sampling period at least in one of the streams. Shredders were most abundant during periods 14 and 15 which corresponded with the period after autumn leaf input. Scraper percentages were greater during periods 21 through 26 in late winter and early spring.

The typical relationship for first through third order streams between shredders: collectors: scrapers: and predators according to the River Continuum Concept (Vannote et al. 1980) is $37 \%(+/-2 \%): 45 \%(+/-3 \%): 6 \%(+/-5 \%): 12 \%(+/-2 \%)$, respectively. The actual percentages determined for Kent Run are 20\%: 31\%: 12\%: 37\% (Figure 10) and for Munnell Hollow: 20\%: 30\%:11\%: 39\% (Figure 11). 
Table 5. Functional feeding groups of invertebrates collected at Kent Run (KR) and Munnell Hollow (MH).

Classification

Genus/Species

KR

MH

\section{Predators}

Phylum Arthropoda - Class Insecta

Odonata

Coenagrionidae

Chromagrion conditum (Hagen)

$\mathrm{X}$

Cordulegasteridae

Cordulegaster obliquus (Say)

Cordulegaster sayi Selys

Cordulegaster maculatus Selys

$\mathrm{X}$

$\mathrm{X}$

$X$

X

Aeschnidae

Epiaesehna heros (Fabricius)

Boyeria vinosa (Say)

X

Gomphidae

Lanthus parvulus (Selys)

Lanthus albistylus (Hagen)

X

Calopterygidae

Calopteryx maculata Leach

Calopteryx maculatum Beauvois

$\mathrm{X}$

$\mathrm{X}$

$\mathrm{X}$

$\mathrm{X}$

X

Plecoptera

Chloroperlidae

Utaperla gaspesiana Harper and Roy

$\mathrm{X}$

Sweltsa mediana (Banks)

Alloperla banksi Frison

Haploperla brevis (Banks)

Suwallia marginata (Banks)

Alloperla sp. Banks

$\mathrm{X}$

$\mathrm{X}$

$\mathrm{X}$

$\mathrm{X}$

Perlodidae

Isoperla similis (Hagen)

Diploperla duplicata (Banks)

Cultus decisus (Walker)

X

$\mathrm{X}$

Isoperla sp. Banks

Isoperla clio (Newman)

Isoperla richardsoni Frison

$\begin{array}{cc} & X \\ X & X \\ X & X \\ X & \\ X & X \\ & X\end{array}$


Perlidae

Clioperla clio (Newman)

$\mathrm{X}$

Yugus bulbosus (Frison)

Yugus arinus (Frison)

Diura sp. Billberg

Renenus bilobatus

(Needham and Claasen)

Isoperla bilineata (Say)

Isogenoides hansoni (Ricker)

$\mathrm{X}$

$X$
$X$

Acroneuria lycorias (Newman)

Acroneuria internata (Walker)

Acroneuria carolinensis (Banks)

Acroneuria abnormis (Newman)

Acroneuria sp. Pictet

$\begin{array}{cc}X & X \\ X & X \\ X & X \\ & X\end{array}$

Agnetina annulipes (Hagen)

X $\quad X$

$\mathrm{X}$

X

$\mathrm{X}$

$X$

X

Hemiptera

Gerridae

Gerris caniculatus Say

Gerris remigis Say

Gerris conformis (Uhler)

Gerris insperatus Drake and Hottes

$\begin{array}{cc}X & X \\ X & X \\ X & \\ X & X\end{array}$

Veliidae

Rhagovelia obesa Uhler

$\mathrm{X}$

Microvelia borealis Bueno

Microvelia americana (Uhler)

$\mathrm{X}$

$\mathrm{X}$

Coleoptera

Hydrophilidae

Sperchopsis tesselatus (Ziegler)

$\mathrm{X}$

Carabidae

Pterostichus diligendus Chaudoir

$\mathrm{X}$

Megaloptera

Corydalidae

Nigronia serricornis (Say)

Corydalus cornutus (L.)

$\mathrm{X}$

$\mathrm{X}$

Sialidae

Sialis sp. Latreille

$\mathrm{X}$

Trichoptera

Polycentropidae

Polycentropus chelatus Curtis

X 
Polycentropus centralis Banks

Polycentropus remotus Banks

Polycentropus sp. Curtis

$\begin{array}{ll}X & X \\ X & X \\ & X\end{array}$

Rhyacaphilidae

Rhyacophila fuscula (Walker)

Rhyacophila vibrox Milne

$\mathrm{X} \quad \mathrm{X}$

Rhyacoplila fenestra Ross

$\mathrm{X} \quad \mathrm{X}$

Diptera

Empididae

Rhamphoyia sp. Meigen

$\mathrm{X}$

$\mathrm{X}$

Tipulidae

Hexatoma sp. Latreille

Limnophila (Lasiomastix) subtenuicornis (Alexander)

Pseudolimnophila (P.) contempta (Osten Sacken)

Eriocera spinosa (Osten Sacken)

Dolichopeza (oropeza) carolus

Alexander

Dolichopeza (oropeza) walleyi

(Alexander)

Hexatoma (Eriocera) brachycera

Hexatoma (Eriocera) brevicornis Alexander

Hexatoma (Eriocera) spinosa

(Osten Sacken)

Brachypremna dispellans

(Walker)

Pedicia (Trichyphora) vernalis

(Osten Sacken)

Tabanidae

Tabanus sp. Linneaus

Chrysops furcatus Walker

X

X

Chrysops sp. Meigen

$X$

$\mathrm{X}$

Dolochopodidae

Telmaturgus parvus (Van Duzee)

X

$\mathrm{X}$

\section{Collector-Gatherers}

Phylum Arthropoda - Class Isopoda

Isopoda

Asellus militaris Hay

X

X 
Phylum Arthropoda - Class Insecta

Collembola

Entomobryidae

Seira sp. MacGillivray

$\mathrm{X}$

Salina banksi MacGillivray

$\mathrm{X}$

Ephemerellidae

Serratella sp. Edmunds

Eurylophella sp. (McDunnough)

Ephemerella sp. Walsh

$\begin{array}{cc}X & X \\ X & X \\ X & X\end{array}$

Ephemeroptera

Leptophlebiidae

Paraleptophlebia adoptiva

$\mathrm{X}$

X

(McDunnough)

Paraleptophlebia debilis

(Walker)

Paraleptophlebia activa

$\mathrm{X}$

(McDunnough)

Leptophlebia nebulosa

(Walker)

Leptophlebia cupida (Say)

X $\quad \mathrm{X}$

X $\quad X$

X $\quad X$

Baetidae

Baetis flavistriga

X

X

McDunnough

Acentrella turbida

X

(McDunnough)

Ephemeridae

Ephemera guttulata Pictet

Ephemera simulans Walker

X

$\mathrm{X}$

Trichoptera

Hydroptilidae

Agraylea multipunetata Curtis

X

Diptera

Syrphidae

Melangyna sp. Becker

X

X

Phoridae

Ephydridae

Lytogaster sp. Becker

X

X 
Ceratopogonidae

Atrichopogon sp. Kieffer

$\mathrm{X}$

X

Tipulidae

Erioptera (Mesocyphora)

X

caliptera Say

Ulomorpha pilosella

X

(Osten Sacken)

Stratiomyidae

Euparyphus sp. Gerstacker

X

X

Sarcophagidae

Chironomidae

Nilothauma sp. Eaton

Chironomus sp. Meigen

X

$\mathrm{X}$

Telmatoscopus sp. Eaton

Threticus sp. Eaton

$\mathrm{X}$
$\mathrm{X}$

X

Psychodidae

Dixa sp. Meigen

X

X

\section{Collector-filterers}

Phylum Arthropoda - Class Insecta

Ephemeroptera

Isonychiidae

Isonychia sp. Eaton

$\mathrm{X}$

Trichoptera

Philopotamidae

Wormaldia (=Dolophilus) moesta (Banks)

Dolophilus shawnee Ross

Chimarra aterrima Hagen

X

X

X

Hydropsychidae

Diplectrona modesta Banks

Cheumatopsyche pettiti (Banks)

Hydropsyche sp. Pictet

Potamyia flava (Hagen)

Parapsyche apicalis (Banks)

Cheumatopsyche sp. Wallengren

$\mathrm{X}$

X $\quad X$

$\mathrm{X} \quad \mathrm{X}$

$\begin{array}{ll} & X \\ X & X\end{array}$


Diptera

Simuliidae

Culicidae
Simulium tuberosum

(Lundstrom)

Cnephia (Stegopterna)

mutata (Malloch)

Prosimulium rhizophorum

Stone and Jamnback

Prosimulium (prosimulium)

magnum Dyar and Shannon

Anopheles punctipennis (Say)

Aedes apicalis
$\mathrm{X}$

X X

X

X $\quad X$

$\begin{array}{ll}X & X \\ X & X\end{array}$

\section{Shredders}

Phylum Arthropoda - Class Insecta

Plecoptera

Nemouridae

Nemoura trispinosa Claasen

Amphinemura nigritta

(Provancher)

Amphinemura delosa (Ricker)

Ostracerca truncata (Claassen)

X $\quad X$

$X \quad X$

X $\quad X$

$\mathrm{X}$

Peltoperlidae

Peltoperla arcuata Needham

X $\quad X$

Capniidae

Allocapnia recta (Claassen)

Allocapnia maria Hanson

X $\quad X$

Leuctridae

Leuctra sibleyi Claassen

Leuctra ferruginea (Walker)

Leuctra tenuis (Pictet)

Leuctra sp. Stephens

Paraleuctra sara (Claassen)

$\mathrm{X}$

$\begin{array}{ll} & \text { X } \\ \text { X } & \text { X } \\ \text { X } & \text { X } \\ \text { X } & \text { X } \\ \text { X } & \end{array}$

Coleoptera

Chrysomelidae

Monocesta coryli Say

X

X 
Trichoptera

Lepidostomatidae

Limnephilidae

Brachycentridae

Lepidoptera

Pyralidae

Diptera

Tipulidae
Lepidostoma liba Ross

Lepidostoma sp. Rambur

Pycnopsyche luculenta (Betten)

Pycnopsyche gentilis McLachlan

Hydatophylax argus (Harris)

Platycentropus sp. Ulmer

Ironoquia punctatissima (Walker)

Chyranda centralis (Banks)

Micrasema rusticum (Hagen) $\begin{array}{ll}\text { X } & \text { X } \\ & X\end{array}$

X $\quad X$

X $\quad X$

$\begin{array}{ll}X & X \\ X & X\end{array}$

X $\quad X$

$\mathrm{X}$

X

X

X

$\begin{array}{ll}X & X \\ X & X\end{array}$

$X$
$X$
$X$
$X$
$X$
$X$
$X$
$X$

$X$
$X$

Synclita sp. Lederer 


\section{Scrapers}

Ephemeroptera

Heptageniidae

Ameletidae

Coleoptera

Psephenidae

Elmidae

Trichoptera

Goeridae

Hydroptilidae

Heliopsychidae

Glossosomatidae

Molannidae
Epeorus pleurialis (Banks)

Epeorus vitrea (Walker)

Epeorus vitrea (subgenus Iron)

Eaton

Epeorus sp. Eaton

Stenonema meririvulanum

Carle and Lewis

Stenonema femoratum (Say)

Stenonema sp. Traver

Stenacron carolina (Banks)

Stenacron sp. Jensen

Nixe rusticalis (McDunnough)

Cinygmula sp. McDunnough

Ameletus lineatus Traver

Ameletus ludens Needham

$\begin{array}{cc}\text { X } & \text { X } \\ X & \text { X } \\ X & \text { X } \\ & \\ X & X \\ X & X \\ & \\ & \text { X } \\ X & \text { X } \\ & \text { X } \\ \text { X } & \text { X } \\ \text { X } & \text { X } \\ \text { X } & \text { X }\end{array}$

$\mathrm{X}$

X $\quad X$

X $\quad$ X

Stenelmis lateralis Sand
Goera stylata Curtis

Goera sp. Banks

Hydroptila hamata Morton

Hydroptila sp. Dalman

Heliopsyche borealis Hagen

Agapetus illini Ross

Glossosoma nigrior Banks

Molanna blenda Sibley

Molanna uniophila Vohries
$\begin{array}{ll}X & X \\ X & X\end{array}$

X $\quad X$

$\mathrm{X}$

X $\quad X$

X

$\mathrm{X}$ 
KR

MH

Uenoidae

Neophylax consimilis (Betten)

Neophylax autumnus Vorhies

X

X

$\mathrm{X}$

Odontoceridae

Psilotreta indecisa (Walker)

X 


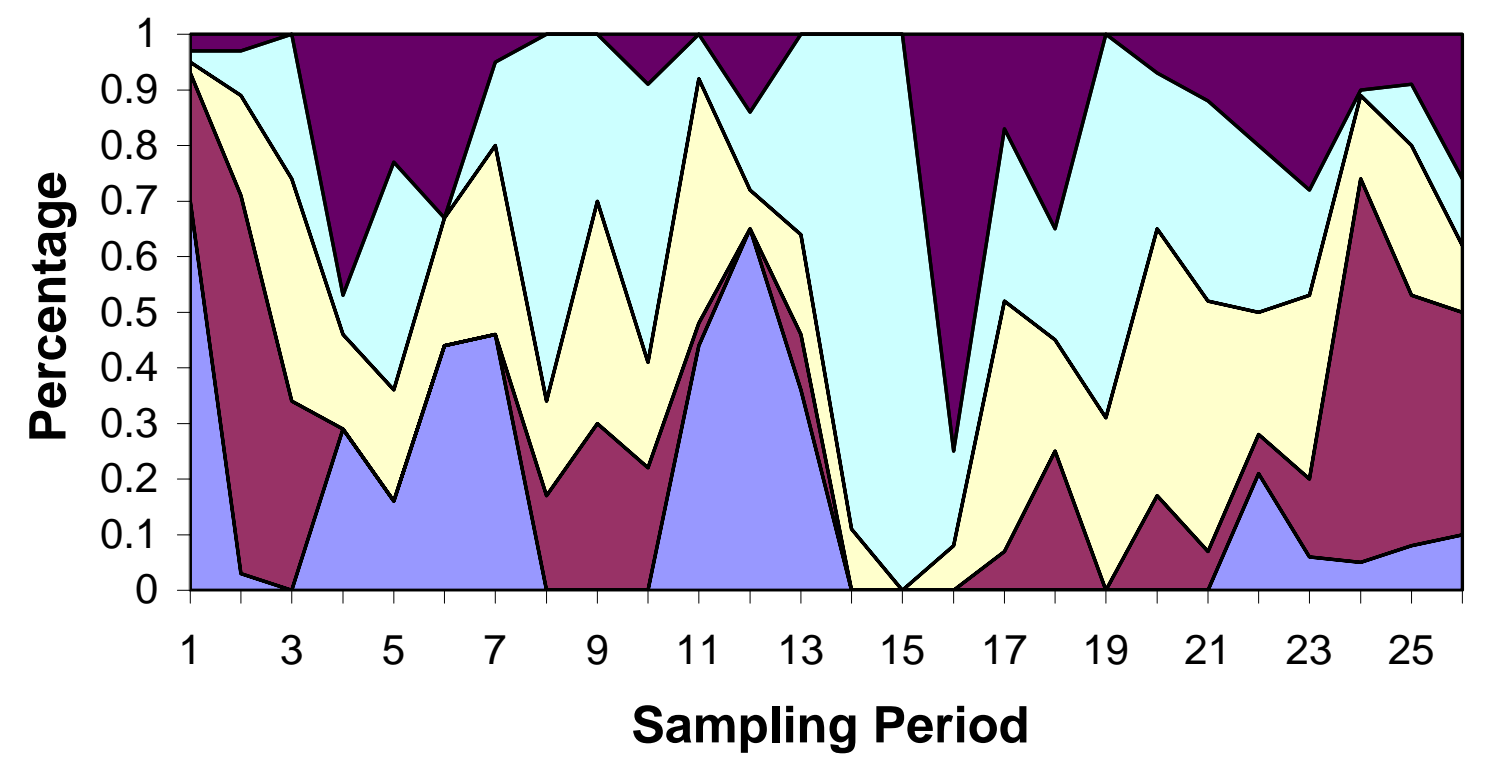

口Scraper

$\square$ Shredder

$\square$ Predator

$\square$ Collector-Gatherer

$\square$ Collector-Filterer

Figure 9a. Functional feeding groups of invertebrates collected at Kent

Run. 


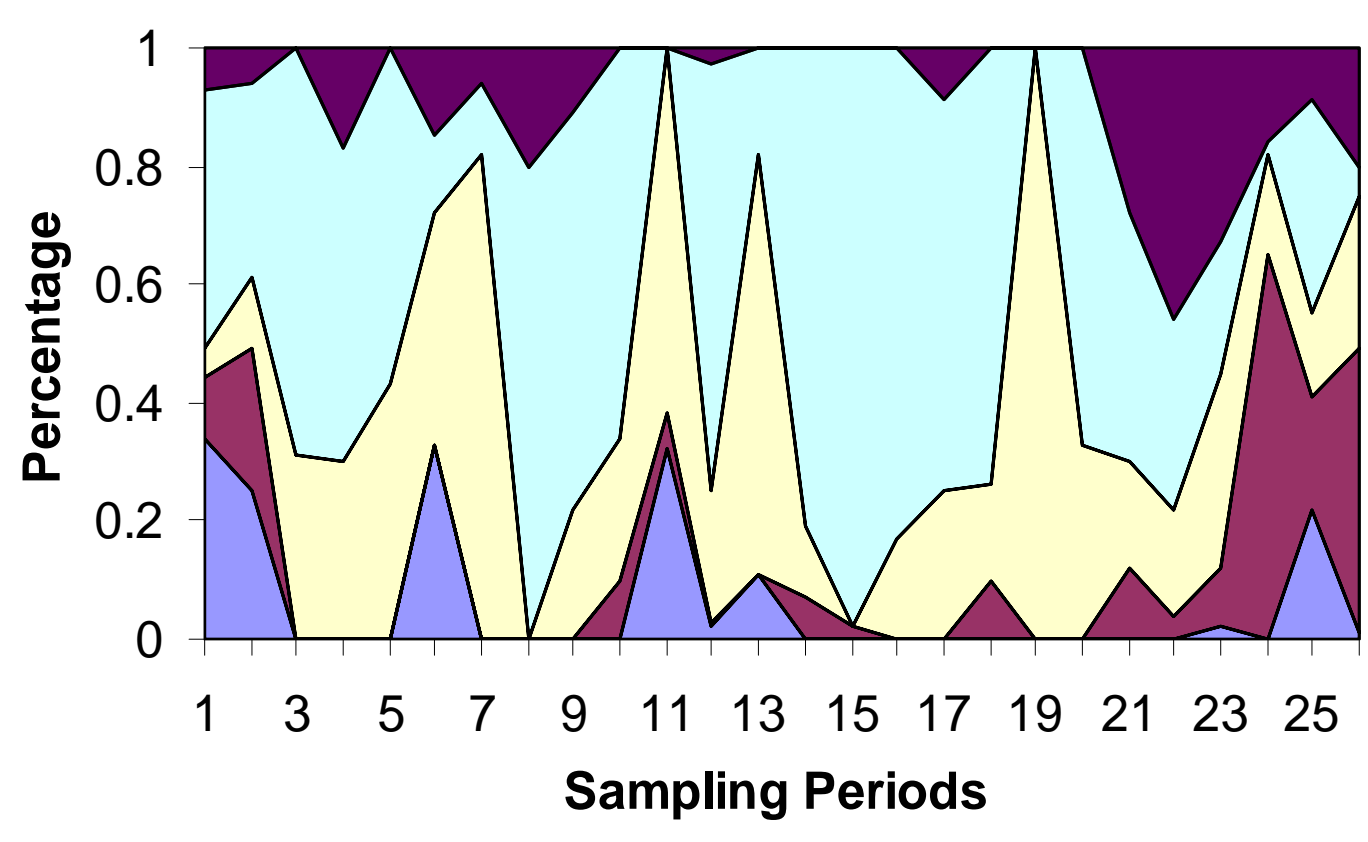

$\square$ Scraper

$\square$ Shredder

$\square$ Predator

$\square$ Collector-Gatherer

$\square$ Collector-Filterer

Figure 9b. Functional feeding groups of invertebrates collected at Munnell Hollow 


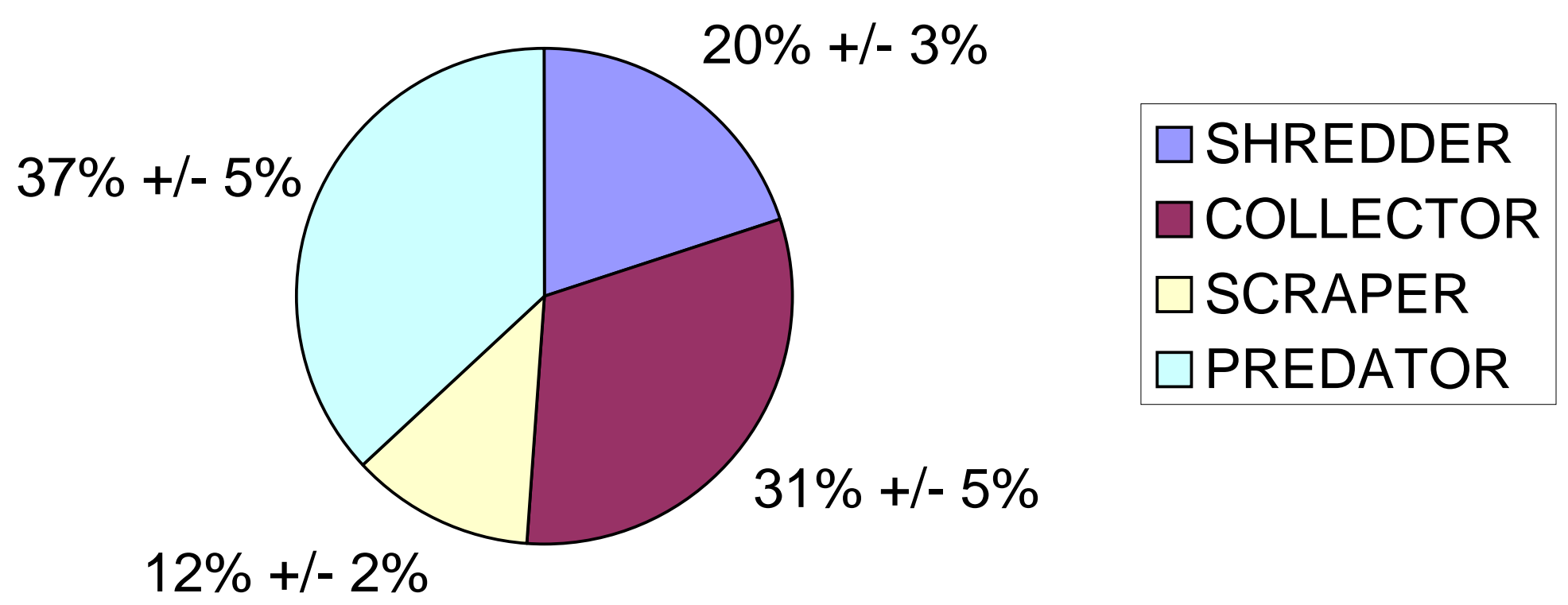

Figure 10. Percentages of functional feeding groups for Kent Run for all samples combined for all sampling periods 


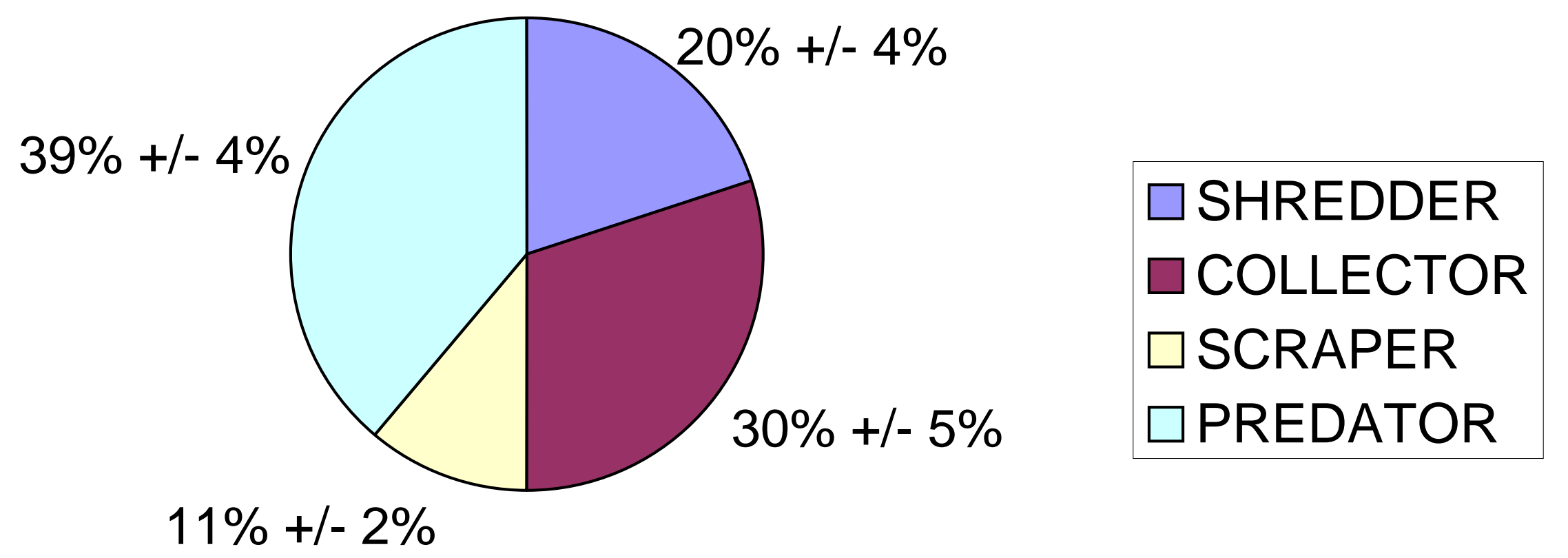

Figure 11. Percentages of functional feeding groups for Munnell Hollow for all samples combined for all sampling periods 


\section{Invertebrates Community Metrics - Immatures}

Over the entire 26 sampling periods of the study, significant differences between the streams occurred in 12 of the 33 metrics (Table 6). Kent Run was significantly higher with regard to number of collector-filterer taxa and percentage of collector-filterers, number of collector-gatherer taxa and percentage of collector-gatherers, and percentage of Odonata. Munnell Hollow was significantly higher with regard to number of Ephemeroptera taxa and percentage of Ephemeroptera, number of EPT taxa, number of shredder taxa and percentage of shredders, percentage of predators, and percentage of Diptera.

Accordingly, for every community metric, there was at least one sampling period in which a significant difference occurred between Kent Run and Munnell Hollow (Table 6). A significant difference in the total number of individuals and total number of individuals per taxa occurred between streams at period 1 and 15 with Kent Run having the greater amount. Further, the number of Coleoptera, the percentage of 1 dominant taxon, and the percentage of 5 dominant taxa were all higher at Munnell Hollow.

There were significant differences between streams with a number of related community metrics (i. e. number and percentage of an order, family, or functional feeding group). At Kent Run, the following correlating metrics were higher: the number of Plecoptera taxa and percentage of Plecoptera were higher at periods 2, 24, and 25; the number of Trichoptera taxa was higher at Kent Run 3 out of 5 periods and the percentage of Trichoptera was higher 4 out of 8 periods. Both metrics were higher at Kent Run at period 11. Both the number of EPT taxa and the percentage of EPT were higher at period 25. Where there was a significant difference between the number of collector-filterer 
taxa and percentage of collector-filterer individuals, the values were all greater at Kent Run. A correlation occurred at periods 4 and 7 , where both the number of collectorfilterer taxa and percentage of collector-filterer individuals were higher. At periods 2, 9, and 25, the number of collector-gatherer taxa and the percentage of collector-gatherer individuals were significantly different, with the higher values at Kent Run. In addition, at all periods in which there was a significant difference for percentage of collectorgatherer individuals, the higher value occurred at Kent Run. Another correlation occurred with number of scraper taxa and percentage of scraper individuals, with higher values occurring at Kent Run for both related metrics. These metrics corresponded at periods 4 and 16.

Similarly, where there were significant differences between the streams with Munnell Hollow having the greater values, there were corresponding metrics that were greater at the same sampling period. The number of Ephemeroptera taxa, percentage of Ephemeroptera, and the number of Heptageniidae taxa were significantly different at period 21. Both the number of EPT taxa and percentage of EPT were also higher at Munnell Hollow at period 21. At periods 1 and 17, the number of shredder taxa and the percentage of shredders was significantly different and was higher at Munnell Hollow. Finally, the number of Diptera taxa and the percentage of Diptera, were both higher at Munnell Hollow at periods 2 and 5.

For a number of the community metrics where there was a significant difference between the two streams, there was an equal number of sample periods higher at Kent Run and Munnell Hollow. These metrics include number of predator taxa, percentage of 
Megaloptera, percentage of Trichoptera, percentage of EPT taxa, and percentage of Coleoptera. 
Table 6. Immatures: Community Metrics. High and low values are given for Kent Run and Munnell Hollow. Sample periods in which high and low values occurred are shown in parentheses. Significant stream differences among periods and for the entire study $(* *)$ are indicated. (Using least squares means).

\begin{tabular}{|c|c|c|c|c|c|c|}
\hline $\begin{array}{r}\text { COMMUNITY } \\
\text { METRIC }\end{array}$ & $\begin{array}{l}\text { LOW } \\
\text { KR }\end{array}$ & $\begin{array}{l}\mathrm{HIGH} \\
\mathrm{KR}\end{array}$ & $\begin{array}{r}\text { LOW } \\
\text { MH }\end{array}$ & $\begin{array}{c}\text { HIGH } \\
\text { MH }\end{array}$ & $\begin{array}{c}\text { PERIOD } \\
\text { SIGNIFICANT } \\
\text { DIFFERENCE }\end{array}$ & $\begin{array}{l}\text { STUDY } \\
\text { SIGNIFICANT } \\
\text { DIFERENCE }\end{array}$ \\
\hline Total No. of Taxa & $1.33(10,14,17)$ & $14.00(26)$ & $0.67(14)$ & $16.00(6)$ & $12,21,23,24,25$ & \\
\hline Total No. of Individuals & $1.33(17)$ & $150.00(1)$ & $1.00(19)$ & $93.67(26)$ & 1,15 & \\
\hline $\begin{array}{l}\text { Total No. of Individuals } \\
\text { Per Taxon }\end{array}$ & $0.47(22)$ & $28.67(15)$ & $0.67(2)$ & $6.23(26)$ & 1,15 & \\
\hline No. Ephemeroptera Taxa & $\begin{array}{l}0.00(3,7,13,14,15,16,17 \\
18,19,20,21)\end{array}$ & $3.67(26)$ & $\begin{array}{c}0.00(3,5,8,9,14,16 \\
17,18,19,20)\end{array}$ & $5.33(26)$ & $6,9,12,21,26$ & $* *$ \\
\hline No. Heptageniidae Taxa & $\begin{array}{l}0.00 \text { (all except } 1,2,4,5,6,8, \\
\quad 12,23,24,25,26)\end{array}$ & $1.67(26)$ & $\begin{array}{c}0.00 \text { (all except } 1,4,6,7 \\
12,21,22,23,24,25,26)\end{array}$ & $2.00(26)$ & $1,7,21$ & \\
\hline No. Plecoptera Taxa & $\begin{array}{l}0.00(4,6,7,9,10,11,12,13 \\
14,16\end{array}$ & $5.33(26)$ & $0.00(2,5,6,7,8,14,16,22)$ & $6.00(26)$ & $2,12,21,24,25$ & \\
\hline No. Trichoptera Taxa & $\begin{array}{l}0.33(1,2,3,14,17,19 \\
21,22)\end{array}$ & $2.67(26)$ & $0.00(11,16,19)$ & $2.67(26)$ & $1,11,22,24,25$ & \\
\hline No. EPT Taxa ${ }^{1}$ & $0.33(14)$ & $11.67(26)$ & $0.00(16)$ & $14.00(16)$ & $21,24,25,26$ & $* *$ \\
\hline No. Diptera Taxa & $0.00(6,8,9,10,11,13,14,15)$ & $1.67(1,19,24,26)$ & $0.00(8,10,11,13,14,19)$ & $2.67(25)$ & $1,12,17,19,23,25$ & \\
\hline No. Coleoptera Taxa & $0.00($ all except 5,9$)$ & $1.00(5)$ & $\begin{array}{l}0.00(\text { all except } 9,10 \\
18,22)\end{array}$ & $0.67(9,10)$ & $5,9,10,18,22$ & \\
\hline $\begin{array}{l}\text { No. Collector-Filterer } \\
\text { Taxa }\end{array}$ & $\begin{array}{l}0.00(3,8,9,10,14,15,16,17 \\
18,19,20,21,22)\end{array}$ & $1.33(25)$ & $\begin{array}{r}0.00(\text { all except } 1,2,6 \\
11,12,13,23,25,26)\end{array}$ & $1.67(25)$ & $4,5,7,13,24$ & $* *$ \\
\hline $\begin{array}{l}\text { No. Collector-Gatherer Taxa } \\
\text { Taxa }\end{array}$ & $\begin{array}{l}0.00(4,5,6,7,12,14,16,17 \\
19,21,22)\end{array}$ & $3.67(26)$ & $\begin{array}{c}0.00(3,4,5,6,7,8,9,13, \\
14,16,17,19,20)\end{array}$ & $3.67(26)$ & $1,2,9,21,24,25$ & ** \\
\hline No. Predator Taxa & $0.00(15)$ & $4.33(25)$ & $0.00(2,8,14,15)$ & $5.66(26)$ & $12,24,25,26$ & \\
\hline No. Shredder Taxa & $0.00(6)$ & $2.33(15,26)$ & $0.00(11,19)$ & $3.00(1)$ & $1,17,19,21$ & ** \\
\hline No. Scraper Taxa & $\begin{array}{l}0.00(3,8,9,10,11,13,14,15 \\
19)\end{array}$ & $2.33(26)$ & $\begin{array}{c}0.00(2,3,5,10,11,13 \\
14,15,16,18,19,20)\end{array}$ & $2.33(26)$ & $4,5,16,21,23$ & \\
\hline Percentage of Megaloptera & $\begin{array}{l}0.00(1,5,6,8,9,10,15 \\
16,17,19,20,21,22 \\
23)\end{array}$ & $0.43(11)$ & $\begin{array}{l}0.00(2,4,8,9,10,14,15 \\
16,19,20,21,22,24, \\
25)\end{array}$ & $0.18(11)$ & $6,7,11,17$ & \\
\hline Percentage of Ephemeroptera & $\begin{array}{l}0.00(3,7,13,14,15,16 \\
17,18,19,20,21)\end{array}$ & $0.37(26)$ & $\begin{array}{l}0.00(3,5,8,9,14,16 \\
17,18,19,20)\end{array}$ & $0.81(24)$ & $1,9,11,21,24$ & ** \\
\hline Percentage of Plecoptera & $\begin{array}{l}0.00(4,6,7,9,10,11,12, \\
13,14,16)\end{array}$ & $0.79(2)$ & $\begin{array}{l}0.00(2,5,6,7,8,14 \\
16,22)\end{array}$ & $1.00(19)$ & $2,3,11,13,15,19,24,25$ & \\
\hline Percentage of Trichoptera & $0.00(1)$ & $0.75(16)$ & $0.00(11,16,19)$ & $1.00(8)$ & $1,3,7,11,12,15,16,22$ & \\
\hline Percentage of EPT Taxa & $0.28(1,18,22)$ & $0.94(23,26)$ & $0.00(16)$ & $1.00(8,19)$ & $1,2,12,13,16,19,21,25$ & \\
\hline Percentage of Chironomidae & 0.00 (all except 24,26 ) & $0.22(24)$ & 0.00 (all periods) & 0.00 (all periods) & 24 & \\
\hline $\begin{array}{l}\text { Percentage of } 1 \text { Dominant } \\
\text { Taxon }\end{array}$ & $9.52(22)$ & $88.89(14)$ & $24.51(21)$ & $100.00(19)$ & 19 & \\
\hline
\end{tabular}




\begin{tabular}{|c|c|c|c|c|c|c|}
\hline $\begin{array}{l}\text { COMMUNITY } \\
\text { METRIC }\end{array}$ & $\begin{array}{l}\text { LOW } \\
\text { KR }\end{array}$ & $\begin{array}{l}\mathrm{HIGH} \\
\mathrm{KR}\end{array}$ & $\begin{array}{l}\text { LOW } \\
\text { MH }\end{array}$ & $\begin{array}{l}\mathrm{HIGH} \\
\mathrm{MH}\end{array}$ & $\begin{array}{l}\text { PERIOD } \\
\text { SIGNIFICANT } \\
\text { DIFFERENCE }\end{array}$ & $\begin{array}{c}\text { STUDY } \\
\text { SIGNIFICANT } \\
\text { DIFFERENCE }\end{array}$ \\
\hline $\begin{array}{c}\text { Percentage of } 5 \text { Dominant } \\
\text { Taxa }\end{array}$ & $23.81(22)$ & $100.00(6,14,17)$ & $59.75(26)$ & $\begin{array}{c}100.00(8,15 \\
16,19)\end{array}$ & 22 & \\
\hline Percentage of Heptageniidae & $\begin{array}{l}0.00 \text { (all except } 1,2,4,5,6,8 \\
12,23,24,25,26)\end{array}$ & $0.33(6)$ & $\begin{array}{l}0.00 \text { (all except } 1,4 \text {, } \\
6,7,12,21,22,23 \\
24,25,26)\end{array}$ & $0.65(24)$ & 24,25 & \\
\hline Percentage of Odonata & 0.00 (all except $4,5,6,7,8,9,10)$ & $0.33(9)$ & 0.00 (all except 10$)$ & $0.02(10)$ & 6,9 & ** \\
\hline Percentage of Coleoptera & 0.00 (all except 5,9$)$ & $0.17(5)$ & $\begin{array}{l}0.00 \text { (all except } 9,10, \\
18,22)\end{array}$ & $0.34(9)$ & 5,9 & \\
\hline Percentage of Diptera & $0.00(6,8,9,10,11,13,14,15,19)$ & $0.72(1)$ & $0.00(8,10,11,13,14)$, & $0.83(16)$ & $1,15,16,18,19,20,25$ & ** \\
\hline $\begin{array}{l}\text { Percentage of Collector- } \\
\text { Filterers }\end{array}$ & $\begin{array}{l}0.00(3,8,9,10,14,15,16,17 \\
18,19,20,21,22)\end{array}$ & $0.71(1)$ & $\begin{array}{c}0.00(3,4,5,7,8,9,10,14 \\
15,16,17,18,19,20 \\
21,22,24)\end{array}$ & $0.33(1,6,11)$ & $1,4,7,12,13$ & $* *$ \\
\hline $\begin{array}{c}\text { Percentage of Collector- } \\
\text { Gatherers }\end{array}$ & $\begin{array}{l}0.00(4,5,6,7,12,14,16 \\
17,19,21,22)\end{array}$ & $0.69(2,24)$ & $\begin{array}{c}0.00(3,4,5,6,7,8,9,13 \\
14,16,17,19,20)\end{array}$ & $0.65(24)$ & $2,3,9,18,25$ & $* *$ \\
\hline Percentage of Predators & $0.00(15)$ & $0.49(20)$ & $0.00(2,8,14,15)$ & $1.00(19)$ & $7,13,19$ & $* *$ \\
\hline Percentage of Shredders & $0.00(6)$ & $1.00(15)$ & $0.00(11,19)$ & 0915) & $1,3,4,12,16,17,18,19,20$ & ** \\
\hline Percentage of Scrapers & $\begin{array}{l}0.00(3,8,9,10,11,13,14 \\
15,19)\end{array}$ & $0.75(16)$ & $\begin{array}{r}0.00(2,3,5,10,11,13 \\
14,15,16,18,19,20)\end{array}$ & $0.46(22)$ & $4,16,18,22$ & \\
\hline
\end{tabular}

${ }^{1}$ EPT $=$ Ephemeroptera + Plecoptera + Trichoptera 


\section{Invertebrate Community Metrics - Adults}

Comparison by ANOVA of various community metrics for adults is shown in Table 7. A total of 35 metrics are listed with the sample periods indicated where significant differences occurred between streams. All values used in Table 7 were determined by least square means.

For the 26 sampling periods of the study, significant differences between the streams occurred in 12 of the 35 adult metrics (Table 7). These are the same 12 metrics that were significantly different between the streams for the immatures. Kent Run was significantly higher with regard to number of collector-filterer taxa and percentage of collector-filterers, number of collector gatherer taxa and percentage of collector gatherers, and for percentage of Odonata. Higher values were found at Munnell Hollow for both number of Ephemeroptera taxa and percentage of Ephemeroptera, number of EPT taxa, number of shredder taxa and percentage of shredders, percentage of predators, and percentage of Diptera.

A significant difference in the total number of individuals and total number of individuals per taxa occurred between streams at periods 1 and 15 with Kent Run having the greater amount. This corresponds with the immature results. Likewise, as with the immatures, the number of Coleoptera, the percentage of 1 dominant taxon, and the percentage of 5 dominant taxa were all higher at Munnell Hollow.

As with the immature invertebrates, there were significant differences between streams with a number of related community metrics. At Kent Run, the following correlating metrics were higher. Both the number of Plecoptera taxa and the percentage 
of Plecoptera were higher at periods 2, 24, and 25. These same three periods were correlated with the immature data for the same two metrics. Both the number of Trichoptera taxa and the percentage of Trichoptera at Kent Run were higher at period 11. The immature data previously showed a higher number of Trichoptera taxa at period 11 for Kent Run. The percentage of EPT taxa was higher at period 25 as it was with the immatures. A correlation between the number of collector-filterer taxa and the percentage of collector-filterers occurred at periods 4, 7, and 13 showing higher number of both metrics. The immature data also showed higher numbers at periods 4 and 7 . At sampling periods 9 and 25, both the number of collector-gatherers and the percentage of collector-gatherers were higher at Kent Run. The immatures correspond with higher numbers at sampling periods 9 and 25. An additional correlation occurred with the number of scraper taxa and the percentage of scrapers. As with the previous metrics, where a significant difference occurred between streams, the values were higher at Kent Run. Both of these metrics correlate at period 4 for the adults as well as the immatures. Similarly, where there were significant differences between streams with Munnell Hollow having the greater values, there were corresponding metrics that were greater at the same sampling period. The number of Ephemeroptera taxa and the percentage of Ephemeroptera were higher at sampling period 21, as occurred with the immatures. Both the number of EPT taxa and the percentage of EPT were also higher at Munnell Hollow at period 21, corresponding to the immature metrics. At periods 1 and 17, the number of shredder taxa and the percentage of shredders was significantly higher at Munnell Hollow. These same metrics also correlated for the immatures. The number of Diptera taxa and the percentage of Diptera were higher at period 25. For the following 
community metrics where there was a significant difference between the two streams, there were an equal number of sample periods higher at Kent Run and Munnell Hollow. These metrics include percentage of Megaloptera, percentage of Trichoptera, percentage of Coleoptera, and the Simpson Diversity Index. The percentage of 1 dominant taxon was significantly different between streams with the higher value at Munnell Hollow at period 19, and the percentage of 5 dominant taxa higher at period 22. 


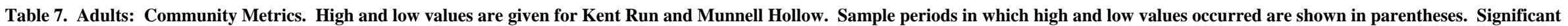
stream differences among periods and for the entire study $(* *)$ are indicated. (Using least squares means).

\begin{tabular}{|c|c|c|c|c|c|c|}
\hline COMMUNITY METRIC & $\begin{array}{c}\text { LOW } \\
\text { KR }\end{array}$ & $\begin{array}{l}\mathrm{HIGH} \\
\mathrm{KR}\end{array}$ & $\begin{array}{c}\text { LOW } \\
\text { MH }\end{array}$ & $\begin{array}{l}\mathrm{HIGH} \\
\mathrm{MH}\end{array}$ & $\begin{array}{l}\text { PERIOD } \\
\text { SIGNIFICANT } \\
\text { DIFFERENCE }\end{array}$ & $\begin{array}{l}\text { STUDY } \\
\text { SIGNIFICANT } \\
\text { DIFERENCE }\end{array}$ \\
\hline Total No. of Individuals & $1.33(17)$ & $150.00(1)$ & $1.00(19)$ & $93.67(26)$ & 1,15 & \\
\hline $\begin{array}{l}\text { Total No. of Individuals } \\
\text { Per Taxon }\end{array}$ & $0.47(22)$ & $28.67(15)$ & $0.67(2)$ & $6.23(26)$ & 1,15 & \\
\hline No. Ephemeroptera Taxa & $\begin{array}{l}0.00(3,7,13,14,15,16,17 \\
18,19,20,21)\end{array}$ & $3.67(26)$ & $\begin{array}{l}0.00(3,5,8,9,14,16 \\
17,18,19,20)\end{array}$ & $5.33(26)$ & $6,9,12,21,26$ & $* *$ \\
\hline No. Heptageniidae Taxa & $\begin{array}{l}0.00 \text { (all except } 1,2,4,5,6,8 \\
12,23,24,25,26)\end{array}$ & $1.67(26)$ & $\begin{array}{r}0.00 \text { (all except } 1,4,6,7 \\
12,21,22,23,24,25,26)\end{array}$ & $2.00(26)$ & $1,7,21$ & \\
\hline No. Plecoptera Taxa & $\begin{array}{l}0.00(4,6,7,9,10,11,12,13 \\
14,16)\end{array}$ & $5.33(26)$ & $0.00(2,5,6,7,8,14,16,22)$ & $6.00(26)$ & $2,12,21,24,25$ & \\
\hline No. Trichoptera Taxa & $0.33(1,2,3,14,17,19,21,22)$ & $2.67(26)$ & $0.00(11,16,19)$ & $2.67(26)$ & $1,11,22,24,25$ & \\
\hline No. EPT Taxa ${ }^{1}$ & $0.33(14)$ & $11.67(26)$ & $0.00(16)$ & $14.00(26)$ & $21,24,25,26$ & ** \\
\hline No. Total Adults & $0.00(19,20)$ & $256.33(26)$ & $0.00(13,19,20)$ & $110.33(5)$ & 26 & \\
\hline No. Diptera Taxa & $0.00(6,8,9,10,11,13,14,15)$ & $1.67(1,19,24,26)$ & $0.00(8,10,11,13,14,19)$ & $2.67(25)$ & $1,12,17,19,23,25$ & \\
\hline No. Coleoptera Taxa & $0.00($ all except 5,9$)$ & $1.00(5)$ & $\begin{array}{l}0.00 \text { (all except } 9,10,18 \\
22 \text { ) }\end{array}$ & $0.67(9,10)$ & $5,9,10,18,22$ & \\
\hline $\begin{array}{l}\text { No. Collector-Filterer } \\
\text { Taxa }\end{array}$ & $\begin{array}{l}0.00(3,8,9,10,14,15,16,17 \\
18,19,20,21,22)\end{array}$ & $1.33(25)$ & $\begin{array}{l}0.00(3,4,5,7,8,9,10,14 \\
15,16,17,18,19,20,21 \\
22,24)\end{array}$ & $1.67(25)$ & $4,5,7,13,24$ & $* *$ \\
\hline $\begin{array}{l}\text { No. Collector-Gatherer } \\
\text { Taxa }\end{array}$ & $\begin{array}{l}0.00(4,5,6,7,12,14,16,17 \\
19,21,22)\end{array}$ & $3.67(26)$ & $\begin{array}{c}0.00(3,4,5,6,7,8,9,13 \\
14,16,17,19,20)\end{array}$ & $3.67(26)$ & $1,9,21,24,25$ & $* *$ \\
\hline No. Predator Taxa & $0.00(15)$ & $4.33(25)$ & $0.00(2,8,14,15)$ & $5.67(26)$ & $12,24,25,26$ & \\
\hline No. Shredder Taxa & $0.00(6)$ & $2.33(15,26)$ & $0.00(11,19)$ & $3.00(1)$ & $1,17,19,21$ & $* *$ \\
\hline No. Scraper Taxa & $\begin{array}{l}0.00(3,8,9,10,11,13,14,15 \\
19)\end{array}$ & $2.33(26)$ & $\begin{array}{c}0.00(2,3,5,10,11,13,14 \\
15,16,18,19,20)\end{array}$ & $2.33(26)$ & $4,5,16,21,23$ & \\
\hline Percentage of Megaloptera & $\begin{array}{c}0.00(\text { all except } 2,3,4,7,11 \\
12,13,14,18,24,25,26)\end{array}$ & $0.43(11)$ & $\begin{array}{c}0.00 \text { (all except } 1 \\
3,5,6,7,11,12, \\
13,17,18,23,26)\end{array}$ & $0.18(11)$ & $6,7,11,17$ & \\
\hline Percentage of Ephemeroptera & $\begin{array}{l}0.00(3,7,13,14,15,16,17 \\
18,19,20,21)\end{array}$ & $0.37(26)$ & $\begin{array}{c}0.00(3,5,8,9,14,16 \\
17,18,19,20)\end{array}$ & $0.81(24)$ & $1,9,11,21,24$ & $* *$ \\
\hline Percentage of Plecoptera & $\begin{array}{l}0.00(4,6,7,9,10,11,12, \\
13,14,16)\end{array}$ & $0.79(2)$ & $\begin{array}{l}0.00(2,5,6,7,8,14 \\
16,22)\end{array}$ & $1.00(19)$ & $2,3,11,13,15,19,24,25$ & \\
\hline Percentage of Trichoptera & $0.00(1)$ & $0.75(16)$ & $0.00(11,16,19)$ & $1.00(8)$ & $1,3,7,11,12,15,16,22$ & \\
\hline Percentage of EPT Taxa & $0.28(1,18,22)$ & $0.94(23,26)$ & $0.00(16)$ & $1.00(8,19)$ & $1,2,12,13,16,19,21,25$ & \\
\hline Percentage of Chironomidae & 0.00 (all except 24,26 ) & $0.21(24)$ & $0.00($ all $)$ & 0.00 (all) & 24 & \\
\hline $\begin{array}{l}\text { Percentage of } 1 \text { Dominant } \\
\text { Taxon }\end{array}$ & $9.52(22)$ & $88.89(14)$ & $24.51(21)$ & $100.00(19)$ & 19 & \\
\hline
\end{tabular}




\begin{tabular}{|c|c|c|c|c|c|c|}
\hline $\begin{array}{l}\text { COMMUNTIY } \\
\text { METRIC }\end{array}$ & $\begin{array}{l}\text { LOW } \\
\text { KR }\end{array}$ & $\begin{array}{l}\text { HIGH } \\
\text { KR }\end{array}$ & $\begin{array}{l}\text { LOW } \\
\text { MH }\end{array}$ & $\begin{array}{l}\mathrm{HIGH} \\
\mathrm{MH}\end{array}$ & $\begin{array}{l}\text { PERIOD } \\
\text { SIGNIFICANT } \\
\text { DIFFERENCE }\end{array}$ & $\begin{array}{c}\text { STUDY } \\
\text { SIGNIFICANT } \\
\text { DIFFERENCE }\end{array}$ \\
\hline $\begin{array}{l}\text { Percentage of } 5 \text { Dominant } \\
\text { Taxa }\end{array}$ & $23.81(22)$ & $100.00(6,14,17)$ & $59.75(26)$ & $\begin{array}{c}100.00(8,15 \\
16,19)\end{array}$ & 22 & \\
\hline Percentage of Heptageniidae & $\begin{array}{l}0.00 \text { (all except } 1,2,4,5,6,8 \\
12,23,24,25,26)\end{array}$ & $0.33(6)$ & $\begin{array}{l}0.00(\text { all except } 1,4 \\
6,7,12,21,22,23 \\
24,25,26)\end{array}$ & $0.65(24)$ & 24,25 & \\
\hline Percentage of Odonata & 0.00 (all except $4,5,6,7,8,9,10)$ & $0.33(9)$ & $0.00($ all except 10$)$ & $0.02(10)$ & 6,9 & ** \\
\hline Percentage of Coleoptera & 0.00 (all except 5,9$)$ & $0.17(5)$ & $\begin{array}{l}0.00 \text { (all except } 9,10, \\
18,22 \text { ) }\end{array}$ & $0.34(9)$ & 5,9 & \\
\hline Percentage of Diptera & $0.00(6,8,9,10,11,13,14,15)$ & $0.72(1)$ & $0.00(8,10,11,13,14,19)$ & $0.83(16)$ & $1,15,16,18,19,20,25$ & $* *$ \\
\hline $\begin{array}{l}\text { Percentage of Collector- } \\
\text { Filterers }\end{array}$ & $\begin{array}{l}0.00(3,8,9,10,14,15,16,17 \\
18,19,20,21,22)\end{array}$ & $0.71(1)$ & $\begin{array}{c}0.00(3,4,5,7,8,9,10,14 \\
15,16,17,18,19,20 \\
21,22,24)\end{array}$ & $0.33(1,6,11)$ & $1,4,7,12,13$ & $* *$ \\
\hline $\begin{array}{l}\text { Percentage of Collector- } \\
\text { Gatherers }\end{array}$ & $\begin{array}{l}0.00(4,5,6,7,12,14,15,16 \\
17,19,21,22)\end{array}$ & $0.69(2,24)$ & $\begin{array}{c}0.00(3,4,5,6,7,8,9,13 \\
14,16,17,19,20)\end{array}$ & $0.65(24)$ & $2,3,9,18,25$ & $* *$ \\
\hline Percentage of Predators & $0.00(15)$ & $0.49(20)$ & $0.00(2,8,14,15)$ & $1.00(19)$ & $7,13,19$ & $* *$ \\
\hline Percentage of Shredders & $0.00(6)$ & $1.00(15)$ & $0.00(11,19)$ & $0.98(15)$ & $1,3,4,12,16,17,18,19,20$ & $* *$ \\
\hline Percentage of Scrapers & $\begin{array}{l}0.00(3,8,9,10,11,13,14, \\
15,19)\end{array}$ & $0.75(16)$ & $\begin{array}{c}0.00(2,3,5,10,11,13 \\
14,15,16,18,19,20)\end{array}$ & $0.46(22)$ & $4,16,18,22$ & \\
\hline Simpson Diversity Index & $0.04(1,14)$ & $0.49(2,12)$ & $0.00(14,19)$ & $0.47(10,24)$ & 2,10 & \\
\hline Shannon Diversity Index & $0.12(14,17)$ & $1.97(26)$ & $0.00(14,19)$ & $2.17(26)$ & $1,17,19,21,23,24$ & \\
\hline
\end{tabular}

${ }^{1} \mathrm{EPT}=$ Ephemeroptera + Plecoptera + Trichoptera 


\section{Seasonal Aspects of Community Metrics for Immatures}

A summary of significant differences in means of the dependent variables as determined by a repeated measures ANOVA, for streams considered simultaneously, is given in Table 8. Table 9 lists significant differences for streams considered separately. The results from the ANOVA for week versus time for both streams combined are shown in Figures 12 through 24. By looking at periods when metrics are higher and lower than other times of the year, it is possible to determine optimal times to monitor the metrics.

Results for combining streams or considering them separately were similar; the figures will show data separately for the two streams. There is a narrow window in which the highest counts were made for the total number of taxa (periods 26, 25, and 1) (Figure 12) and the total number of individuals (periods 1, 26, and 15) (Figure 13). Metrics are much lower for total number of taxa at periods 14 and 16 and from periods 2 through 11 and from periods 16 through 23 for total number of individuals.

For the percentage of collector-filterers, periods with highest counts were period 1 for Kent Run and periods 1, 6, and 11 for Munnell Hollow (Figure 15). For number of collector-filterers, highest values were at period 25 (Figure 20). Periods 14 through 22 gave the lowest mean for both metrics.

Periods 2 and 24 were significantly higher than all other periods for Kent Run for percentage of collector-gatherers (Figure 16). For number of collector-gatherers (Figure 21), period 26 was significantly higher for both streams. The lowest means for percentage of collector-gatherers occurred during periods 4 through 23 , and for the number of collector-gatherers during periods 3 through 22 . 
For Munnell Hollow, highest means for percentage and number of predators (Figures 17 and 22) were at periods 19 and 26, respectively. Highest mean number of predators occurred at Kent Run at period 26. The percentage of shredders (Figure 18) was highest for both streams at period 15 while the number of shredders (Figure 23) was significantly higher at periods 1 and 26 for Munnell Hollow. Optimal counts of shredders occurred at period 26. The lowest means for percentage of shredders were during periods 1 through 7 and 16 through 26. Periods 2 through 14 and 16 through 25 had the lowest means for the number of shredders. The number of scrapers (Figure 24) was significantly higher at period 26 for both Kent Run and Munnell Hollow while the lowest means for this metric occurred during periods 5 through 22. The percentage of scrapers (Figure 19) at period 16 was significantly higher for Kent Run. Periods 1 through 15 and 17 through 26 give the lowest mean values for this metric. No optimal sampling periods are evident for percentage of EPT taxa (Figure 14), but optimal sampling periods for number of EPT taxa are periods 1 and 26 (Figure 25).

\section{Stream Condition Indices for Kent Run and Munnell Hollow}

Stream condition indices using the West Virginia Stream Condition Index were determined for both Kent Run and Munnell Hollow. The highest indices for both streams were at periods 1 and 26 (Table 10). 
Table 8. Repeated measures ANOVA of week vs. time for immatures in combined streams (Kent Run and Munnell Hollow), giving F values and periods where significant differences occurred

\begin{tabular}{|c|c|c|c|}
\hline Dependent Variable & $\frac{\text { Periods with significantly }}{\underline{\text { higher means }}}$ & $\underline{\text { F value }}$ & $\underline{\operatorname{Pr}>F}$ \\
\hline Total Number of Taxa & $26,25,1$ & 16.01 & $<.0001$ \\
\hline Total Number of Individuals & $1,26,15$ & 3.24 & $<.0001$ \\
\hline Percentage, EPT Taxa & $8,26,23$ & 2.92 & $<.0001$ \\
\hline Percentage, Collector-Filterers & $1,6,11$ & 7.57 & $<.0001$ \\
\hline Percentage, Collector-Gatherers & $24,26,2$ & 10.65 & $<.0001$ \\
\hline Percentage, Predators & $19,7,11$ & 3.89 & $<.0001$ \\
\hline Percentage, Shredders & $15,14,8$ & 5.94 & $<.0001$ \\
\hline Percentage, Scrapers & $16,4,23$ & 3.10 & $<.0001$ \\
\hline Number of Collector-Filterers & $25,1,26$ & 6.88 & $<.0001$ \\
\hline Number of Collector-Gatherers & $26,24,1$ & 19.63 & $<.0001$ \\
\hline Number of Predators & $26,25,7$ & 6.47 & $<.0001$ \\
\hline Number of Shredders & $26,1,15$ & 3.17 & $<.0001$ \\
\hline Number of Scrapers & $26,23,25$ & 7.46 & $<.0001$ \\
\hline
\end{tabular}


Table 9. Repeated measures ANOVA of week vs. time for immatures with streams considered separately (Kent Run and Munnell Hollow), giving F values and periods where significant differences occurred

\begin{tabular}{|c|c|c|c|}
\hline$\underline{\text { Dependent variable }}$ & $\frac{\text { Periods with significantly }}{\underline{\text { Higher means }}}$ & $\underline{\text { F Value }}$ & $\underline{\operatorname{Pr}>}$ \\
\hline Total Number of Taxa & $26(\mathrm{M}), 25(\mathrm{~K}), 1(\mathrm{M})$ & 16.01 & $<.0001$ \\
\hline Total Number of Individuals & $1(\mathrm{~K}), 26(\mathrm{M}), 15(\mathrm{~K})$ & 3.24 & $<.0001$ \\
\hline Percentage, EPT Taxa & $8(\mathrm{M}), 26(\mathrm{M})$ & 2.92 & $<.0001$ \\
\hline Percentage, Collector-Filterers & $1(\mathrm{~K}), 6(\mathrm{~K}), 11(\mathrm{~K})$ & 7.57 & $<.0001$ \\
\hline Percentage, Collector-Gatherers & $24(\mathrm{~K}), 26(\mathrm{M})$ & 10.65 & $<.0001$ \\
\hline Percentage, Predators & 19(M), 7(M), 11(M) & 3.89 & $<.0001$ \\
\hline Percentage, Shredders & $15(\mathrm{~K}), 14(\mathrm{~K}), 8(\mathrm{M})$ & 5.94 & $<.0001$ \\
\hline Percentage, Scrapers & $16(\mathrm{~K}), 4(\mathrm{~K}), 23(\mathrm{M})$ & 3.10 & $<.0001$ \\
\hline Number, Collector-Filterers & $25(\mathrm{M}), 26(\mathrm{~K})$ & 6.88 & $<.0001$ \\
\hline Number, Collector-Gatherers & $26(\mathrm{~K}), 24(\mathrm{M}), 1(\mathrm{~K})$ & 19.63 & $<.0001$ \\
\hline Number, Predators & 26(M), 25(K), 7(M) & 6.47 & $<.0001$ \\
\hline Number, Shredders & 26(M), 1(M), 15(K) & 3.17 & $<.0001$ \\
\hline Number, Scrapers & $23(\mathrm{M}), 25(\mathrm{~K})$ & 7.46 & $<.0001$ \\
\hline
\end{tabular}

(M) = Munnell Hollow

(K) = Kent Run 
Table 10. West Virginia Stream Condition Index for Kent Run and Munnell Hollow by sampling periods (Index values 0 through 100; 68.0 and above - not impaired; 60.5 and below - impaired).

Sampling period

Kent Run

Munnell Hollow

1

95

86

2

89

79

3

88

78

4

86

77

5

85

85

76

6

84

76

7

81

75

8

73

9

80

71

10

79

68

11

76

74

68

12

13

75

69

14

75

73

15

74

73

16

75

72

75

73

17

18

74

73

19

74

72

20

78

72

79

75

21

22

81

77

23

85

79

24

25

26

89

93

95

81

82

84

86 


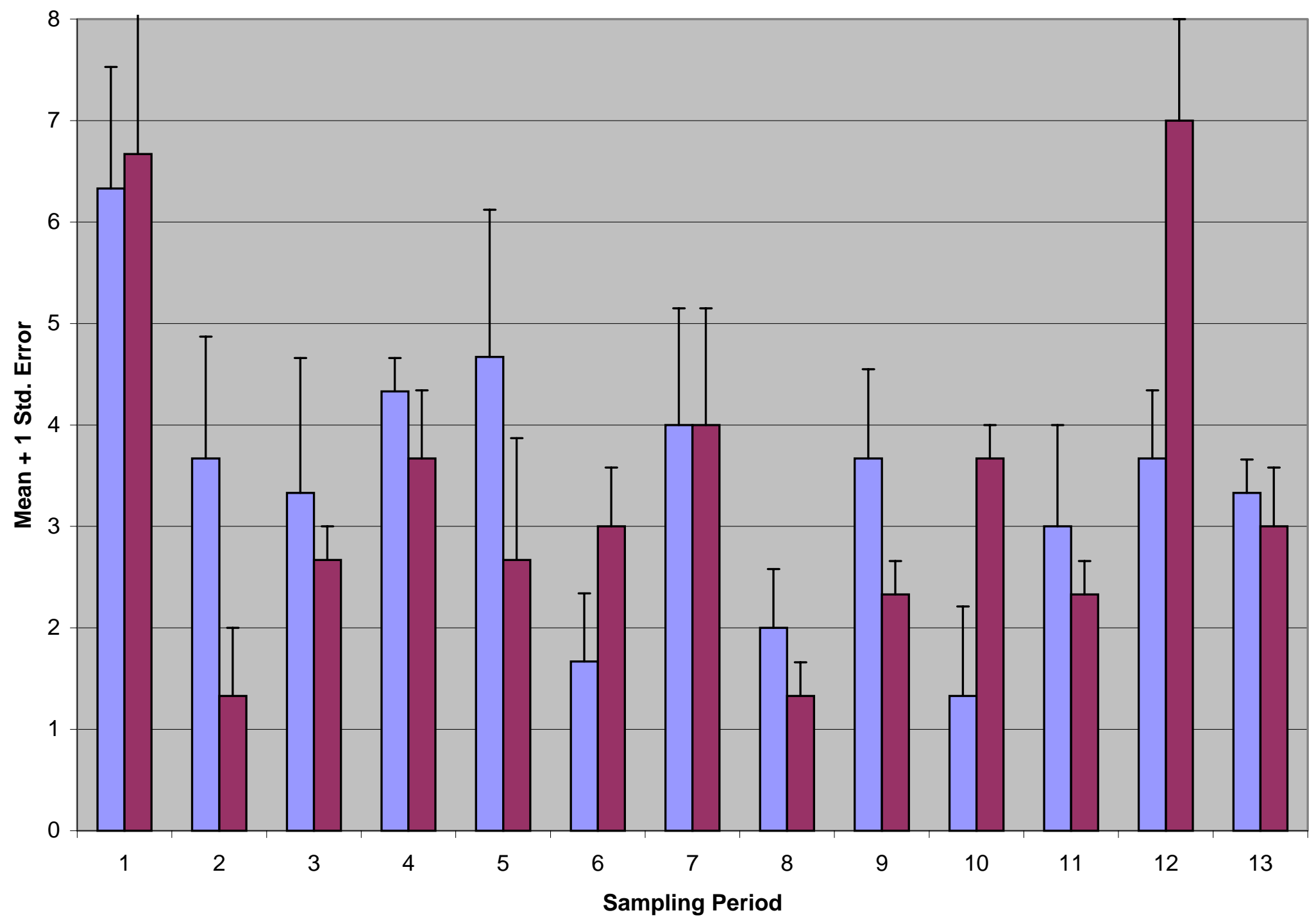

$\square$ Kent Run

$\square$ Munnell Hollow

Figure 12a. Total Number of Immature Taxa at Kent Run and Munnell Hollow 


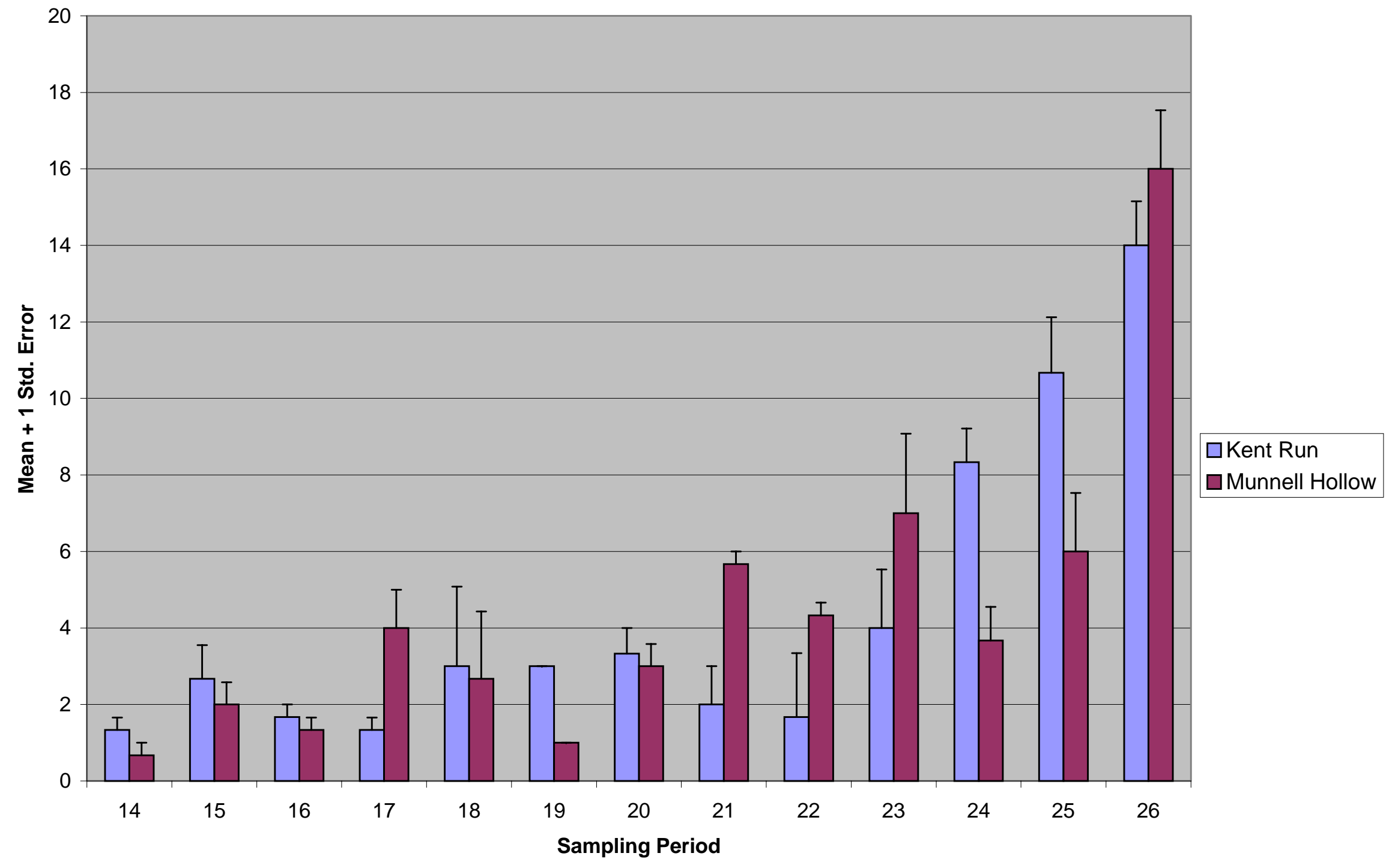

Figure 12b. Total Number of Immature Taxa at Kent Run and Munnell Hollow 


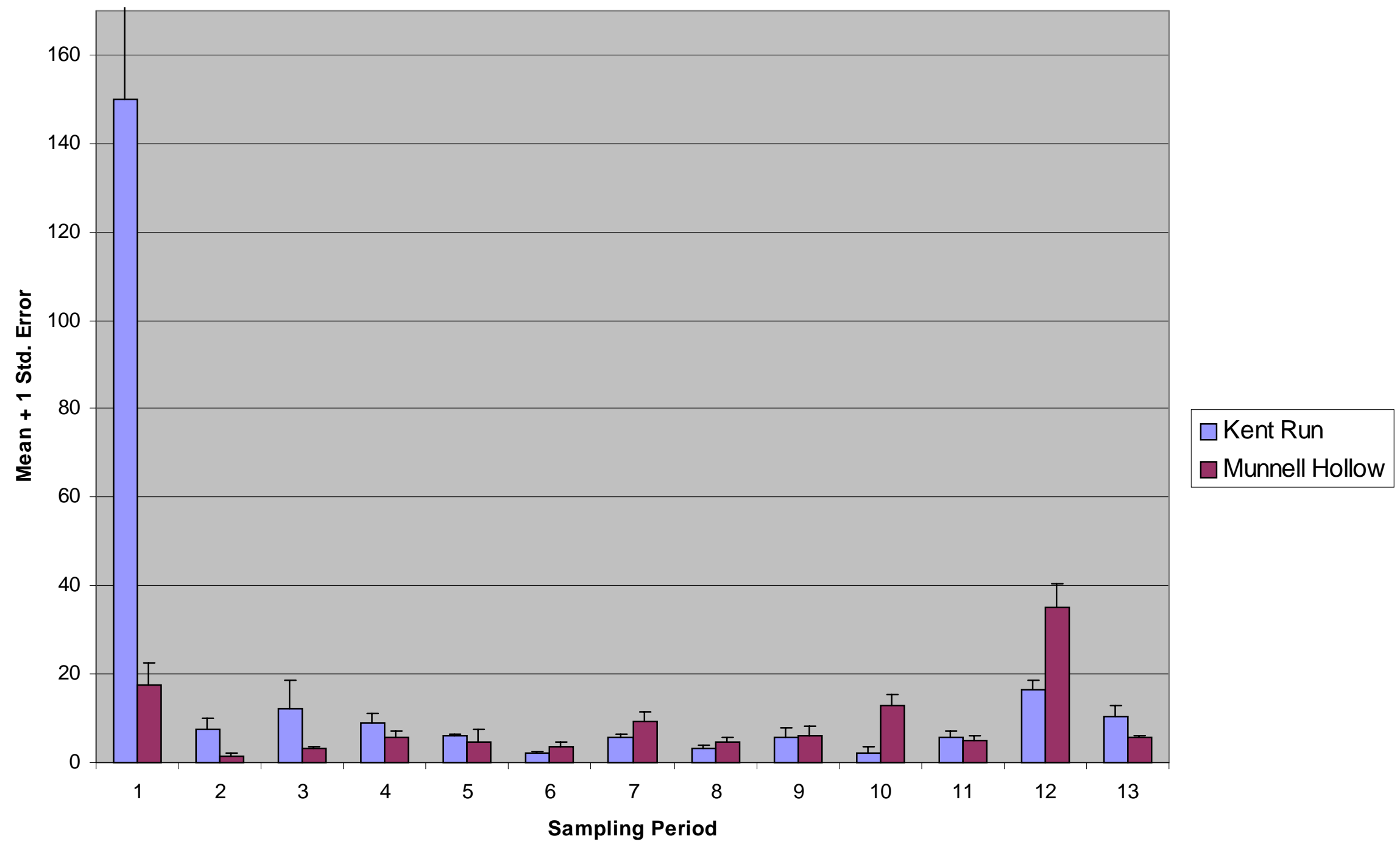

Figure 13a. Total Number of Immature Individuals at Kent Run and Munnell Hollow 


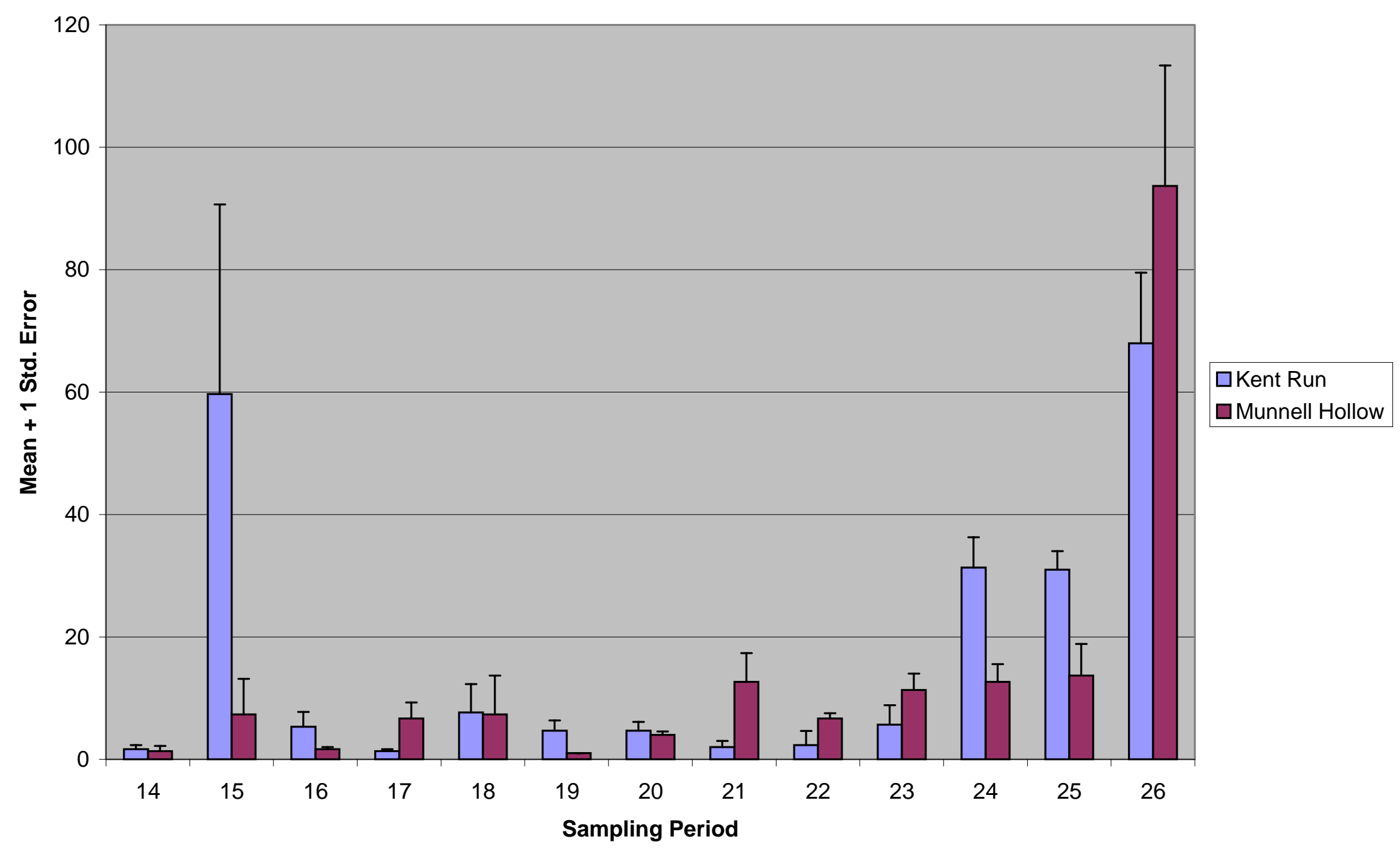

Figure 13b. Total Number of Individuals 


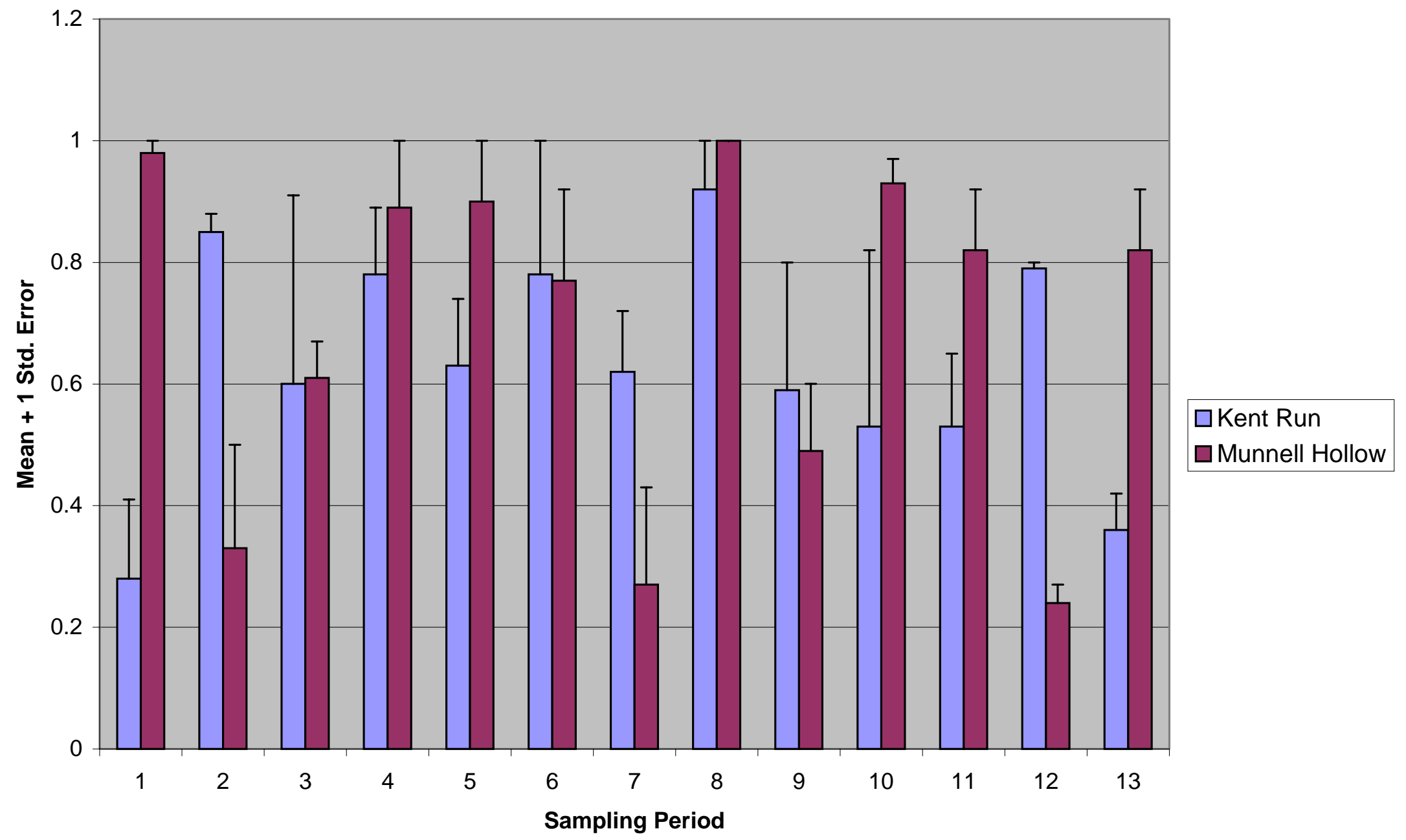

Figure 14a. Proportion of Immature EPT Taxa (x 100 = Percentage) at Kent Run and Munnell Hollow 


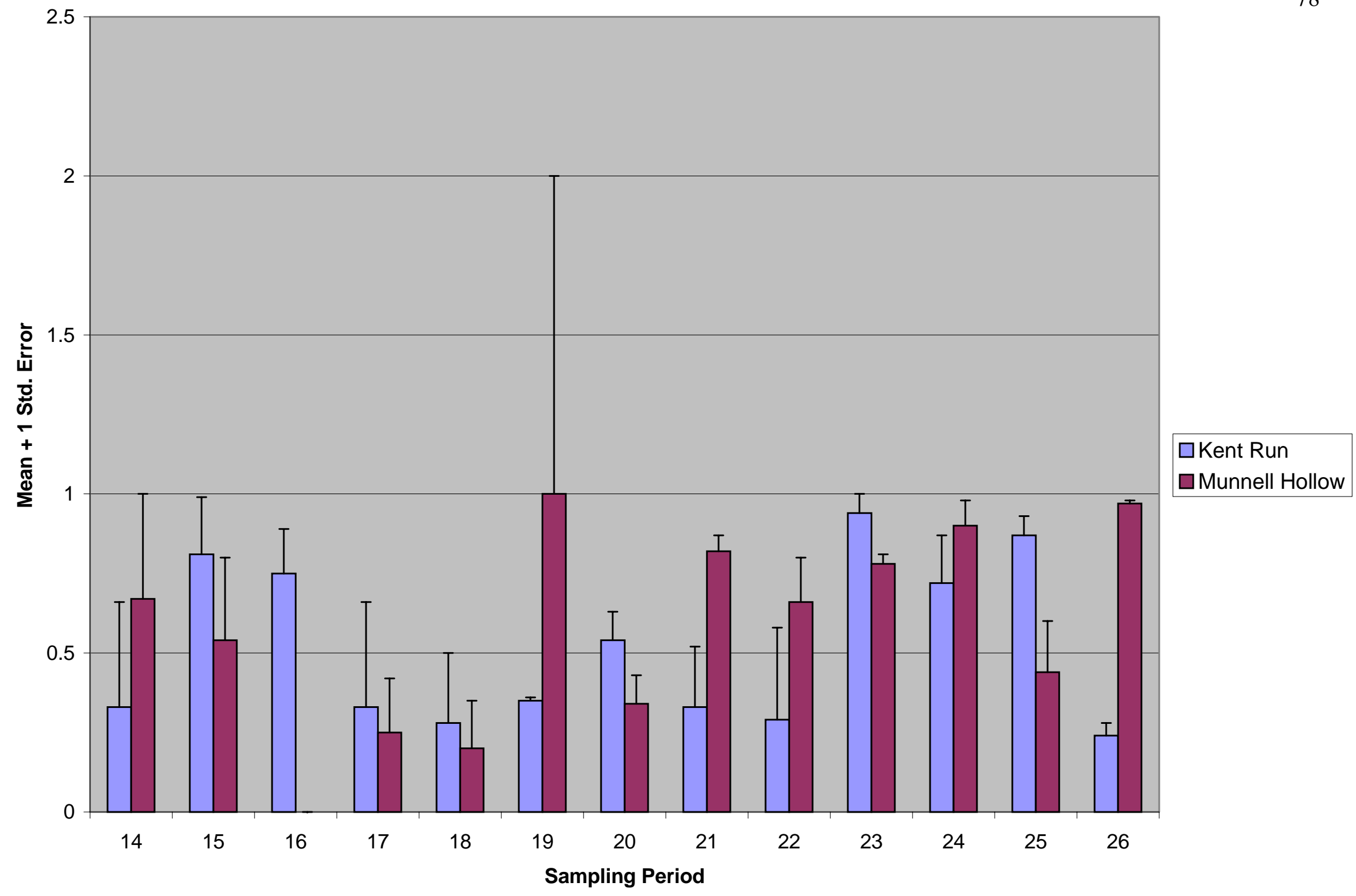

Figure 14b. Proportion of Immature EPT Taxa (x 100 = Percentage) at Kent Run and Munnell Hollow 


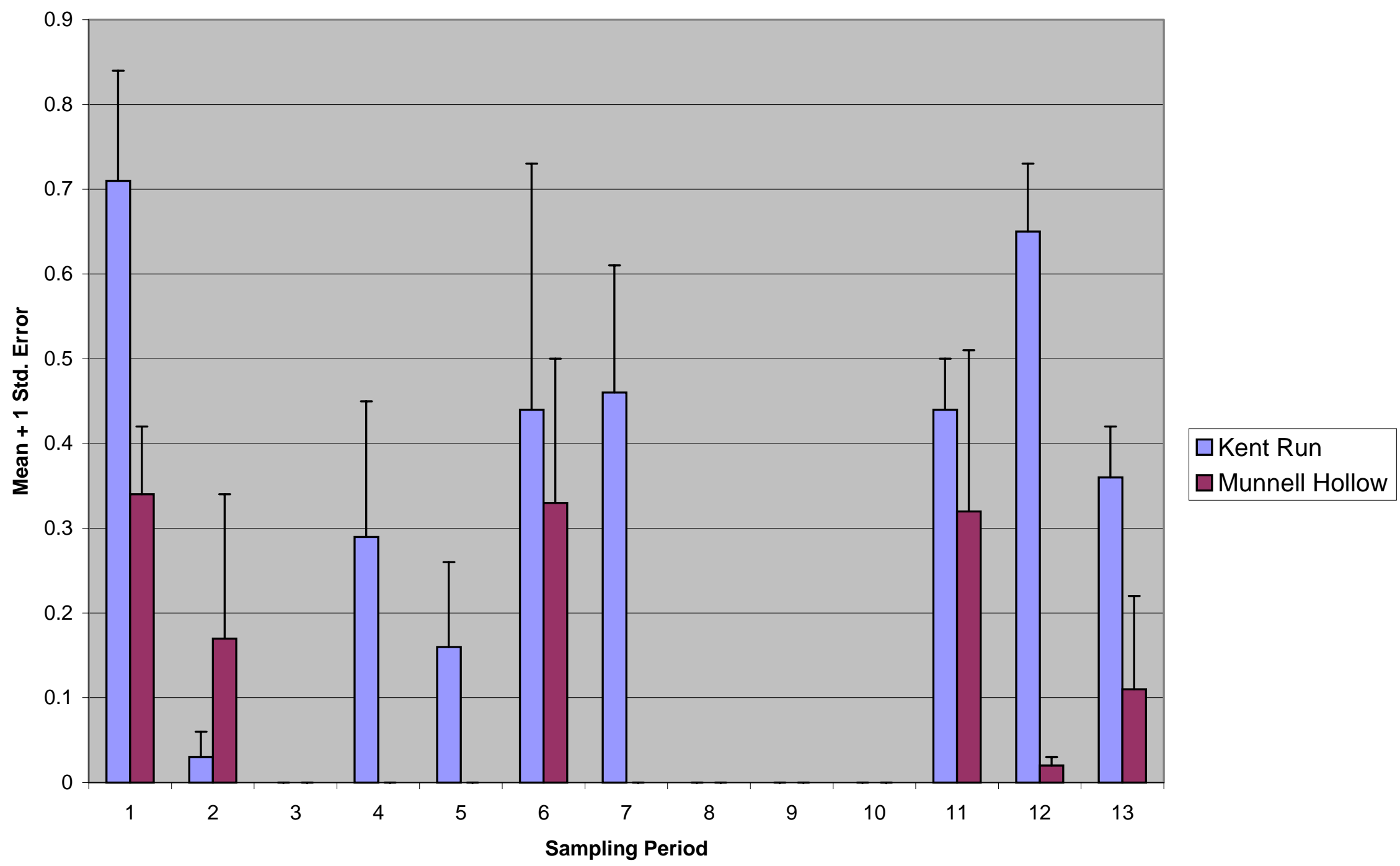

Figure 15a. Proportion of Immature Collector-Filterers (x $100=$ Percentage) at Kent Run and Munnell Hollow 


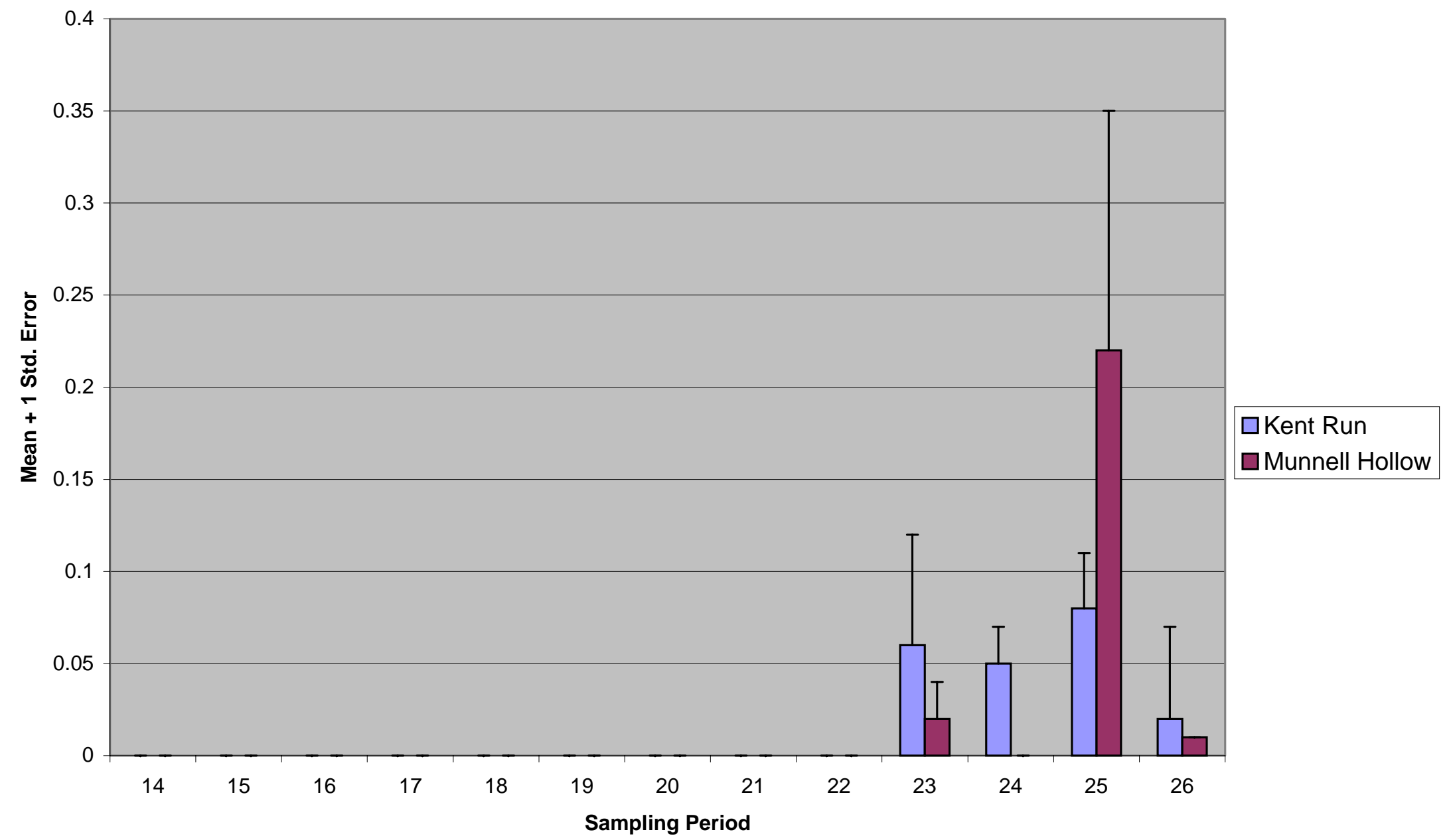

Figure 15b. Proportion of Immature Collector-Filterers (X $100=$ Percentage) at Kent Run and Munnell Hollow 


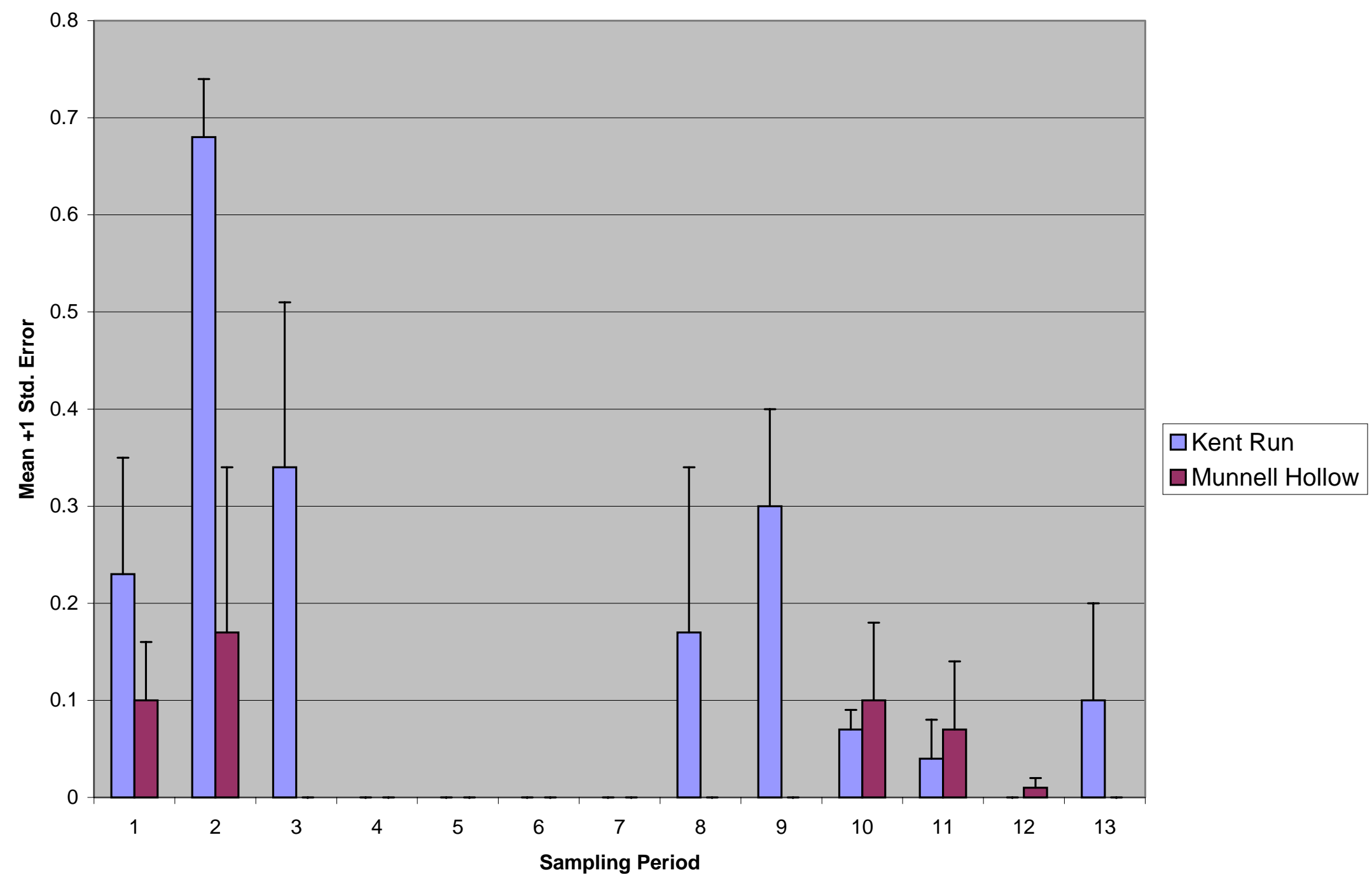

Figure 16a. Proportion of Immature Collector-Gatherers (X $100=$ Percentage) at Kent Run and Munnell Hollow 


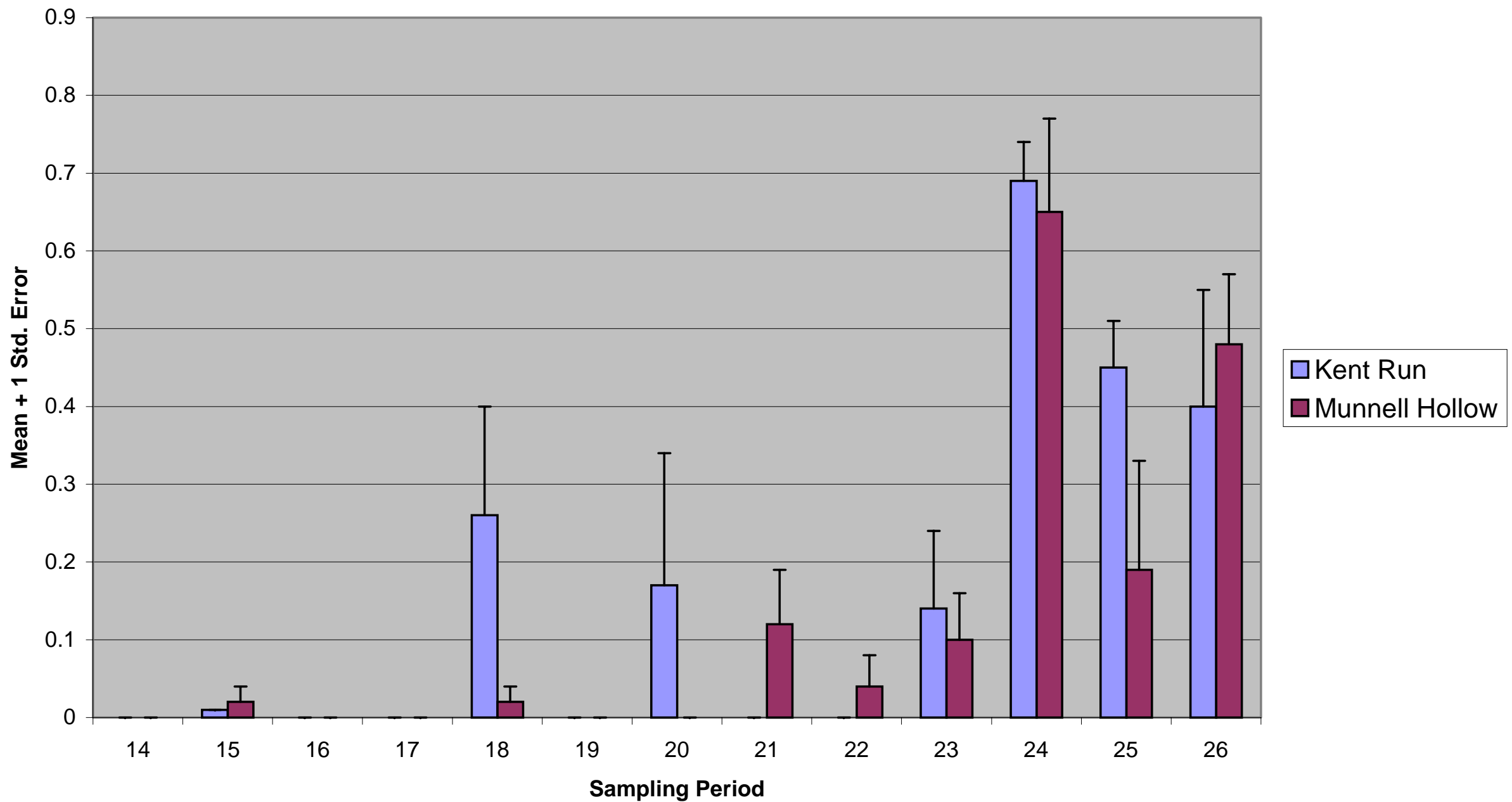

Figure 16b. Proportion of Collectors-Gatherers (x $100=$ Percentage) at Kent Run and Munnell Hollow 


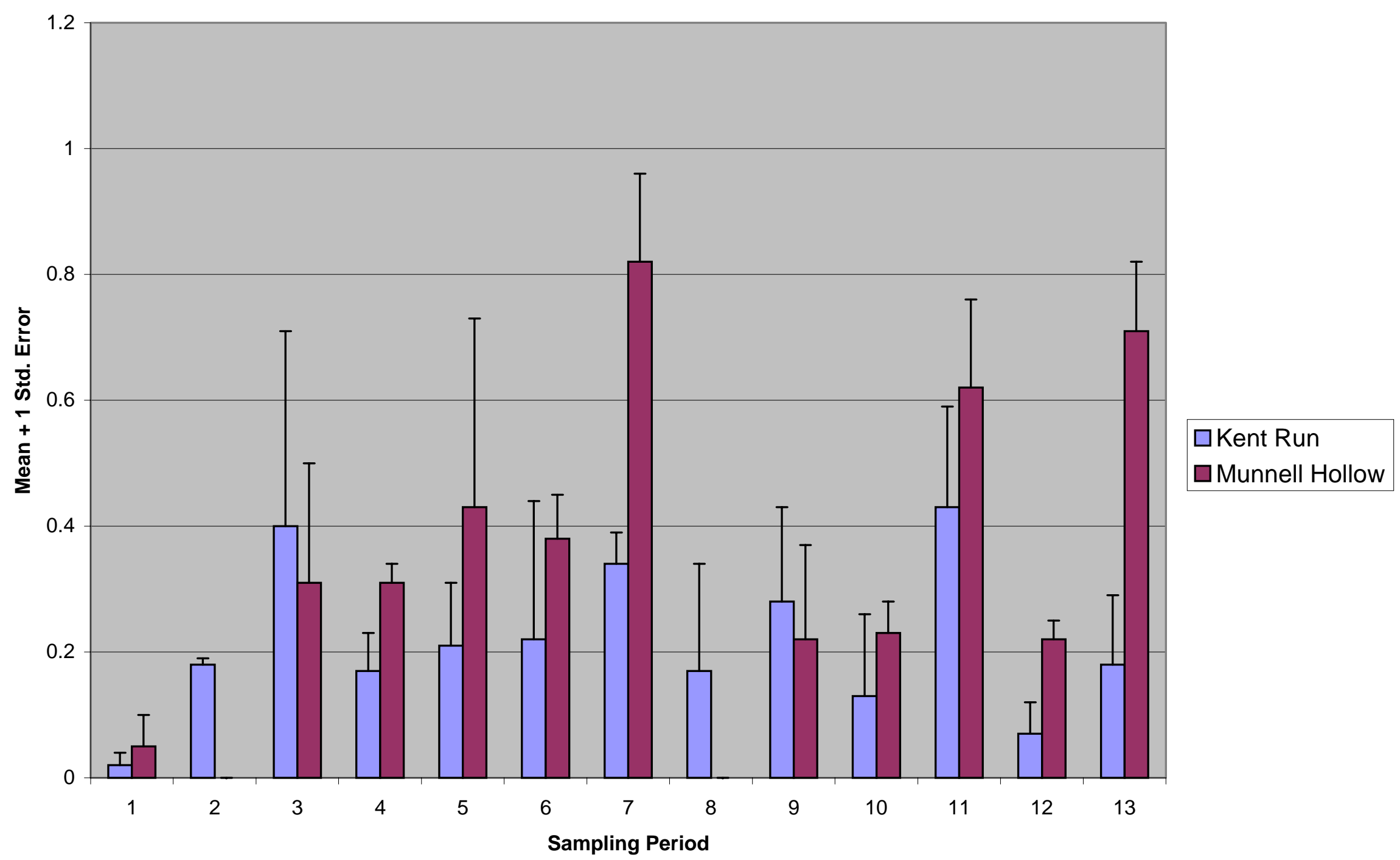

Figure 17a. Proportion of Immature Predators $(x 100=$ Percentage) at Kent Run and Munnell Hollow 


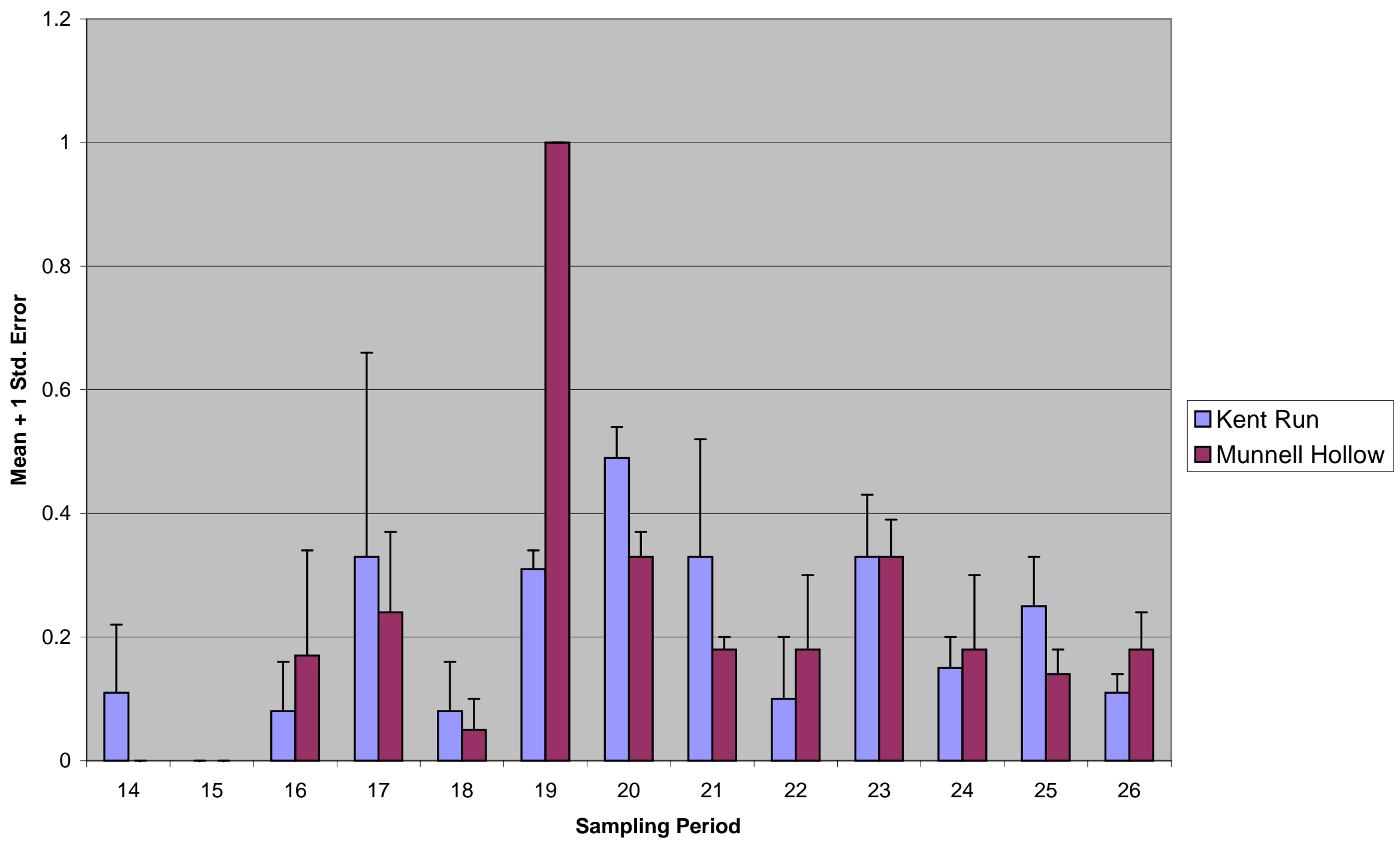

Figure 17b. Proportion of Immature Predators $(x 100=$ Percentage) at Kent Run and Munnell Hollow 


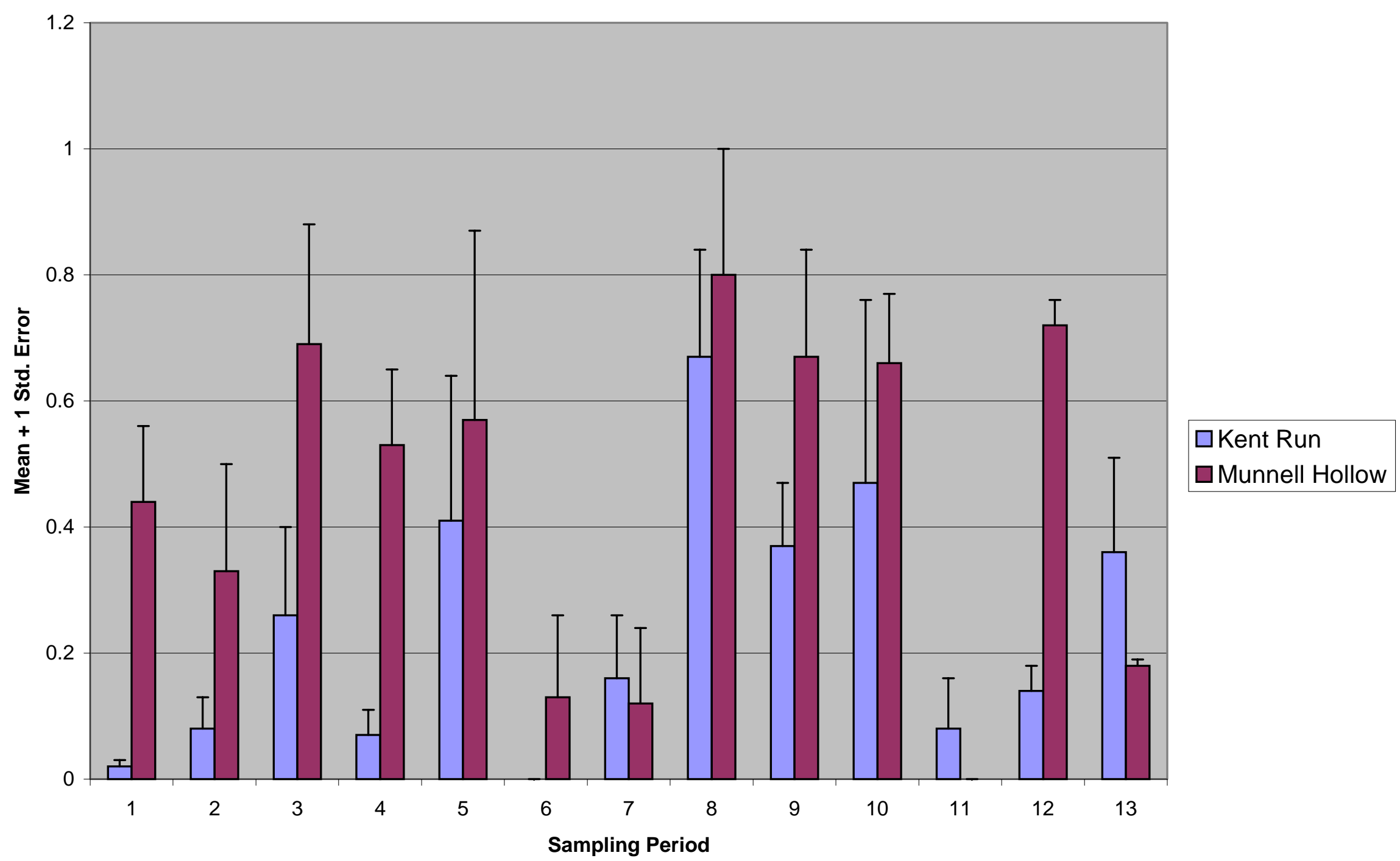

Figure 18a. Proportion of Immature Shredders $(\times 100=$ Percentage) at Kent Run and Munnell Hollow 


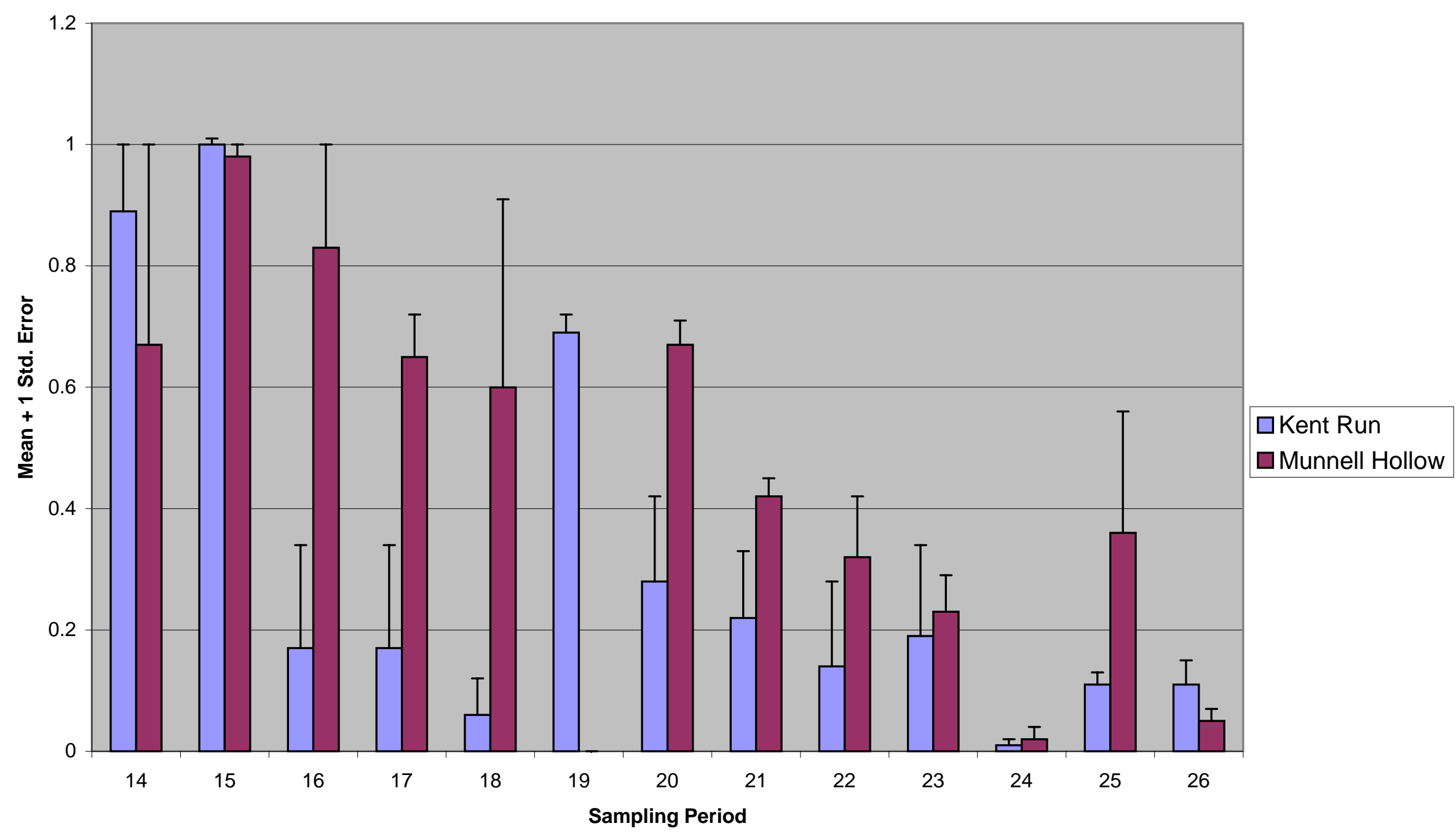

Figure 18b. Proportion of Immature Shredders (x $100=$ Percentage) at Kent Run and Munnell Hollow 


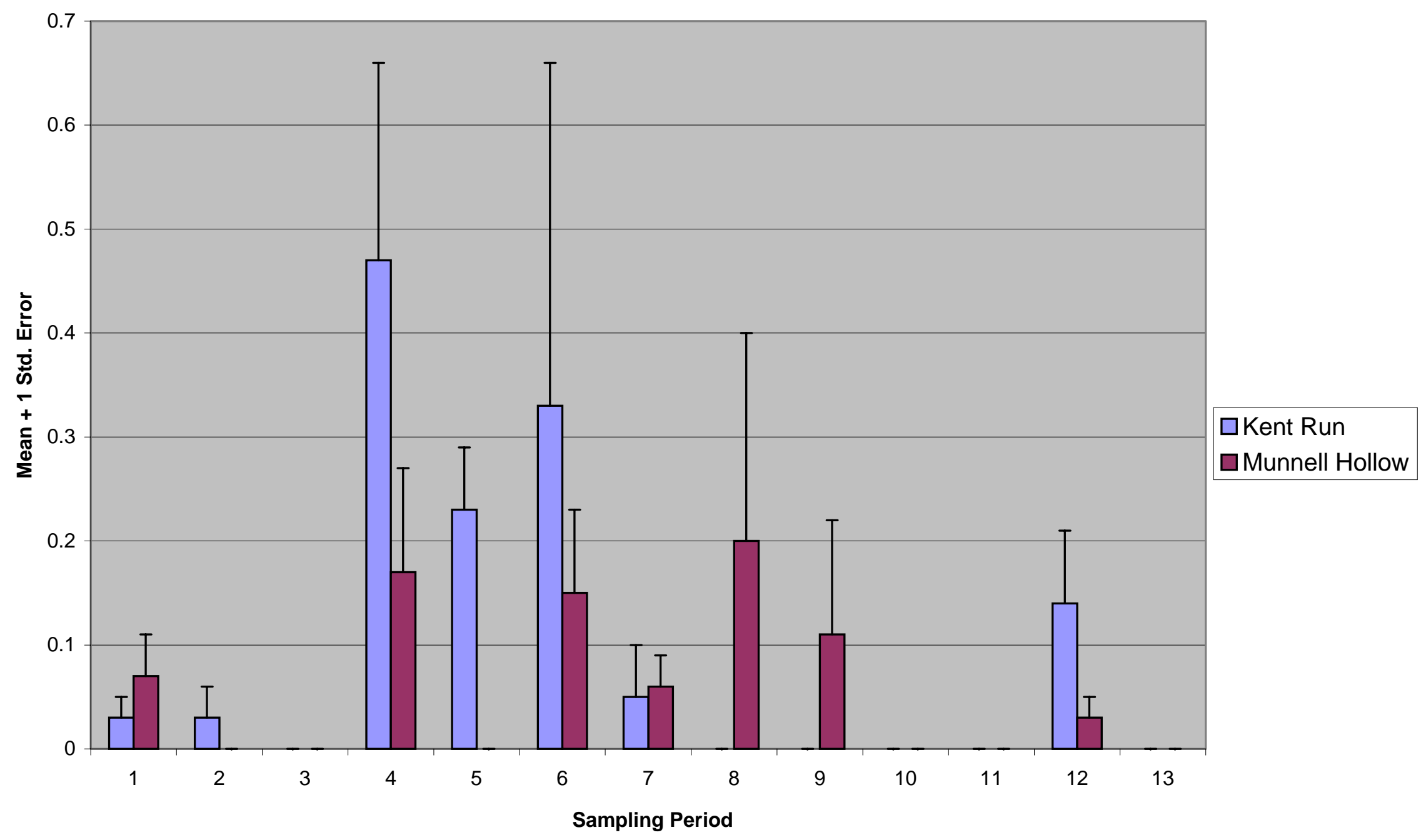

Figure 19a. Proportion of Immature Scrapers (x $100=$ Percentage) at Kent Run and Munnell Hollow 


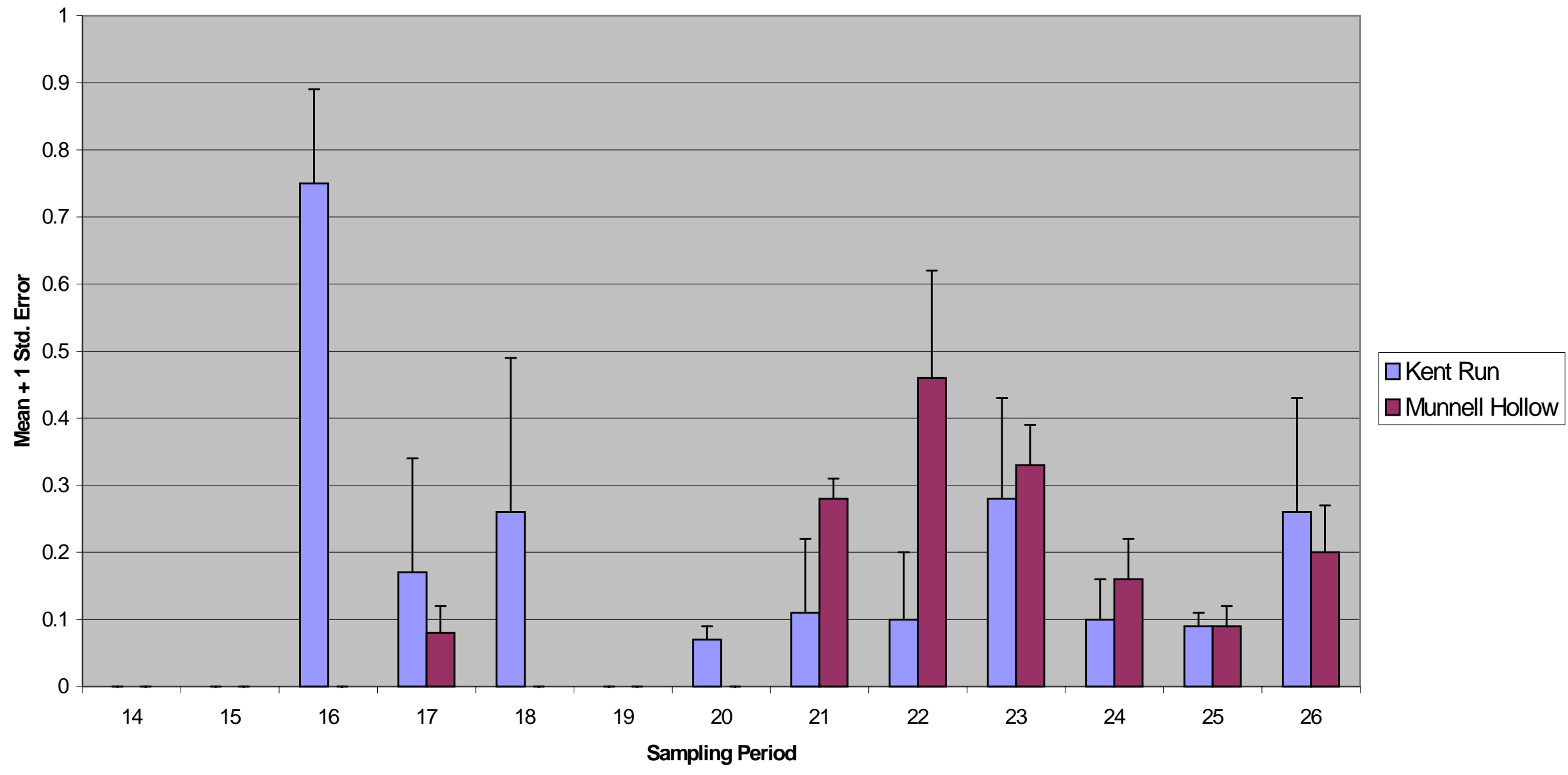

Figure 19b. Proportion of Immature Scrapers (x 100= Percentage) at Kent Run and Munnell Hollow 


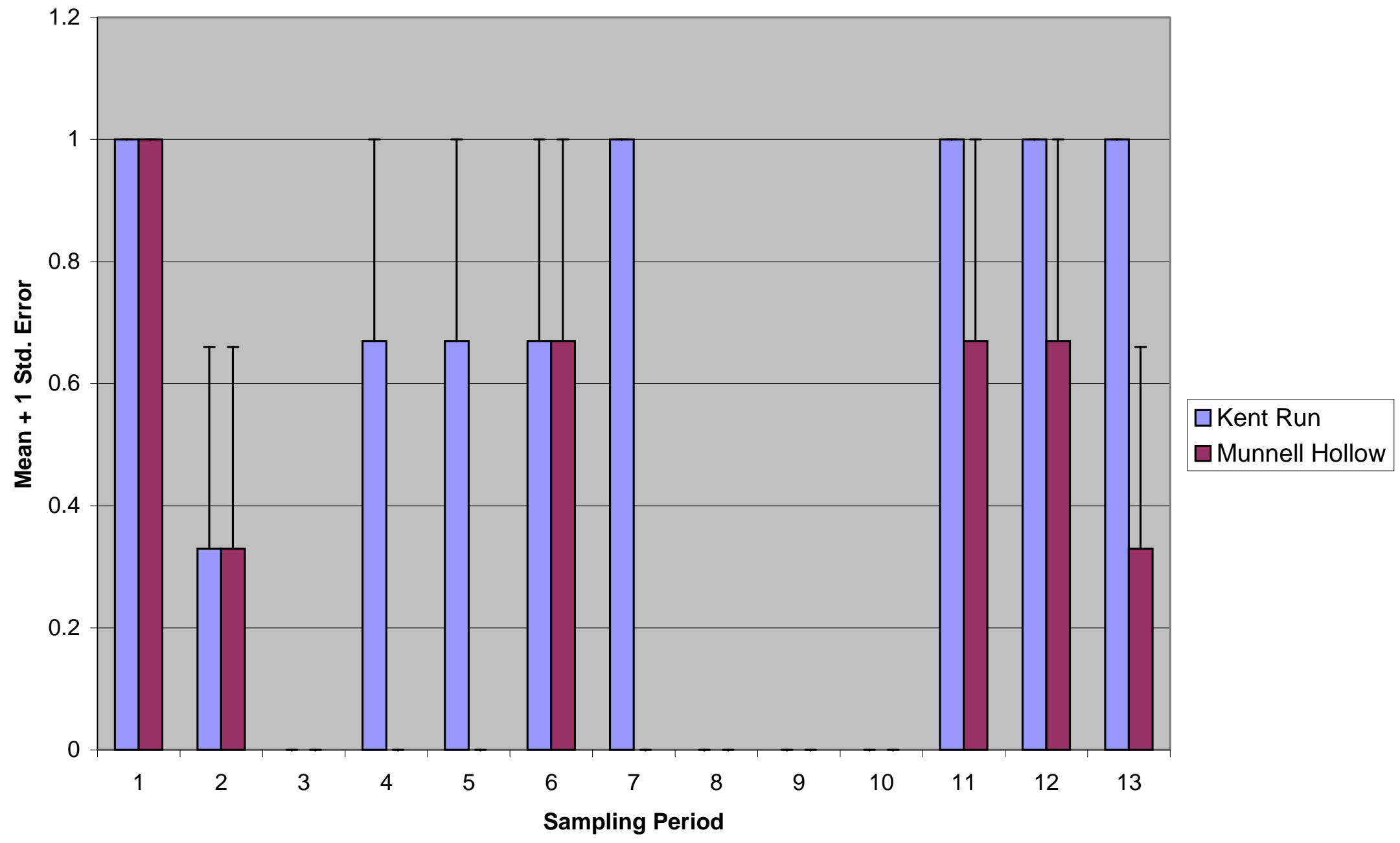

Figure 20a. Number of Immature Collector Filterers at Kent Run and Munnell Hollow 


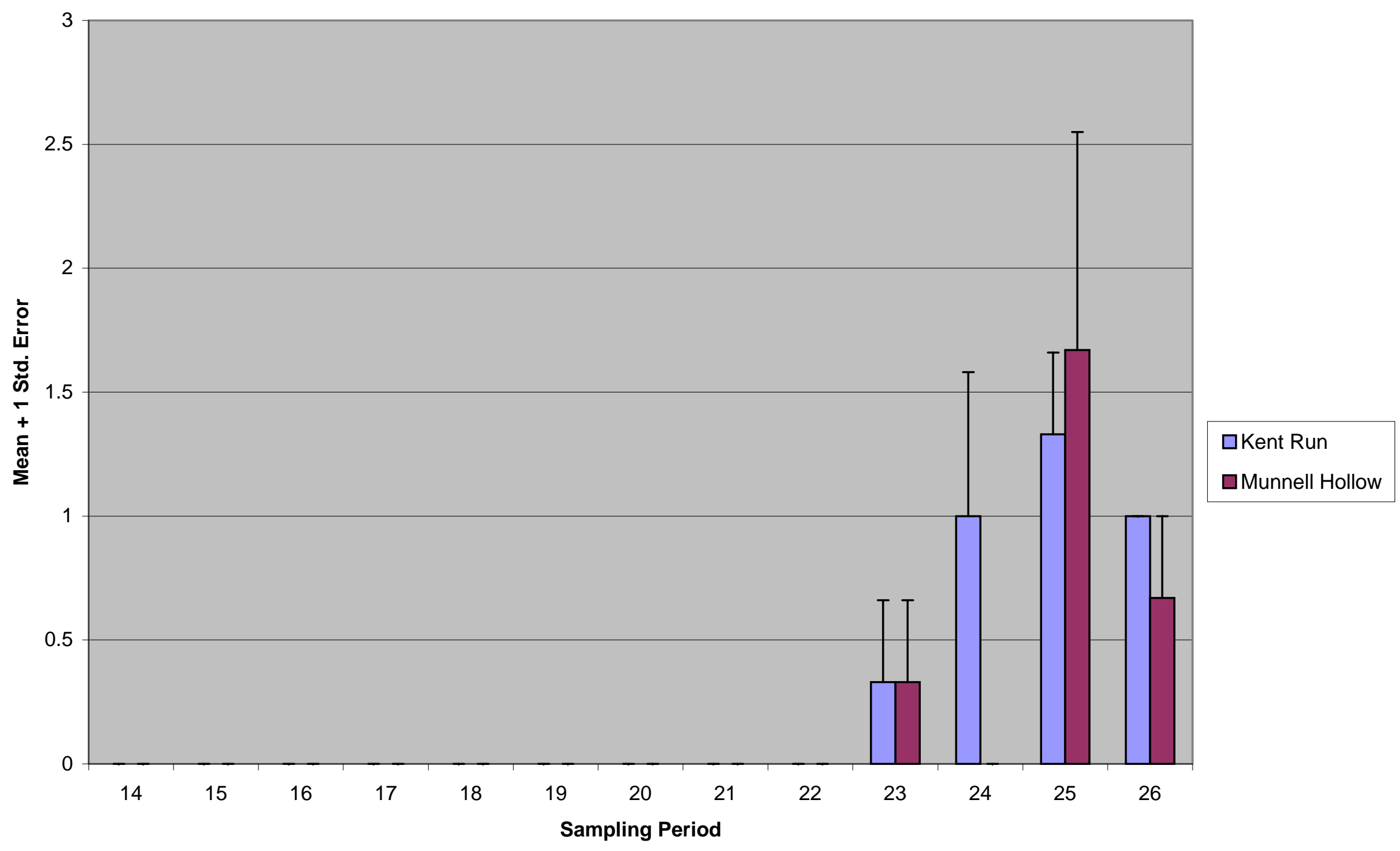

Figure 20b. Number of Immature Collector Filterers at Kent Run and Munnell Hollow 


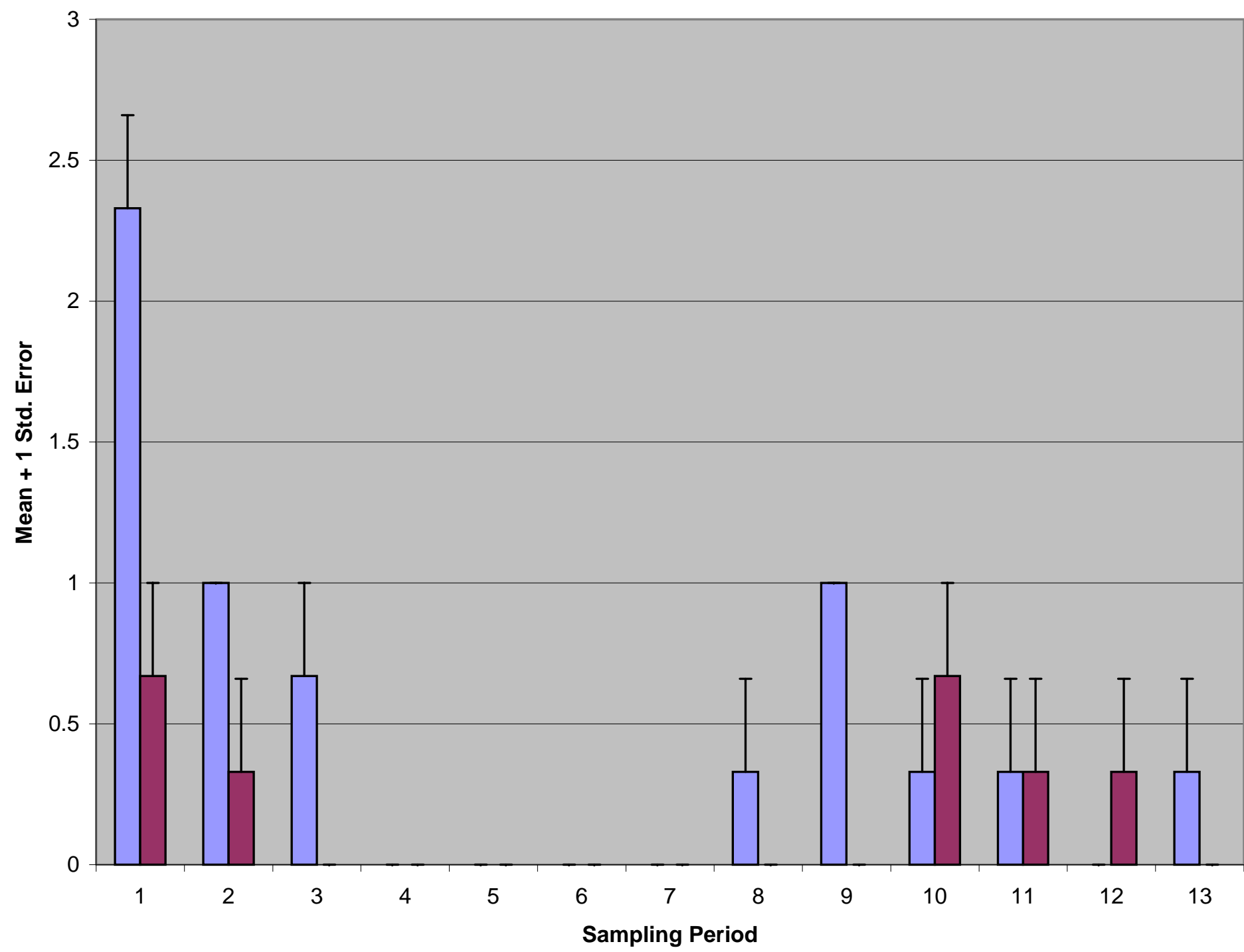

$\square$ Kent Run

$\square$ Munnell Hollow

21a. Number of Immature Collectors-Gatherers at Kent Run and Munnell Hollow 


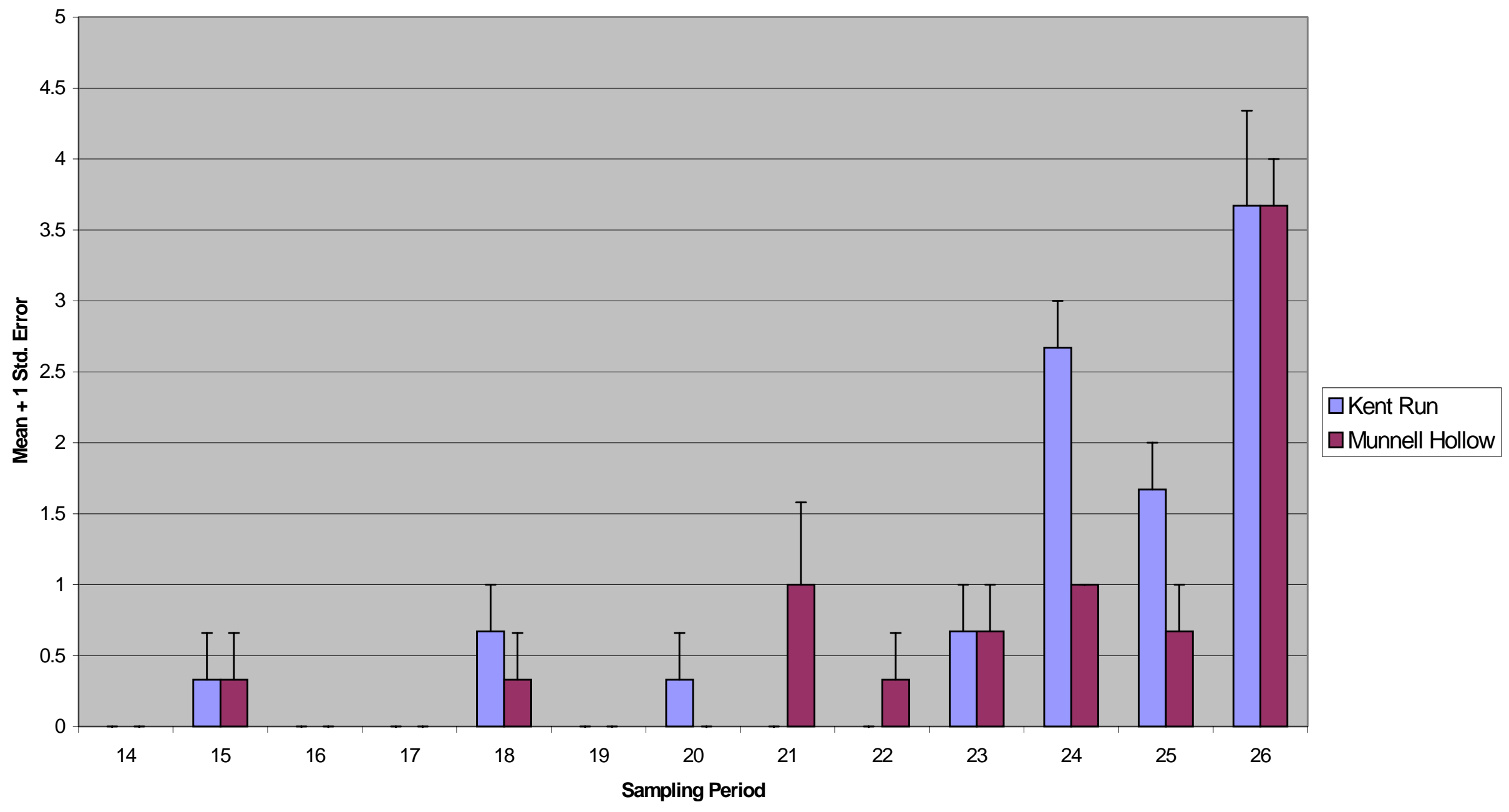

Figure 21b. Number of Immature Collector-Filterers at Kent Run and Munnell Hollowell Hollow 


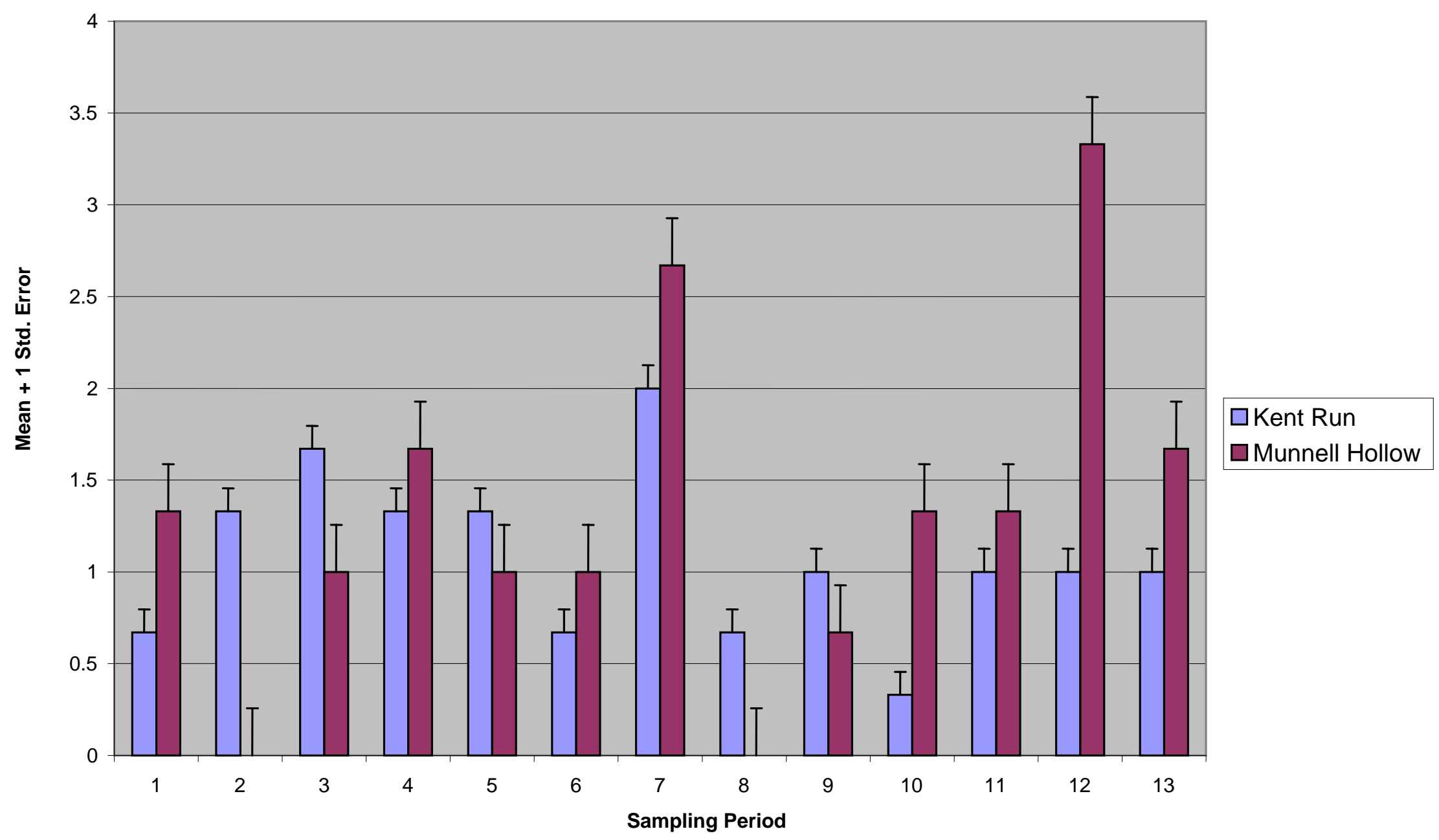

Figure 22a. Number of Immature Predators at Kent Run and Munnell Hollow 


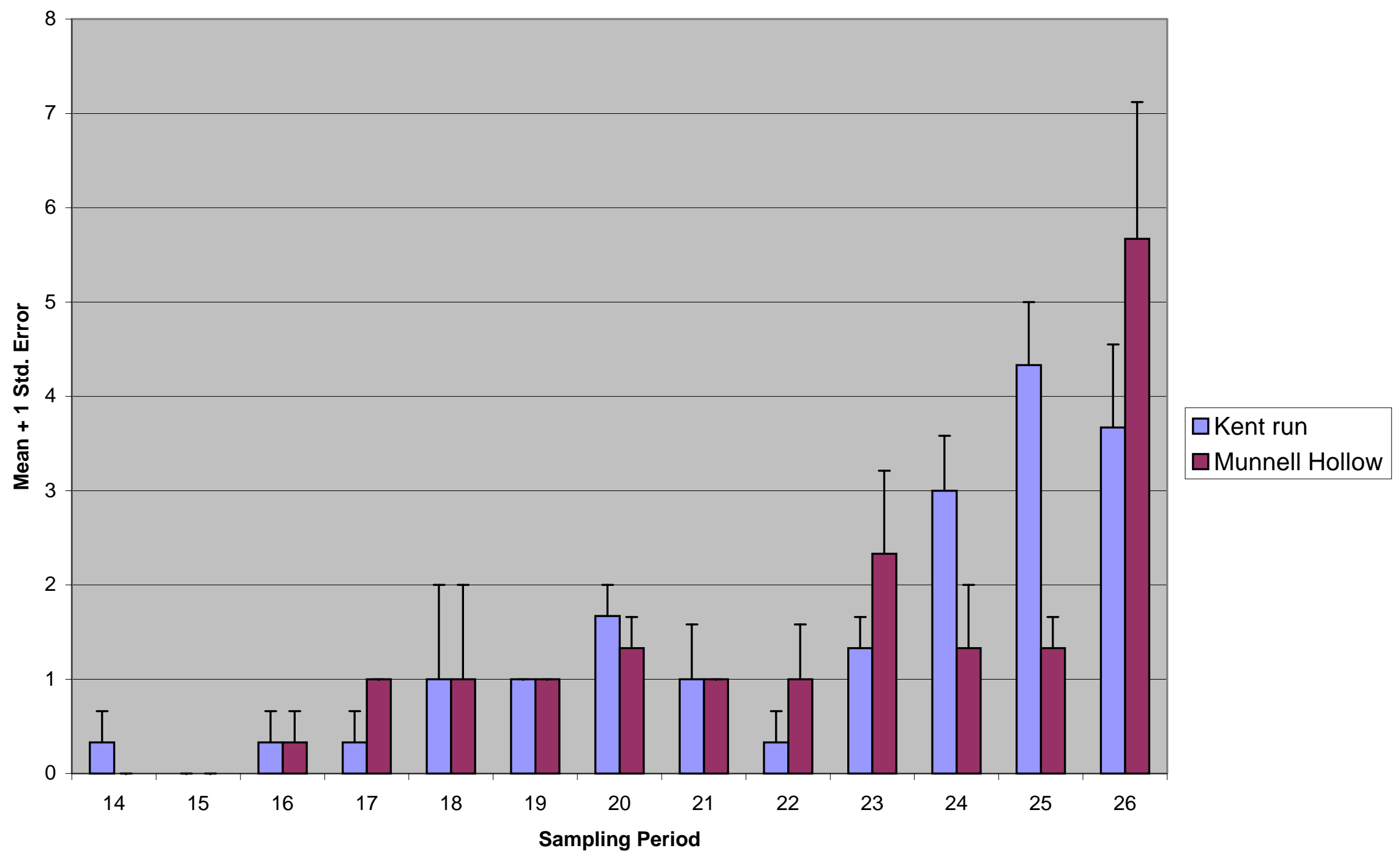

Figure 22b. Number of Immature Predators at Kent Run and Munnell Hollow 


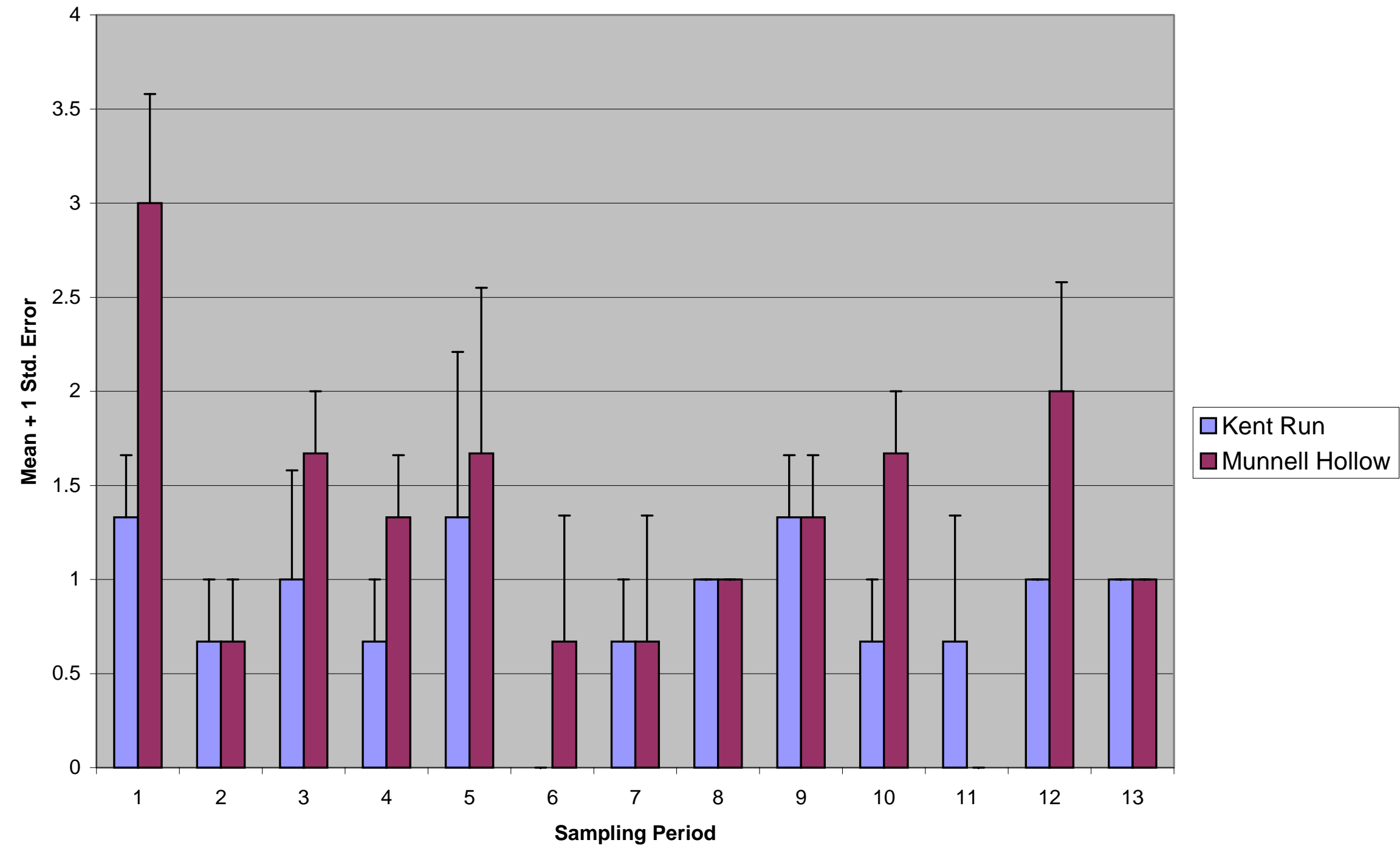

Figure 23a. Number of Immature Shredders at Kent Run and Munnell Hollow 


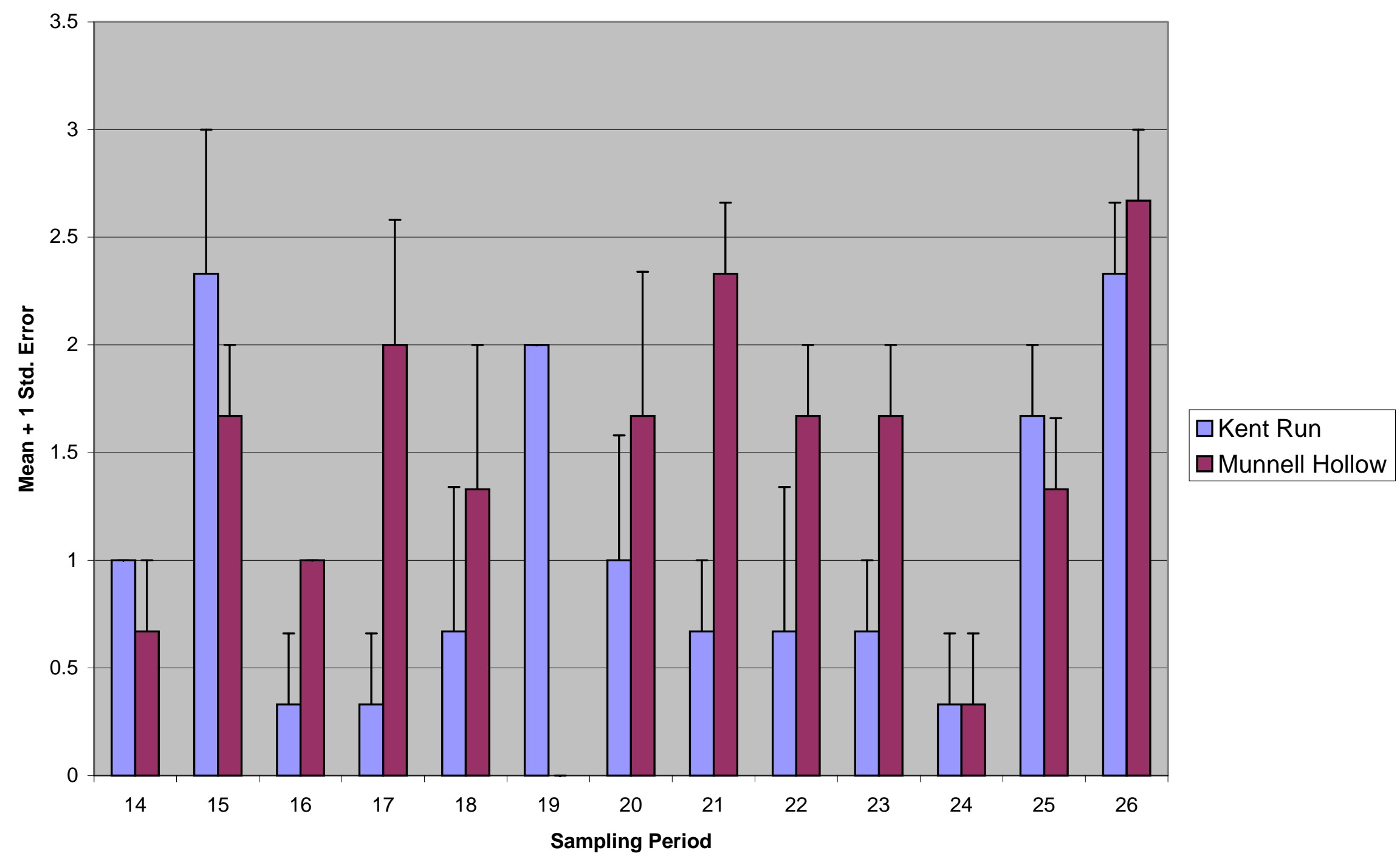

Figure 23b. Number of Immature Shredders at Kent Run and Munnell Hollow 


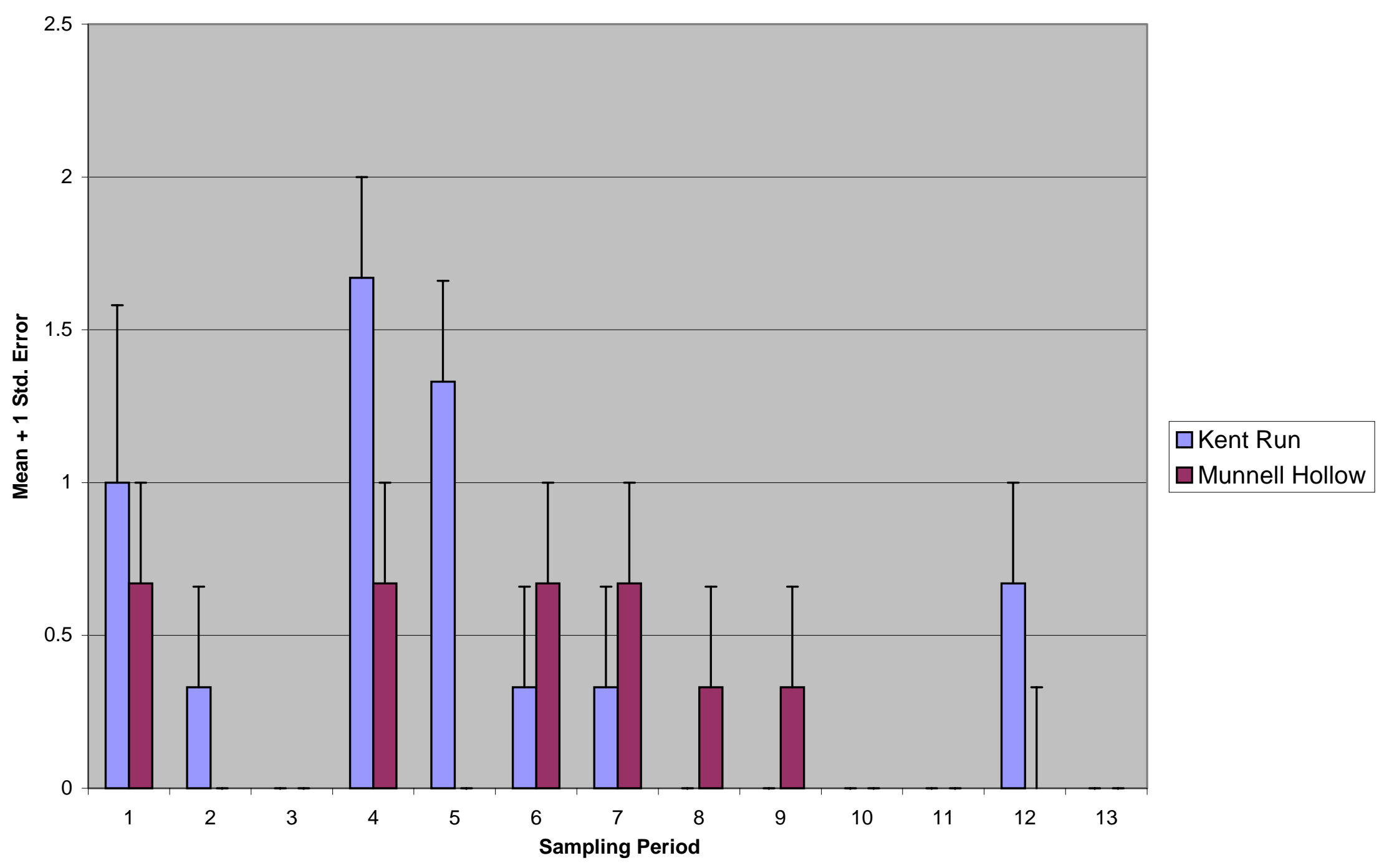

Figure 24a. Number of Immature Scrapers at Kent Run and Munnell Hollow 


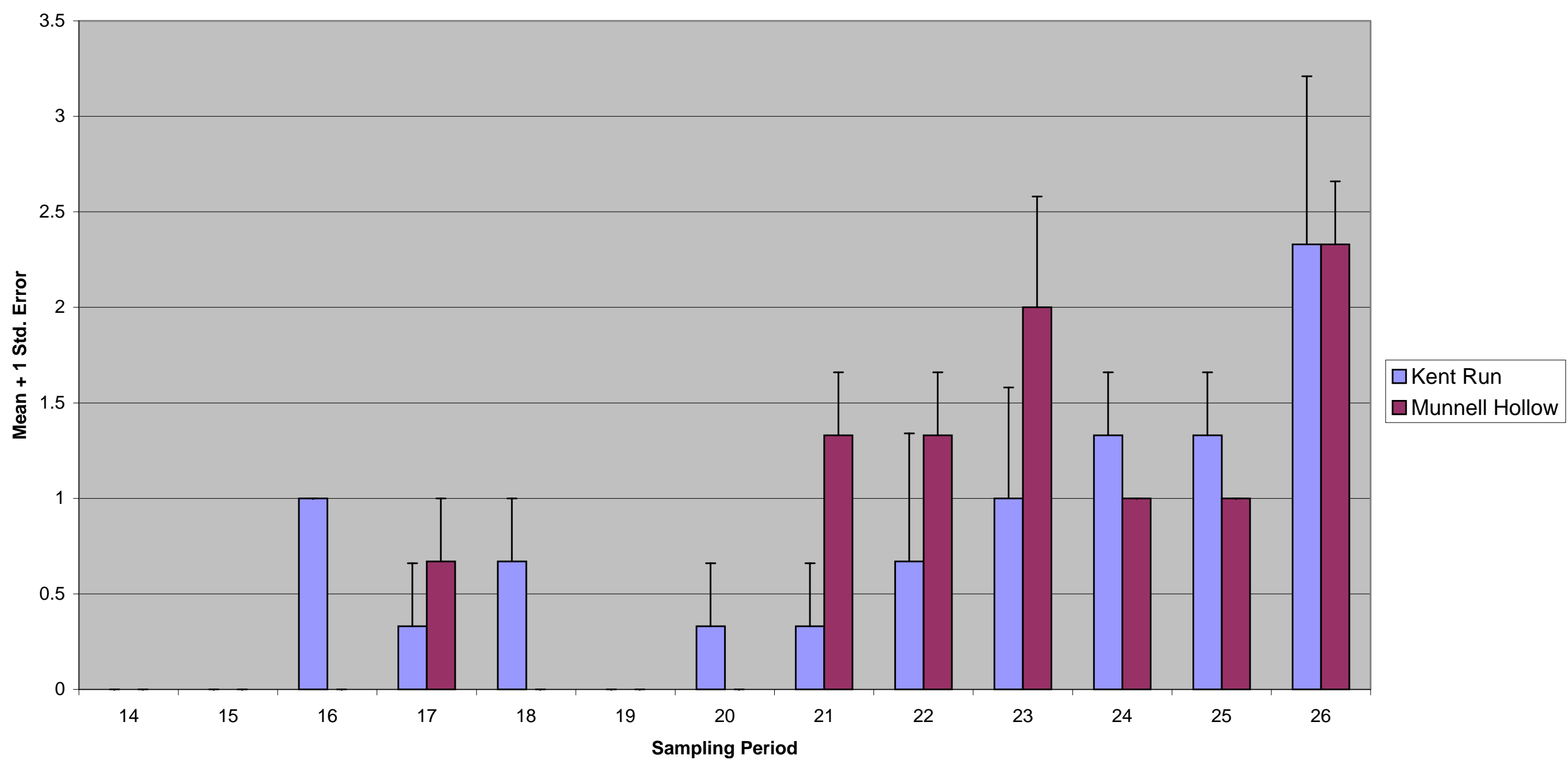

Figure 24b. Number of Immature Scrapers at Kent Run and Munnell Hollow 


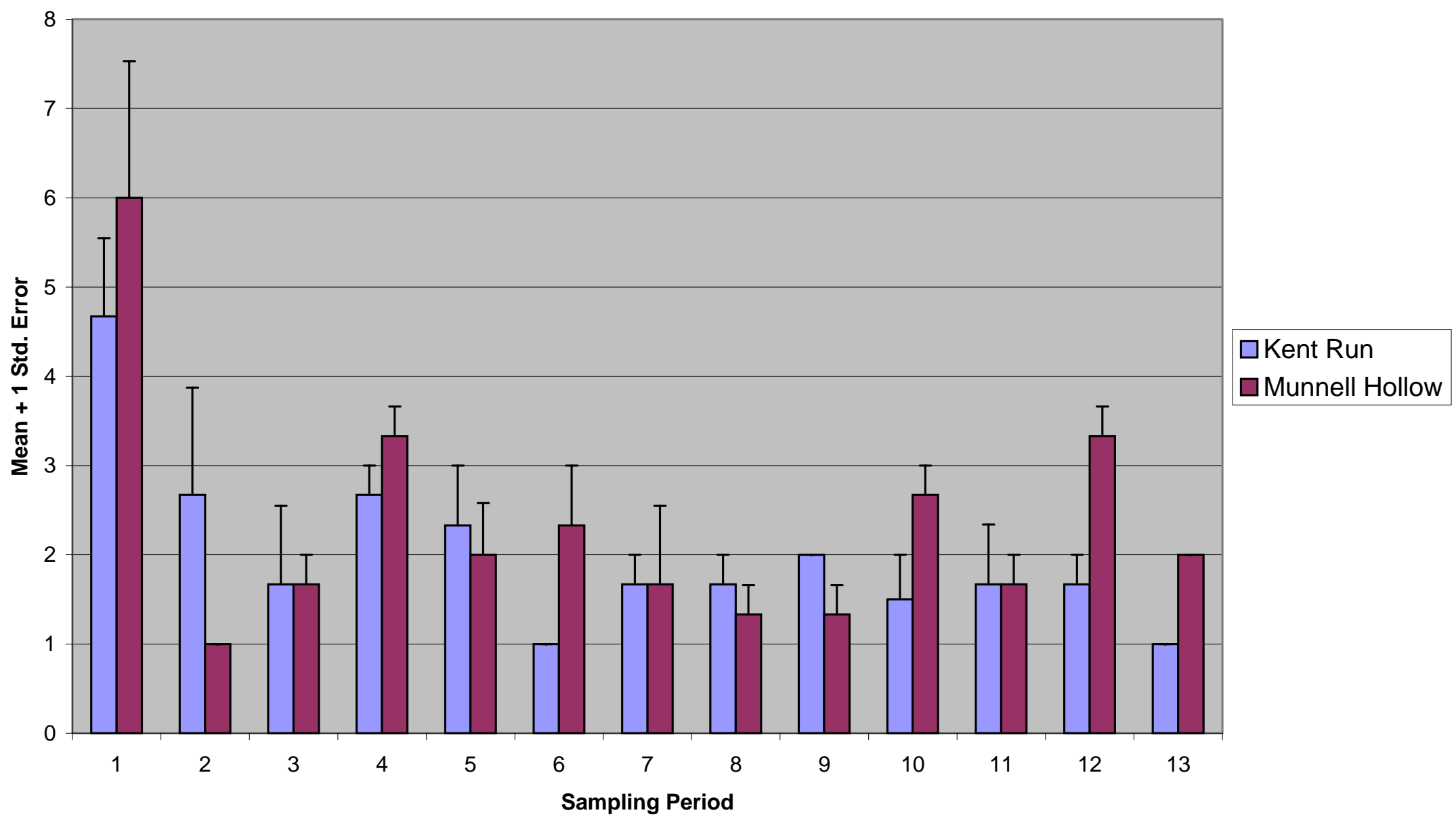

Figure 25a. Number of EPT at Kent Run and Munnell Holow 


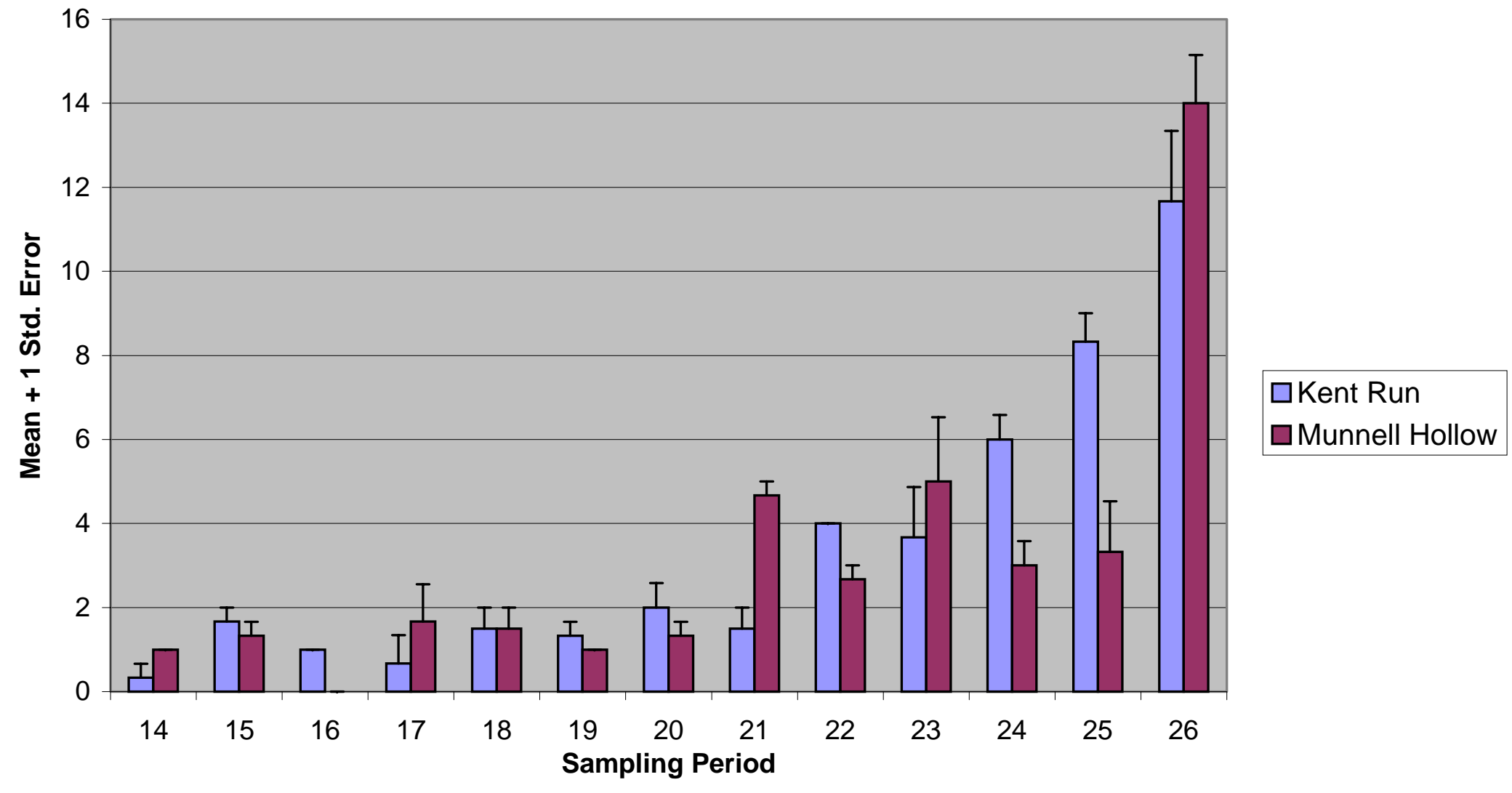

Figure 25b. Number of EPT Taxa at Kent Run and Munnell Hollow 


\section{Discussion}

In order to adequately describe the distribution and inter-relationships of invertebrates, investigations must be conducted on a year-round basis (Cummins 1962). By looking at the invertebrates sampled in conjunction with other headwater factors such as water parameters, functional feeding groups, the River Continuum Concept, and community metric analyses by repeated measures ANOVA, an understanding of the stream community interrelationships becomes apparent.

\section{Water Parameters}

There was a significant difference between streams in the six water parameters measured. Dissolved oxygen, maximum, and minimum temperature were higher at Munnell Hollow and hardness, $\mathrm{pH}$, and velocity were higher at Kent Run (Table 2).

\section{Dissolved oxygen}

The influence of the various water parameters is partly responsible for the invertebrates found in the stream. Dissolved oxygen concentrations in the same stream are not uniform within or between stream reaches. The side flow of ground water or the upwelling of water from the hyporheic zone may create areas where the dissolved oxygen is significantly less than that of surrounding waters (Stanford and Ward 1988, 1993). This lack of uniformity is the reason that least means squares were used to calculate the value of the variable for each stream. 
The drought conditions of 1999 resulted in the cessation of surface flow and the formation of isolated pools. Dissolved oxygen readings were generally lower than the pre-or post drought readings. A reduction in dissolved oxygen levels in pools occurs where current and turbulence do not allow for the reestablishment of oxygen levels (Larimore et al. 1959, Iverson et al. 1982, Ladle and Bass 1981, Canton et al. 1984).

Dissolved oxygen is transported across gills and other respiratory structures of aquatic organisms by diffusion and the rate is dependent upon the concentration gradient (Allan 1995). Oxygen in the water that is in contact with the respiratory structures of the insect becomes depleted by respiratory uptake and is renewed by the current. Many invertebrate taxa (e.g. some Plecoptera nymphs, some Diptera larvae, and Trichoptera larvae and pupae) rely solely on the integument for respiration, and because they have no capacity to generate body movement, rely on the current to bring new oxygen. Other invertebrates (Ward 1992) rely on tracheal gills (Ephemeroptera nymphs, Odonata nymphs, Megaloptera larvae, Neuroptera larvae, some Diptera larvae, many Trichoptera larvae, and a few Trichoptera pupae); excursions to the surface (most Hemiptera nymphs and adults, some Megaloptera larvae, a few Lepidoptera larvae, many Coleoptera larvae and adults, and some Diptera larvae and pupae); extensions of respiratory tubes to the surface (a few Diptera larvae); ability to tap plant aerenchyma (a few Coleoptera larvae, pupae, and adults, a few Diptera larvae and pupae, and a few Lepidoptera); physical gills (most Hemiptera nymphs and adults, many Coleoptera larvae and adults, and a few Lepidoptera larvae); hair plastron (a few Hemiptera adults and some Coleoptera adults); and spiracular gills (a few Coleoptera larvae and pupae and some Diptera pupae). 
A number of aquatic insects perform ventilatory movements (Allan 1995).

Ephemerella sp. Walsh (Trichoptera: Ephemerellidae) and thus generate water exchange by rapidly moving the gills back and forth. Some Plecoptera nymphs do "push-ups" if ambient water levels decline (Knight and Gaufin 1966). The gills of some burrowing species of mayflies move water through their tunnels. The gills beat with a frequency inversely proportional to the oxygen concentration in the burrow (Wingfield 1939 and Eriksen 1968). Diel changes in the positioning of the trichopteran Glossosoma nigrior Banks (Glossosomatidae) were characterized by an increase in the proportion of individuals on the front of stones in the stream where the current velocity was lower and the water temperature higher. At higher velocities and lower water temperatures, the larvae are more equally distributed on the top, front, and sides of the stones (Kovalak 1976). All above species were found in this study.

\section{Hardness and pH}

Hardness is higher in limestone-rich areas (Costello et al. 1984). The geology of Ryerson Station State Park dates to the Permian period of the Paleozoic era (250 to 290 million years ago). The main rock types or deposits are cyclic sequences of shale, sandstone, limestone, and coal (Barnes and Sevon 1996). Evidently, the greater hardness at Kent Run reflects the extent of the limestone strata in the stream substrate.

There was a significant difference between the two streams for total hardness (Figure 4) and pH (Figure 7); both were higher at Kent Run. Neel (1973) noted that certain orders of insects such as Ephemeroptera, Coleoptera, and Diptera develop better in soft waters of lower alkalinity while Plecoptera and Trichoptera develop better in hard, more 
alkaline streams. The Ryerson study seems to confirm Neel's findings. Number of taxa of Ephemeroptera, Coleoptera, and Diptera were higher at Munnell Hollow (a soft water, less alkaline stream) as well as the total percentage of Ephemeroptera and Diptera. For Kent Run (a hard water, more alkaline stream) the number of taxa of Plecoptera and Trichoptera was higher in addition to the total percentage of Plecoptera and Trichoptera.

\section{Maximum and minimum temperature}

Headwater stream temperatures are generally within $1{ }^{\circ} \mathrm{C}$ of the mean annual air temperature of the region (Allan 1995). In very heavily shaded streams such as Kent Run and Munnell Hollow, the transfer of heat from the air and flow from groundwater are more important than direct solar radiation in governing stream temperature (Hauer and Lamberti 1996).

Aquatic insects respond to the entire temperature regime of a stream. This includes not only diel and seasonal ranges, but also the timing and duration of thermal events (Ward 1992). Hynes (1970b) stated that it is the pattern of temperature change rather than the absolute temperature attained that is the most important factor controlling species distribution.

Maximum and minimum temperature readings were significantly higher at Munnell Hollow (Figures 5 and 6). These results are questionable, however, due to the inaccurate setting of the maximum-minimum thermometers. Mackay (1969) found that water temperatures nearer the source were generally lower in summer and higher in winter than at stations further downstream. During this study, even though sampling sites were randomly selected, more of the sampling areas along Munnell Hollow were nearer the 
origin of the stream (personal observation) than were the sampling areas along Kent Run. In addition, Munnell Hollow is a smaller first order stream, resulting in overall lower maximum and minimum temperatures because of the moderating effect of groundwater.

\section{Velocity}

Current velocity in the same cross-section of a stream varies depending on the location measured with the current meter. Maximum water velocity in a straight section of a stream channel is normally greatest at or near the surface of the water, in the center of the stream channel, with greatly diminished values along the edges and near the bottom (Ward 1992). Since velocity declines exponentially with depth, the mean column velocity is located 0.6 of the distance from the surface of the streambed where many aquatic insects reside (Statzner et al. 1988, Davis and Barmuta 1989, and Wetmore et al. 1990) and this is where measurements were taken in the Ryerson study. Conditions near the surface of the streambed may be hydraulically rough (over irregular stream bottom) with turbulent conditions in the near-bed current microenvironment. Near-bed conditions may also be hydraulically smooth (e.g., over flat blades of macrophytes, flat sheets of bedrock, or over mud or clay bottoms) where there is a "laminar sublayer" consisting of a micro area of nonturbulent water above the stream bottom (Davis and Barmuta 1989).

Current velocity affects the insect's ability to gather food (Wallace and Merritt 1980), meet its respiratory requirements (Knight and Gaufin 1963), avoid competition and predation (Peckarsky 1980b), leave unfavorable environmental conditions (Minshall and Winger 1968), or colonize favorable ones (Minshall et al. 1983b). Immature insects collected in this study have a wide variety of behavioral and morphological adaptations to 
current. Leptophlebia cupida (Say) (Ephemeroptera: Leptophlebiidae) uses positive rheotaxis to reduce accidental dislodgement and counter downstream displacement. Baetis flavistriga McDunnough (Ephemeroptera: Baetidae) nymphs have a fusiform shape and smooth contour to offer the least resistance to the current. Rhyacophila fuscula (Walker) (Trichoptera: Rhyacophilidae) has claws and hooks to reduce the chances of dislodgement. Epeorus pleuralis (Banks) and E. vitrea (Walker) (Ephemeroptera: Heptageniidae) are dorso-ventrally flattened to occupy the boundary layer of reduced waterflow found adjacent to the surface of rocks in the stream. Stenelmis lateralis Sand (Coleoptera: Elmidae) utilizes small size to reside in the boundary layer or in crevices to avoid current, and Psephenus herricki (Dekay) (Coleoptera: Psephenidae) uses suckers to create firm attachments to smooth surfaces. Silk and sticky secretions are produced by Polycentropus chelatus Curtis (Trichoptera: Polycentropidae) and Simulium tuberosum (Lundstrom) (Diptera: Simuliidae) to attach to objects in rapid currents.

The current velocity was higher at Kent Run (Figure 8) at each sample period where there was a significant difference between streams. The relationship between velocity and dissolved oxygen is inter-related. Jaag and Ambuhl (1964) state that it is necessary to discuss both velocity and dissolved oxygen when evaluating a stream and that velocity may be of greater importance than dissolved oxygen. This is because there are a great number of microhabitats in the stream such as snags, leaf packs, macrophytes, etc. where the velocity is lower as well as areas such as runs and riffles where the velocity is higher. In all of these microhabitats the dissolved oxygen may be the same, but there is a wide variation in current velocity. A stream with both an overall higher current velocity and areas of pools, riffles, and runs will have a greater number of invertebrates (Hynes 
1970a). We would expect the higher velocity is also correlated with a greater number of available niches to compete for food gathering, respiration, avoiding competition and predation, and to allow for invertebrates to colonize favorable habitats while avoiding unfavorable ones.

\section{Drought}

While a period of abnormal drought occurred in the summer of 1999, there was continuous year-round water flow in Kent Run and Munnell Hollow in 1998, 2000, and 2001. Drought may result in the cessation of surface flow (Iversen et al. 1978, Kamler and Riedel 1960, and Canton et al. 1984), and often-isolated pools are present as occurred at both Kent Run and Munnell Hollow. Isolated pools are areas of oxygen deficits. The water temperature may reach extreme levels and predator-prey interactions are altered due to the concentration of invertebrates into the diminishing habitat area.

Stream fauna whose normal habitat includes a summer dry phase utilize the following over-summering methods (Williams and Hynes 1977). Some invertebrates have an aerial adult stage during the summer dry period (i.e. Trichoptera, Odonata, Hemiptera, Coleoptera, and Culicidae). Some inhabit permanent waters elsewhere during the dry phase and reinvade the temporary stream (where the entire stream bed dries up) when the water flow resumes in the autumn (i.e. Hemiptera and Coleoptera). Most of the stream invertebrate species that occupy intermittent (only parts of the stream dry up) streams remain in the dry stream channel. Some remain in the isolated pools (i.e. Collembola, Odonata, Hemiptera, Coleoptera, Culicidae and other Diptera), while other species are either shallowly buried in the hyporheic zone (i.e. Ephemeroptera, 
Chironomidae, and Simuliidae eggs) or deeply buried in the hyporheic (i.e. Plecoptera). Some taxa reside under rocks (i.e. Coleoptera adults), some under leaf litter (i.e. Collembola, Hemiptera adults, Trichoptera pupae, Coleoptera adults, and Tipulidae pupae), or as cohabitants in crayfish burrows (i.e. Collembola and Chironomidae). Williams and Hynes (1977) further noted that in a given intermittent stream, there exists a relative stability in species composition of the most abundant taxa from year to year.

Aquatic insects with the following characteristics are not found in temporary or intermittent streams (Clifford 1966). These characteristics include those with life cycles longer than one year, those with more than one generation per year, those with a major period of growth during the summer, and species whose adult emergence occurs in late summer or autumn.

In the watershed areas that contain both Kent Run and Munnell Hollow, there are a number of temporary streams that exhibit surface flow only during the spring of the year and sometimes in the late autumn or early winter. Many streams in both watersheds are also intermittent. Both the temporary and intermittent streams are at slightly higher elevations than either Kent Run or Munnell Hollow.

Several studies have been done on insects in temporary, intermittent, or permanent streams. Although some species may be specific to temporary or intermittent streams, others are facultative, living in temporary, intermittent, and permanent habitats (Knight and Gaufin 1967 and Mackay 1969). Delucchi (1988) showed that although invertebrate community structure may differ among temporary, intermittent, and permanent streams immediately after a period of drying and rewetting, all stream invertebrate communities in a single watershed are similar just before the dry season. Statzner et al. (1988) found 
that the mayfly nymph, Ameletus ludens Needham (Ameletidae), was abundant in temporary, intermittent, and permanent streams. A. ludens was found at both Kent Run (16 individuals) and Munnell Hollow (74 individuals). In the Ryerson study, because of the prevalence of temporary and intermittent streams in both watershed areas, and the fact that all invertebrate communities in a single watershed are similar just before the dry season, it is probable that not many species were missed in sampling or eliminated due to the drought. By utilizing the same mechanisms of those invertebrates that occur in temporary or intermittent streams, these species were able to survive in the normally permanent Kent Run and Munnell Hollow.

\section{River continuum concept}

First and second order streams account for approximately $73 \%$ of the total stream length in the United States (Wallace et al. 1982). The river continuum concept (RCC) perceives running waters as a continuous resource gradient from the headwaters to the sea (Vannote et al. 1980). This concept was initially developed for undisturbed lotic ecosystems in the eastern deciduous forest of North America. According to the RCC, headwater streams (first and second order streams) are heavily canopied, light-limited heterotrophic systems with rocky substrates. They are fed primarily by groundwater and exhibit low-amplitude temperature and flow regimes. The major source of energy is leaf litter that enters the stream from the terrestrial system. According to the RCC, lower order (first and second) streams are heterotrophic and have the lowest gross photosynthesis to community respiration ratio $(\mathrm{P} / \mathrm{R}<1)$. They have the highest CPOM: FPOM 
ratio and the CPOM provides a critical resource base for the consumer

communities in the entire river system. According to the RCC, for first and second order streams the ratio of shredders: collectors: scrapers: predators is $37 \%$ +/- 2\%: 45\%+/- 3\%: 6\% +/- 5\%: 12\%+/- 2\% (Vannote et al. 1980).

\section{Functional feeding groups}

The percentages of the functional feeding groups in the Ryerson study (Figures 10 and 11) differ from those of the River Continuum Concept as follows: Kent Run has $22 \%$ fewer shredders; $18 \%$ more collectors; $1 \%$ more scrapers; and 3\% more predators. Munnell Hollow has 14\% fewer shredders; $15 \%$ fewer collectors; $3 \%$ more scrapers; and $26 \%$ more predators. This difference is partly due to including first through third order streams in the River Continuum Concept and only first order streams in the Ryerson study. In addition, the difference may also be due to the lack of insect habitats for shredders during the drought. Also, it is likely that many more invertebrates occupied the hyporheic zone during the drought than in the streams sampled to develop the River Continuum Concept. The greater percentage of collectors at Kent Run may be due to the larger total area of the stream and consequently more microhabitats for this group. The slightly greater occurrence of scraper taxa at Kent Run and Munnell Hollow may be due to the larger amounts of algae and diatoms on rock surfaces compared to the first order streams studied in the White Clay Creek stream system that formed the basis of the River Continuum Concept (Vannote, personal communication). It should be noted that seasonal and regional differences in River Continuum Concept trends were accounted for 
in a subsequent paper (Minshall 1983b) in which a sliding scale was used to accommodate differences in climate-vegetation-hydrologic settings.

\section{Simpson and Shannon Diversity Indices}

A comparison of adults emerging from the study streams by Simpson and Shannon Diversity Indexes (Table 7) gave different results between the two streams. With the Simpson Index, significant differences occurred at one period each at Kent Run and Munnell Hollow. For the Shannon Diversity Index, of the periods where there was a significant difference between the two streams, higher values occurred at Munnell Hollow.

In scientific studies, there is still widespread use of diversity indices in spite of substantial and continuing criticism of them (Hurlbert 1971, Goodman 1975 and Washington 1984). Different diversity indexes often show different results (Griffith, personal communication), as occurred in the Ryerson study. In addition, diversity indexes are not as reliable as a repeated measures ANOVA for showing both number and relative abundance of species.

\section{Community metrics versus stream}

The community metrics data (Tables 6 and 7) showed a significant difference between streams for the number of collector-filterers, percentage of collector-filterers, number of collector-gatherers, percentage of predators, number of shredder taxa, percentage of shredders, number of scraper taxa, and percentage of scrapers, but not in the number of predator taxa. 
For the immature community metrics data (Table 6), there was a higher number of shredder taxa and a greater percentage of shredders at Munnell Hollow, both a higher number of taxa and a higher percentage of both collector-filterers and collector-gatherers at Kent Run, a higher number of scraper taxa and a greater percentage of scrapers at Kent Run, an equal number of predator taxa at each stream, and a higher percentage of predators at Munnell Hollow.

By being a narrower and steeper stream, Munnell Hollow has more riffle areas than is expected for a conventional stream where a riffle is typically found every 5 to 7 stream widths. With a lower stream velocity than Kent Run, more of the leaf litter and detritus can be retained (Bilby and Likens 1980) and become habitat for shredders (influencing both the number of shredder taxa and the percentage of shredders). Because Kent Run is a wider stream, there are many more habitats for collector-filterers and collectorgatherers in terms of total space (Grant and Mackay 1969), enabling both the number of collector-filterers and collector-gatherers and the percentage of collector-filterers and collector-gatherers to be higher at Kent Run for those periods that had a significant difference between streams. At Kent Run, there were many more areas with moss on the rocks in the stream and also more areas of exposed rocks due to the greater width of the stream. This can account for both the greater number of taxa and percentage of taxa for scrapers at Kent Run.

The community metric results for adults (Table 7) are very similar to those of the immatures. In all of the functional feeding group categories, the ideal situation would be for the immature and adults of each group to agree in the number of periods that are 
significantly different between the streams both in the number of taxa and the percentage of the group. This occurred in the Ryerson study.

\section{Community metrics versus time}

The data set for Kent Run and Munnell Hollow was used to test means of many of the metrics to determine optimal sampling periods for Rapid Bioassessment Protocols (Barbour et al. 1999). The repeated measures ANOVA for week versus time for both each stream separately (Table 9), shows that many metrics are significantly higher for the periods 1 and 26, corresponding with May 12-14, 1999 and April 24-26, 2000, respectively. There is a broad overlap in several metrics such as total number of individuals, percentage of collector-filterers, percentage of collector-gatherers, number of collector-filterers, and number of collector-gatherers where the means were lower than at other times of the year (approximately periods 14 through 22) indicating that these periods would not be recommended for sampling. This information is useful and even necessary if time and/or money are considerations regarding the period of time to sample.

Species availability for collection throughout the year varies according to the life history of the particular invertebrate. During the egg stage, individuals are not available for collection. Examples include various species of Ephemeroptera in spring and early summer: Nixe rusticalis (McDunnough) (Heptageniidae), Leptophlebia nebulosa (Walker) (Leptophlebiidae), and Ameletus ludens (Ameletidae). The same applies to early instars that are too small for the Surber sampler at the mesh used in this study. Pupating holometabolous insects may also be unavailable for collection. Examples of aquatic insect orders with terrestrial pupae in the Ryerson study include Stenelmis lateralis Sand (Coleoptera: Elmidae), Tipula abdominalis (Say) (Diptera: Tipulidae), and 
Nigronia serricornis (Say) (Megaloptera: Corydalidae). In addition, a number of Plecoptera species such as Allocapnia recta (Claassen) and A. maria Hanson undergo diapause in the hyporheic area as early instars and would not be available for collection. Other Plecopterans that diapause include Nemoura trispinosa (Claassen), Amphinemura nigritta (Provancher), A. delosa (Ricker), and Ostracerca truncata (Claassen) (Nemouridae).

The use of repeated measures ANOVA for the analysis of Kent Run and Munnell Hollow indicates the time(s) of the year to sample for each individual metric. This type of data analysis has not previously been done at Ryerson Station State Park. Prior to this study, only species lists of invertebrates have been compiled, and these have not been by time of year when observed. This study has advanced the overall knowledge of both Kent Run and Munnell Hollow not only as to immature and adult species present in these streams, but also as to the time of year to sample for the different community metrics. In the future, perhaps more streams in the park can be analyzed by community metrics. This would both increase the overall general use of community metrics and also their use at Ryerson.

Management implications for the future at Ryerson Station could include some application of the West Virginia Stream Condition Index for Macroinvertebrates (Wirth, personal communication). The EPA developed this index for the West Virginia Division of Environmental Protection, Division of Water Resources. The index is based on six metrics: number of total taxa, number of EPT taxa, percentage of EPT, percentage of the two dominant taxa, and the Hilsenhoff Biotic Index (HBI) to family level (an average tolerance value to organic pollution). Sampling is done from the beginning of May 
through early October, but at no set time as far as metrics are concerned. One sample per stream (mesh size $500 \mu \mathrm{m}$ ) in the riffle-run area of a wadeable stream is taken every 5 years, and on the river areas, up to 5 samples per river per 5 years. The index values run from 0 to 100. Streams are considered not impaired with values above 68 , impaired with values below 60.6 , and a gray area from 60.6 to 68.0 . These values may not represent the best index for the particular stream due to taking only one sample per stream every 5 years. Further, adults are not sampled via emergence traps and this would provide more information regarding impaired versus non-impaired values.

The West Virginia Stream Condition Index for Macroinvertebrates for Kent Run was consistently higher than Munnell Hollow at each sampling period. Overall, for both streams, the indices were higher at sampling periods 1,26 , and 25 . This corresponds with the community metrics versus time data which determined that the best time for sampling these streams was April and the first half of May.

The implications for Ryerson Station include the following. Initially all streams could be sampled once in the first year and assigned an index based on the EPA index for the West Virginia DEP. In subsequent years, the same sampling protocol could be repeated to see how the index scores vary over time. These indices could then be compared with those of other Pennsylvania, West Virginia, and Ohio streams.

The following limitations of the study may have influenced the major findings. The use of a $1000 \mu \mathrm{m}$ mesh instead of a $500 \mu \mathrm{m}$ mesh net reduced the number of early instars collected. Also, the use of Surber samplers in pools is not as reliable as when used in riffles in runs due to the lack of current in pool areas. The riffle and run data should have been used exclusively instead of including it with the pool data. 
In this study of Kent Run and Munnell Hollow over a one-year time period, Kent Run had a greater number of individuals than Munnell Hollow, both for immatures and adults. With its wider area and higher number of leaf packs, snags, and debris dams, there were more habitats for the invertebrate immatures. The lower temperature, higher $\mathrm{pH}$ and hardness, and higher current velocity apparently contributed to these higher numbers. Further, the larger numbers and the higher percentages of collector-filterer and collector-gatherer taxa along with the greater number and percentage of scraper taxa also contributed to the higher numbers of individuals collected.

If this study were to be repeated, there are a number of changes that I would make. Core samples would be taken of the hyporheic zone to find the invertebrates located in this area and at what time of the year they are present. The mesh size of the Surber sampler would be changed from $1000 \mu \mathrm{m}$ to $500 \mu \mathrm{m}$ in order to collect more invertebrates in the smaller larval stages. In addition, mean stream width and mean stream depth would be measured at each sampling period to calculate discharge (mean width $\mathrm{x}$ mean depth $\mathrm{x}$ velocity). 


\section{Literature Cited}

Allan, J. D. 1995. Stream Ecology: Structure and Function of Running Waters. Chapman and Hill, New York.

Anderson, N. H. and J. R. Sedell. 1979. Detritus processing by macroinvertebrates in stream ecosystems. Annual Review of Entomology 24: 351-377.

Barbour, M. T., J. Gerritsen, G. E. Griffith, R. Frydenborg, E. McCarron, J. S. White, and M. L. Bastian. 1996. A framework for biological criteria for Florida streams using benthic macroinvertebrates. Journal of the North American Benthological Society 15: 185-211.

Barbour, M. T., J. Gerritsen, B. D. Snyder, and J. B. Stribling. 1999. Rapid Bioassessment Protocols for Use in Streams and Wadeable Rivers: Periphyton, Benthic Macroinvertebrates, and Fish, Second Edition. EPA 841-B-99-002. U.S. Environmental Protection Agency; Office of Water; Washington, D.C.

Barbour, M. T., J. B. Stribling, and J. R. Karr. 1995. The multimetric approach for establishing biocriteria and measuring biological condition, pp. 69-80. In: W. S. Davis and T. P. Simon (eds.). Biological assessment and criteria: tools for water resource planning and decision-making. Lewis Publishers, New York.

Barnes, J. H. and W. D. Sevon. 1996. Educational Series 4. The Geological Story of Pennsylvania. Pennsylvania Geological Survey, Harrisburg, Pennsylvania.

Benke, A. C. and J. B. Wallace. 1980. Trophic basis of production among netspinning caddisflies in a southern Appalachian stream. Ecology 6: 108-118.

Berrie, A. D. 1976. Detritus, micro-organisms, and animals in fresh water, pp 323-337. In: The Role of Terrestrial and Aquatic Organisms in the decomposition Process(eds. J. M. Anderson and A. Macfadyen). pp. 323337. Blackwell Scientific Publications, Oxford.

Bilby, R. E. and G. E. Likens. 1980. Importance of organic debris dams in the structure and function of stream ecosystem. Ecology 61: 1107-1113.

Boling, R. H., Jr., E. D. Goodman, J. D. Van Sickle, J. O. Zimmer, K. W. Cummins, S. R. Reice, and R. C. Peterson. 1975. Toward a model of detritus processing in a woodland stream. Ecology 56: 141-151. 
Canton, S. P., L. D. Cline, R. A. Short, and J. V. Ward. 1984. The macroinvertebrates and fishes of a Colorado stream during a period of fluctuating discharge. Freshwater Biology 14: 311-316.

Clifford, H. F. 1966. The ecology of invertebrates in an intermittent stream Indiana Lakes and Streams 7: 57-98.

Cochran, W. G. 1953. Sampling Techniques. John Wiley and Sons, New York.

Cole, G. A. 1983. Textbook of Limnology. Mosby, St. Louis.

Corbet, P. S. 1980. Biology of Odonata. Annual Review of Entomology 25: 189217.

Corkum, L. D. and H. F. Clifford. 1980. In: "The importance of species associations and substrate types to behavioural drift", pp. 331-41. In: J. F. Flannigan and K. E. Marshall (eds.). Advances in Ephemeroptera Biology.

Corkum, L. D., P. J. Pointing, and J. J. H. Cibrorowski. 1977. The influence of current velocity and substrate on the distribution and drift of two species of mayflies (Ephemeroptera). Canadian Journal of Zoology 55: 1970-77.

Costello, M. J., T. K. McCarthy, and M. M. O’Farrell. 1984. The stoneflies (Plecoptera) of the Corrib catchment area, Ireland. Annales de Limnologie 20: 25-34.

Cuffney, T. F., J. B. Wallace, and G. J. Lugthart. 1990. Experimental evidence quantifying the role of benthic invertebrates in organic matter dynamics of headwater streams. Freshwater Biology 23: 281-299.

Cummins, K. W. 1962. An evaluation of some techniques for the collection and analysis of benthic samples with special emphasis on lotic waters. America Midland Naturalist 67: 477-504.

Cummins, K. W. 1971. Predicting variations in energy flow through a semi controlled lotic eco-system. Technical Report No. 19, Institute of Water Research, Michigan State University, Lansing.

Cummins, K. W. 1973. Trophic relations of aquatic insects. Annual Review of Entomology 18: 183-206.

Cummins, K. W. 1974. Structure and function of stream ecosystems. Bioscience 24: 631-641.

Cummins, K. W. and M. J. Klug. 1979. Feeding and ecology of stream invertebrates. Annual Review of Ecology and Systematics 11: 147-172. 
Cummins, K. W. and R. W. Merritt. 1996. "Ecology and Distribution of Aquatic Insects" pp. 74-86. In: An Introduction to the Aquatic Insects of North America ( $3^{\text {rd }}$ ed). R. W. Merritt and K. W. Cummins (eds.), Kendall/Hunt Publishing Company, Dubuque, Iowa.

Cummins, K. W. and M. A. Wilzbach. 1985. Field Procedures for the Analysis of Functional Feeding Groups in Stream Ecosystems. Appalachian Environmental Laboratory, Contribution 1611. University of Maryland, Frostburg, Maryland.

Cummins, K. W., M. A. Wilzbach, D. M. Gates, J. B. Perry, and W. B. Taliaferro. 1989. Shredders and riparian vegetation. Bioscience 39: 24-30.

Davis, J. A. and L. A. Barmuta. 1989. An ecologically useful classification of mean and near-bed flows in streams and rivers. Freshwater Biology 21: 271282.

Davis, S. F. and M. J. Winterbourn. 1977. Breakdown and colonization of Nothofagus leaves in a New Zealand stream. Oikos 28: 250-255.

Delucchi, C. M. 1988. Comparison of community structure among streams with different temporal flow regimes. Canadian Journal of Zoology 66: 579-586.

Dufalla, K. 1999. What was, is, and what will be. Greene County Messenger (October 22-28, 1999). Waynesburg, PA.

Eaton, L. E. and D. R. Lenat. 1991. Comparison of a rapid bioassessment method with North Carolina's qualitative macroinvertebrate collection method. Journal of the North American Benthological Society 10: 335-338.

Edington, J. M. 1968. Habitat preferences in net-spinning caddis larvae with special reference to the influence of water velocity. Journal of Animal Ecology 37: 675-692.

Egglishaw, H. J. 1964. The distributional relationship between the bottom fauna and plant detritus in streams. Journal of Animal Ecology 33: 463-476.

Elliott, J. M. 1968. The daily activity patterns of mayfly nymphs (Ephemeroptera). Journal of Zoology 155: 201-222.

Eriksen, C. H. 1968. Ecological significance of respiration and substrate for burrowing Ephemeroptera. Canadian Journal of Zoology 46: 93-103.

Faith, D. P., and R. H. Norris. 1989. Correlation of environmental variables with patterns of distribution and abundance of common and rare freshwater macroinvertebrates. Biological Conservation 50: 77-98. 
Fisher, S. G. and G. E. Likens. 1972. Stream ecosystem: organic energy budget. Bioscience 22: 33-35.

Fisher, S. G. and G. E. Likens. 1973. Energy flow in Bear Brook, New Hampshire: An integrative approach to stream ecosystem metabolism. Ecological Monographs 43: 421- 439.

Fox, H. M., C. A. Wingfield, and B. G. Simmonds. 1937. The oxygen consumption of Ephemerid nymphs from flowing and from still waters in relation to the concentration of oxygen in the water. Journal of Experimental Biology 14: 210-218.

Gibson, G. R. (ed.). 1994. Biological Criteria: Technical Guidance for Streams and Small Rivers. EPA-822-B-94-001. U. S. Environmental Protection Agency, Office of Science and Technology, Washington, D. C.

Goodman, D. 1975. The theory of diversity-stability relationships in ecology. Quarterly Review of Biology 50: 237-266.

Grant, P. R. and R. J. Mackay. 1969. Ecological segregation of systematically related stream insects. Canadian Journal of Zoology 47: 691-694.

Griffith, M. B. 2002. Research Ecologist. Environmental Protection Agency. Cincinnati, Ohio.

Grubaugh, J. W., J. B. Wallace, and E. S. Houston. 1996. Longitudinal changes of macro- invertebrate communities along an Appalachian stream continuum. Canadian Journal of Fisheries and Aquatic Science 53: 896-909.

Hansen, M. H., W. N. Hurwitz, and W. G. Madow. 1953. Sample Survey Methods and Theory. Vol. 1. Methods and Applications. John Wiley and Sons, New York.

Harrison, A. D. and J. D. Agnew. 1962. The distribution of invertebrates endemic to acid streams in the Western and Southern Cape Province. Annuals of the Cape Province Museum 2: 273-291.

Hart, D. D. 1994. Building a stronger partnership between ecological research and biological monitoring. Journal of the North American Biological Society 13: $110-116$.

Hauer, F. R. and G. A. Lamberti. 1996. Methods in Stream Ecology. Academic Press, Inc., New York.

Herbst, G. N. 1979. Detrital leaf dynamics in a lowland forest stream. Ph.D. Thesis. University of Wisconsin, Madison. 
Higler, L. W. G. 1975. Reactions of some caddis larvae (Trichoptera) to different types of substrate in an experimental stream. Freshwater Biology 5: 151-158.

Hildebrand, S. G. 1974. The relation of drift to benthos density and food level in an artificial stream. Limnology and Oceanography 19: 951-957.

Horton, R. E. 1945. Erosional development of streams and their drainage basins; hydrophysical approach to quantitative morphology. Bulletin of the Geological Society of America 56: 275-370.

Hurlbert, S. H. 1971. The nonconcept of species diversity: a critique and alternative parameters. Ecology 52: 577-586.

Hynes, H. B. N. 1970a. The Ecology of Running Waters. Univ. Toronto Press, Toronto.

Hynes, H. B. N. 1970b. The ecology of stream insects. Annual Review of Entomology 15: 135-153.

Hynes, H. B. N., N. K. Kaushik, M. A. Zock, D. L. Lush, Z. S. J. Stocker, R. R. Wallace, and D. D. Williams. 1974. Benthos and allochthonous organic matter in streams. Journal of the Fisheries Research Board of Canada 31: 545-553.

Iversen, T. M. 1973. Decomposition of autumn-shed beech leaves in a springbrook and its significance for the fauna. Archiv fuer Hydrobiologie 72: 305312.

Iversen, T. M. and B. L. Madsen. 1977. Allochthonous organic matter in streams. Felia Limnologia of Scandanavia 17: 17-20.

Iversen, T. M., J. Thorp, and J. Skriver. 1982. Inputs and transformations of allochthonous particulate organic matter in a headwater stream. Holarctic Ecology 5: 10-19.

Iversen, T. M., P. Wiberg-Larsen, S. B. Hansen, and F. S. Hansen. 1978. The effect of partial and total drought on the macroinvertebrate communities of three small Danish streams. Hydrobiologa 60: 235-242.

Jaag, O. and H. Ambuhl. 1964. The effect of current on the composition o biocoenoses in flowing water streams. Advances in Water Pollution Research 1: 31-49.

Kamler, E. and W. Riedel. 1960. The effect of drought on the Ephemeroptera, Plecoptera and Trichoptera of a mountain stream. Polis Archives of Hydrobiology 8: 87-94. 
Kaushik, N. K. and H. B. N. Hynes. 1968. Experimental study on the role of autumn-shed leaves in aquatic environments. Journal of Ecology 56: 229-243.

Kaushik, N. K. and H. B. N. Hynes. 1971. The fate of dead leaves that fall into streams. Archiv fuer Hydrobiologie 68: 465-515.

Knight, A. W. and A. R. Gaufin. 1963. The effect of water flow, temperature, and oxygen concentration on the Plecoptera nymph, Acroneuria pacifica Banks. Proceedings of the Utah Academy of Sciences, Arts, and Letters 40: 175-184.

Knight, A. W. and A. R. Gaufin. 1964. Relative importance of varying oxygen concentration, temperature, and water flow on the mechanical activity and survival of the Plecoptera nymph, Pteronarcys californica Newport. Proceedings of the Utah Academy of Sciences, Arts, and Letters 41: 14-28.

Knight, A. W. and A. R. Gaufin. 1966. Oxygen consumption of several species of stoneflies (Plecoptera). Journal of Insect Physiology 12: 347-355.

Knight, A. W. and A. R. Gaufin. 1967. Stream type selection and associations of stoneflies (Plecoptera) and Colorado river drainage system. Journal of the Kansas Entomological Society 40: 347-352.

Kovalak, W. P. 1976. Seasonal and diel changes in the positioning of Glossosoma nigrior Banks (Trichoptera: Glossosomatidae) on artificial substrates. Canadian Journal of Zoology 54: 1585-1594.

Ladle, M. and J. A. B. Bass. 1981. The ecology of a small chalk stream and its response to drying during drought conditions. Archiv fuer Hydrobiologie 90: 448-466.

Larimore, R. W., W. F. Childers, and C. Heckrotte. 1959. Destruction and re-establishment of stream fish and invertebrates affected by Transactions of the American Fisheries Society 88: 261-285.

Leopold, L. B., M. G. Wolman, and J. D. Miller. 1964. Fluvial Processes in Geomorphology. Freeman, San Francisco.

Linduska, J. P. 1942. Bottom type as a factor influencing the local distribution of mayfly nymphs. The Canadian Entomologist 74: 26-30.

Macan, T. T. 1961a. A review of running water studies. Verhandelingen der Internationale Limnologie 14: 578-602.

Macan, T. T. 1961b. Factors that limit the range of freshwater animals. Biologica Review 36: 151-198. 
Macan, T. T. 1974. Freshwater Ecology, $2^{\text {nd }}$ ed. Wiley, New York.

Mackay, R. J. 1969. Aquatic insect communities of a small stream on Mont St. Hilaire, Quebec. Journal of the Fisheries Research Board of Canada 26: 11571183.

Mackay, R. J. and J. Kalff. 1969. Seasonal variation in standing crop and species diversity of insect communities in a small Quebec stream. Ecology 50: 101109.

Merritt, R. W. and K. W. Cummins. 1996. An Introduction to the Aquatic Insects North America ( $3^{\text {rd }}$ ed.). Kendall/Hunt Publishing Company, Dubuque, Iowa.

Merritt, R. W., K. W. Cummins, and T. M. Burton. 1984. "The Role of Aquatic Insects in the Processing and Cycling of Nutrients", pp. 134-163. In: V. H Resh and D. M.Rosenberg (eds.). The Ecology of Aquatic Insects. Praeger Publishers, New York.

Meyer, J. L. and J. O'Hop. 1983. Leaf shredding insects as a source of dissolved organic carbon in head-water streams. American Midland Naturalist 109: 175183.

Minshall, G. W. 1968. Community dynamics of the benthic fauna in a woodland springbrook. Hydrobiologia 32: 305-309.

Minshall, G. W. 1978. Autotrophy in stream ecosystems. Bioscience 28: 767-771.

Minshall, G. W. 1984. “Aquatic Insect-Substratum Relationships”, pp. 358-400. In: V. H. Resh and D. M. Rosenberg (eds.). The Ecology of Aquatic Insects. Praeger Publishers, New York.

Minshall, G. W., D. A. Andrews, C. Y. Manuel-Faler. 1983a. Application of island biogeography theory to streams: macroinvertebrate recolonization of the Teton River, Idaho, pp. 279-297. In: J. R. Barnes and G. W. Minshall (eds). Stream Ecology: Application and Testing of Ecological Theory. Plenum Press, New York.

Minshall, G W., R. C. Petersen, K. W. Cummins, T. L. Bott, J. R. Sedell, C. E. Cushing, and R. L. Vannote. 1983b. Interbiome comparison of stream ecosystem dynamics. Ecological Monographs 53: 1-25.

Minshall, G. W. and P. V. Winger. 1968. The effect of reduction in stream flow on invertebrate drift. Ecology 49: 580-582. 
Moeller, J. R., G. W. Minshall, K. W. Cummins, R. C. Peterson, C. E. Cushing, J. R. Sedell, R. Larson, and R. L. Vannote. 1979. Transport of dissolved organ carbon in streams of differing physiographic characteristics. Organic Geochemistry 1: 139-150.

Neel, J. K. 1973. Biotic character as related to stream mineral content. Transactions of the American Microscopial Society 92: 404-415.

Peckarsky, B. L. 1980a. Influence of detritus upon colonization of stream invertebrates. Canadian Journal of Fisheries and Aquatic Science 37: 957-963.

Peckarsky, B. L. 1980b. Predator-prey interactions between stoneflies and mayflies: behavioral observations. Ecology 61: 932-943.

Peterson, R. C. and K. W. Cummins. 1974. Leaf processing in a woodland stream. Freshwater Biology 4: 333-368.

Philipson, G. N. 1954. The effect of waterflow and oxygen concentration on six species of caddisfly (Trichoptera). Proceedings of the Zoological Society of London 124: 547-564.

Rabeni, C. F. and G. W. Minshall. 1977. Factors affecting microdistribution of stream benthic insects. Oikos 29: 33-43.

Reice, S. R. 1974. Environmental patchiness and the breakdown of leaf litter in a woodland stream. Ecology 55: 1271-1282.

Reice, S. R. 1977. The role of animal association and current velocity in sediment-specific leaf litter decomposition. Oikos 29: 357-365.

Resh, V. H. and J. K. Jackson. 1993. Rapid Bioassessment approaches to biomonitoring using benthic macroinvertebrates, pp. 195-233. In: D. M. Rosenberg and V. H. Resh (eds.). Freshwater biomonitoring and benthic macroinvertebrates, Chapman and Hall, New York.

SAS: 1996, SAS/STAT Users Guide, SAS Institute, Cary, NC.

Scott, D. 1958. Ecological studies on the Trichoptera of the River Dean. Chesire Archiv Fuer Hydrobiologie 54: 340-392.

Shaw, D. W. and G. W. Minshall. 1980. Colonization of an introduced substrate by stream macro-invertebrates. Oikos 34: 259-271.

Short, R. A. and P. E. Maslin. 1977. Processing of leaf litter by a stream detritivore: effect on nutritional availability to collectors Ecology 58: 935-938. 
Stanford, J. A. and J. V. Ward. 1988. The hyporheic habitat of river ecosystems. Nature 335: 64-66.

Stanford, J. A. and J. V. Ward. 1993. An ecosystem perspective of alluvial rivers: connectivity and the hyporheic corridor. Journal of the North American Benthological Society 12: 48-60.

Statzner, B., J. A. Gore, and V. H. Resh. 1988. Hydraulic stream ecology: Observed patterns and potential applications. Journal of the North American Benthological Society 7: 307-360.

Stern, M. S. and D. S. Stern. 1969. A limnological study of a Tennessee cold springbrook. American Midland Naturalist 82: 62-82.

Strahler, A. N. 1957. Quantitative analysis of watershed geomorphology. Transactions of the American Geophysical Union 38: 913-920.

Sweeney, B. W. and R. L. Vannote. 1981. Ephemerella mayflies of White Clay Creek: bioenergetic and ecological relationships among six coexisting species. Ecology 62:1353-1369.

Thorp, J. H. and A. P. Covich. 1991. Ecology and Classification of North American Freshwater Invertebrates. Academic Press, Inc. San Diego California.

Townsend, C. R. 1980. The Ecology of Streams and Rivers. The Institute of Biology, Studies in Biology. No. 122. Camelot Press, Ltd., Southampton, Great Britain.

Townsend, C. R. and A. G. Hildrew. 1976. Field experiments on the drifting, colonization, and continuous redistribution of stream benthos. Journal of Animal Ecology 45: 759-772.

Triska, F. J., J. R. Sedell, and B. Buckley. 1975. The processing of conifer and hardwood leaves in two coniferous forest streams. II. Biochemical and nutrient changes. Verhandlungen der Internationalen Vereinigung fuer Theoretische und Angewandte Limnologie 19: 1628-1640.

Ulfstrand, S. 1967. Microdistribution of benthic species (Ephemeroptera, Plecoptera, Trichoptera, Diptera: Simuliidae) in Lapland streams. Oikos 18: 293-310.

Uresk, D. W. 1967. The substrate preference of aquatic insects in Trout Creek, Wasatch County, Utah. M. S. Thesis, University of Utah, Salt Lake City, Utah. 
Vannote, R. L. 1981. The river continuum: a theoretical construct for analysis of river ecosystems, pp. 289-304. In: R. Cross (ed.). Proceedings of the National Symposium on Fresh-water Inflow to Estuaries. Vol. 2. U. S. Fish and Wildlife Service, Washington, D. C.

Vannote, R. L., G. W. Minshall, K. W. Cummins, J. R. Sedell, and C. E. Cushing. 1980. The river continuum concept. Canadian Journal of Fisheries and Aquatic Science 37:130-137.

Vannote, R. L. and B. W. Sweeney. 1980. Geographic analysis of thermal equilibria: a conceptual model for evaluating the effect of natural and modified thermal regimes on aquatic insect communities. The American Naturalist 115: 667-695.

Wallace, J. B. and R. W. Merritt. 1980. Filter-feeding ecology of aquatic insects. Annual Review of Entomology 25: 103-132.

Wallace, J. B., J. R. Webster, and T. F. Cuffney. 1982. Stream detritus dynamics: Regulation by invertebrate consumers. Oecologia 53: 197-200

Wallace, J. B., J. R. Webster, and W. R. Woodall. 1977. The role of filter feeders in flowing waters. Archiv fur Hydrobiologie 79: 506-532.

Ward, J. V. 1992. Aquatic Insect Ecology 1. Biology and Habitat. John Wiley and Sons, Inc., New York.

Ward, J. V. and B. C. Kondratieff. 1992. An Illustrated Guide to the Mountain Stream Insects of Colorado. Univ. Press of Colorado. Niwot, Colorado.

Washington, H. G. 1984. Diversity, biotic and similarity indices. A review with special relevance to aquatic ecosystems. Water Research 18: 653-694.

Webster, J. R. 1983. The role of benthic macroinvertebrates in detritus dynamics of streams: a computer simulation. Ecological Monographs 53: 383-403.

Webster, J. R. and B. C. Patten. 1979. Analysis of potassium and calcium dynamics in stream ecosystems on three southern Appalachian watersheds of contrasting vegetation. Ecological Monographs 49: 51-72.

Wetmore, S. H., R. J. MacKay, and R. W. Newbury. 1990. Characterization of the hydraulic habitat of Brachycentrus occidentalis, a filter-feeding caddisfly. Journal of the North American Benthological Society 9: 157-169.

Wiley, M. J. and S. L. Kohler. 1981. An assessment of biological interactions in an epilithic stream community using time-lapse cinematography. Hydrobiologia 78:183-188. 
Williams, D. D. and B. W. Feltmate. 1992. Aquatic Insects. CAB International, UK.

Williams, D. D. and H. B. N. Hynes. 1977. The ecology of temporary streams. II. General remarks on temporary streams. Internationale Revue der Gesamten Hydrobiologie 62: 53-61.

Wingfield, C. A. 1939. The function of the gills of mayfly nymphs from different habitats. Journal of Experimental Biology 16: 363-373.

Wirth, J. 2002. Program Manager, Watershed Assessment Section, DEP, Division of Water Resources. Charleston, West Virginia.

Yang, C. T. 1971. Formation of riffles and pools. Water Resources Research 7: 1567-1574. 


\section{Appendix 1}

\section{Keys used in identification of adult and immature aquatic insects}

\section{General:}

Borror, Donald J., Dwight M. DeLong, and Charles A. Triplehorn. 1976. An Introduction to the Study of Insects. Holt, Rinehart, and Winston, New York. 852 pp.

Hilsenhoff, William L. Technical Bulletin 89. Dept. of Natural Resources. Madison, Wisconsin. 1975. Aquatic Insects of Wisconsin. With Generic Keys and Notes on Biology, Ecology, and Distribution. 53 pp.

McCafferty, W. Patrick. 1998. Aquatic Entomology. Jones and Bartlett Publishers, Inc., Sudbury, Massachusetts. 448 pp.

Merritt, Richard W. and Kenneth W. Cummins. 1996. An Introduction to the Aquatic Insects of North America. Kendall/Hunt Publishing Company; Dubuque, Iowa. 862 pp.

Peckarsky, Barbara L., Pierre R. Fraissinet, Marjory A. Penton, and Don J. Conklin, Jr. 1990. Freshwater Macroinvertebrates of Northeastern North America. Cornell University Press, Ithaca. 442 pp.

Pennak, Robert W. 1953. Fresh-Water Invertebrates of the United States. The Ronald Press Company, New York. 769 pp.

Peterson, Alvah. 1960. Larvae of Insects. Part II: Coleoptera, Diptera, Neuroptera, Siphonaptera, Mecoptera, Trichoptera. Edwards Brothers, Inc., Ann Arbor, Michigan. $416 \mathrm{pp}$.

Peterson, Alvah. 1962. Larvae of Insects. Part I: Lepidoptera and Plant Infesting Hymenoptera. Edwards Brothers, Inc., Ann Arbor, Michigan. 315 pp.

Usinger, Robert L. (ed.) 1956. Aquatic Insects of California. University of California Press, Berkeley. 508 pp.

Ward, J. V. and B. C. Kondratieff. 1992. An Illustrated Guide to the Mountain Stream Insects of Colorado. University Press of Colorado, Niwot, Colorado. 191 pp.

\section{Collembola:}

Waltz, R. D. and W. P. McCafferty. February, 1979. Freshwater Springtails (Hexapoda:Collembola) of North America. Purdue University Agricultural Experiment Station, West Lafayette, Indiana. Research Bulletin 960. 


\section{Ephemeroptera:}

Burks, B. D. 1953. The Mayflies, or Ephemeroptera, of Illinois. Illinois Natural History Survey Division, Urbana. Vol. 26: 1-216.

Edmunds, George F., Steven L. Jensen, and Lewis Berner. 1976. The Mayflies of North and Central America. University of Minnesota Press, Minneapolis. 330 pp.

\section{Odonata:}

Johnson, Clifford. 1972. The Damselflies (Zygoptera) of TEXAS. Bulletin of the Florida State Museum Biological Sciences. Volume 16, Number 2. 128 pp.

Needham, James G. and Minter J. Westfall, Jr. 1955. A Manual of the Dragonflies of North America (Anisoptera) including the Greater Antilles and the Provinces of the Mexican Border. University of California Press, Los Angeles. 615 pp.

Walker, Edmund M. 1953. The Odonata of Canada and Alaska. Volume 1. Part I: General; Part II: The Zygoptera-Damselflies. University of Toronto Press, Toronto. 292 pp.

Walker, Edmund M. 1958. The Odonata of Canada and Alaska. Volume 2. Part III: The Anisoptera. Four Families (Aeshnidae, Petaluridae, Gomphidae, and Cordulegasteridae). University of Toronto Press, Toronto. 318 pp.

Walker, Edmund M. and Philip S. Corbet. 1975. The Odonata of Canada and Alaska. Volume 3. Part III: The Anisoptera. Three Families (Macromiidae, Corduliidae, and Libellulidae). University of Toronto Press, Toronto. 308 pp.

\section{Plecoptera:}

Baumann, Richard W., Arden R. Gaufin, and Rebecca F. Surdick. 1977. The Stoneflies (Plecoptera) of the Rocky Mountains. Memoirs of the American Entomological Society \#31. American Entomological Society at the Academy of Natural Sciences. Philadelphia. 208 pp.

Claasen, Peter W. 1931. Plecoptera Nymphs of America (North of Mexico). Charles C. Thomas, Springfield, Illinois. $195 \mathrm{pp}$.

Hitchcock, Stephen W. 1974. Guide to the Insects of Connecticut. Part VII. The Plecoptera or Stoneflies of Connecticut. Bulletin Number 107. State Geological and Natural History Survey of Connecticut. $262 \mathrm{pp}$. 
Poulton, Barry C. and Kenneth W. Stewart. 1991. The Stoneflies of the Ozark and Ouachita Mountains (Plecoptera). Memoirs of the American Entomological Society Number 38. American Entomological Society at the Academy of Natural Sciences, Philadelphia. $116 \mathrm{pp}$.

Ricker, William E. 1952. Systematic Studies in Plecoptera. Indiana University Publications Science Series (18). 200 pp.

Ross, Herbert H. and William E. Ricker. 1971. The Classification, Evolution, and Dispersal of the Winter Stonefly Genus Allocapnia. Illinois Biological Monographs 45. University of Illinois Press, Urbana. 166 pp.

Stark, Bill P. and Arden R. Gaufin. 1974. The Species of Calineuria and Dorneuria (Plecoptera: Perlidae). Great Basin Naturalist 34(2): 83-93.

Stark, Bill P. and Arden R. Gaufin. 1976. The Nearctic Genera of Perlidae (Plecoptera). Miscellaneous Publications of the Entomological Society of America 10(1): 1-77.

Stewart, Kenneth W. and Bill P. Stark. 1993. Nymphs of North American Stonefly Genera (Plecoptera). University of North Texas Press, Denton, Texas. 460 pp.

Surdick, Rebecca F. 1985. Nearctic Genera of Chloroperlinae (Plecoptera: Chloroperlidae). Illinois Biological Monographs 54. University of Illinois Press. 146 pp.

Surdick, Rebecca F. and Ke Chung Kim. 1976. Stoneflies (Plecoptera) of Pennsylvania. A Synopsis. Bulletin 808, May 1976. The Pennsylvania State University; College of Agriculture; Agricultural Experiment Station; University Park, Pennsylvania. 73 pp.

\section{Hemiptera:}

Bobb, Marvin L. 1974. The Insects of Virginia: No. 7. The Aquatic and SemiAquatic Hemiptera of Virginia. Research Division Bulletin 87. Virginia Polytechnic Institute and State Univesity. Blacksburg, VA. 196 pp.

Polyhemus, Dan A. 1977. Systematics of the Genus Rhagovelia Mayr (Heteroptera: Veliidae) in the Western Hemisphere (Exclusive of the angustipes Complex). Entomological Society of America, Lanham, Maryland. $386 \mathrm{pp}$. 


\section{Megaloptera and Neuroptera:}

Contreras-Ramos, Atilano. 1998. Systematics of the Dobsonfly Genus Corydalus (Megaloptera: Corydalidae). Entomological Society of America, Lanham, Maryland. $360 \mathrm{pp}$.

Hazard, Edwin Irwin. 1960. A Revision of the Genera Chauliodes and Nigronia (Megaloptera:Corydalidae). Ohio State University M. S. Thesis. 89 pp.

\section{Coleoptera:}

Arnett, Ross H. 1963. The Beetles of the United States. The Catholic University of America Press, Washington, D. C. 1112 pp.

\section{Diptera:}

Amrine, James W., Jr. 1971. The Black Flies (Diptera: Simuliidae) of Ohio. The Ohio State University. M. S. Thesis. 278 pp.

Johannsen, O. A. 1969. Aquatic Diptera. Entomological Reprint Specialists, Los Angeles, California. 80 pp.

Manual of Nearctic Diptera, Volume 1. Sponsored by Agriculture Canada. 1981. 674 pp.

Manual of Nearctic Diptera, Volume 2. Sponsored by Agricultured Canada. 1987. $662 \mathrm{pp}$.

Peterson, B. V. 1970. The Prosimulium of Canada and Alaska (Diptera: Simuliidae). The Entomological Society of Canada, Ottawa. 216 pp.

Stone, Alan. 1964. Guide to the Insects of Connecticut. Part VI. The Diptera or True Flies of Connecticut, Simuliidae and Thaumaleidae. Bulletin Number 97. State Geological and Natural History Survey of Connecticut. 126 pp.

Stone, Alan and E. L. Snoddy. 1969. The Black Flies of Alabama (Diptera: Simuliidae). Agricultural Experiment Station. Auburn University. 93 pp.

\section{Trichoptera:}

Anderson, N. H. 1976. The Distribution and Biology of the Oregon Trichoptera. Technical Bulletin 134. Agricultural Experiment Station. 152 pp. 
Armitage, Brian J. 1996. Diagnostic Atlas of the North American Caddisfly Adults I. Philopotamidae. The Caddis Press. 92 pp.

Armitage, Brian J. and Steven N. Hamilton. 1990. Diagnostic Atlas of the North American Caddisfly Adults. II. Ecnomidae, Polycentropidae, Psychomyiidae, and Xiphocentronidae. The Caddis Press. 150 pp.

Flint, Oliver Simeon, Jr. 1960. Taxonomy and biology of some Nearctic Limnephilid larvae (Trichoptera) with special reference to species in eastern United States. Ph.D. Thesis. Cornell University. $231 \mathrm{pp}$.

Parker, C. R. and G. B. Wiggins. 1987. Revision of the Caddisfly Genus Psilotreta (Trichoptera:Odontoceridae). Royal Ontario Museum Life Sciences Contribution 144. 55 pp.

Ross, Herbert H. 1974. The Caddis Flies, or Trichoptera, of Illinois. Entomological Reprint Specialists, Los Angeles, California. 326 pp.

Scheffer, Patricia W. and Glenn B. Wiggins. 1986. A Systematic Study of the Nearctic Larvae of the Hydropsyche morosa Group (Trichoptera: Hydropsychidae). Life Sciences Miscellaneous Publications, Royal Ontario Museum. 94 pp.

Wiggins, Glenn B. 1996. Larvae of the North American Caddisfly Genera (Trichoptera). University of Toronto Press, Toronto. $457 \mathrm{pp}$. Zoology; Carnegie Museum of Natural History; 4400 Forbes Avenue; Pittsburgh, PA 15213. 


\section{Appendix 2. Invertebrates collected at Kent Run and Munnell Hollow from}

\section{May 1999 to 25 April 2000.}

KR

MH

Phylum Arthropoda - Class Crustacea

Isopoda

Asellus militaris Hay

X

$\mathrm{X}$

Phylum Arthropoda - Class Insecta

Entomobryidae

Seira sp. MacGillivray

Salina banksi MacGillivray

$\mathrm{X}$

$\mathrm{X}$

Odonata

Coenagrionidae

Chromagrion conditum (Hagen)

$\mathrm{X}$

Cordulegasteridae

Cordulegaster obliquus (Say)

Cordulegaster sayi Selys

Cordulegaster maculatus Selys

Note: Cordulegaster $=$ Taeniogaster

Aeschnidae Epiaesehna heros (Fabricius)

Boyeria vinosa (Say)

Gomphidae

Lanthus parvulus (Selys)

Lanthus albistylus (Hagen)

Calopterygidae

Calopteryx maculata Leach

Calopteryx maculatum Beauvois
$\mathrm{X}$

$\mathrm{X}$

$\mathrm{X}$

$\mathrm{X}$

$\mathrm{X}$

$\mathrm{X}$

$\mathrm{X} \quad \mathrm{X}$

$\mathrm{X}$

$\mathrm{X}$

$\mathrm{X}$

$($ Calopterygidae $=$ Agrionidae and Calopteryx $=$ Agrion $)$

Ephemeroptera

Isonychiidae

Isonychia sp. Eaton

X

(Oligonouridae) 
Ephemerellidae

Heptageniidae

Ameletidae

(Merritt/Cummins

formerly

Siphlonuridae

Leptophlebiidae
Serratella sp. Edmunds

Eurylophella sp. (McDunnough)

Ephemerella sp. Walsh

Epeorus pleurialis (Banks)

Epeorus vitrea (Walker)

Stenonema meririvulanum

Carle and Lewis

Stenonema sp. Traver

Epeorus sp. Eaton

Nixe rusticalis (McDunnough)

Stenacron sp. Jensen

Cinygmula sp. McDunnough

Stenonema femoratum (Say)

Stenacron carolina (Banks)

Epeorus vitrea (subgenus Iron)

Eaton

Ameletus lineatus Traver

Ameletus ludens Needham

$\begin{array}{cc}X & X \\ X & X \\ X & X\end{array}$

$\begin{array}{ll}X & X\end{array}$

X $\quad X$

X $\quad X$

$\begin{array}{ll}X & X\end{array}$

$X \quad X$

$X \quad X$

$\mathrm{X} \quad \mathrm{X}$

X $\quad X$

$\mathrm{X}$

X

$\mathrm{X}$

X $\quad X$

X $\quad \mathrm{X}$

(McDunnough)

Paraleptophlebia debilis (Walker)

Leptophlebia nebulosa (Walker)

Leptophlebia cupida (Say)

Paraleptophlebia activa

(McDunnough)

Baetis flavistriga McDunnough

Acentrella turbida Bengtsson

$\mathrm{X}$

$\mathrm{X}$

X X

$X \quad X$

X $\quad X$

$\mathrm{X}$

Ephemera guttulata Pictet

Ephemera simulans Walker $\begin{array}{ll} & X \\ X & X\end{array}$

$\mathrm{X}$

X $\quad$ X 
Alloperla banksi Frison

Haploperla brevis (Banks)

Suwallia marginata (Banks)

Alloperla sp. Banks

$\begin{array}{cc}X & X \\ X & X \\ X & X\end{array}$

Nemouridae

Nemoura trispinosa Claassen

$\mathrm{X}$

Amphinemura nigritta

(Provancher)

Amphinemura delosa (Ricker)

Ostracerca truncata (Claassen)

X

$\mathrm{X}$

$\mathrm{X}$

Peltoperlidae

Peltoperla arcuata Needham

X $\quad X$

Perlodidae

Isoperla similis (Hagen)

Diploperla duplicata (Banks)

Cultus decisus (Walker)

Isoperla sp. Banks

Isoperla clio (Newman)

Isoperla richardsoni Frison

Clioperla clio (Newman)

Yugus bulbosus (Frison)

Yugus arinus (Frison)

Diura sp. Billberg

Remenus bilobatus

$\mathrm{X}$

X $\quad X$

X $\quad X$

$\mathrm{X}$

(Needham and Claassen)

Isoperla bilinenta (Say)

Isogenoides hansoni Ricker

$X \quad X$

$\mathrm{X} \quad \mathrm{X}$

$\mathrm{X}$

$X \quad X$

$X$

$\mathrm{X}$

$X \quad X$

$\begin{array}{ll}X & X\end{array}$

$X \quad X$

$\mathrm{X}$

$\begin{array}{ll} & X \\ X & X\end{array}$

Perlidae

Acroneuria lycorias (Newman)

Acroneuria internata Walker)

Acroneuria carolinensis (Banks)

Acroneuria abnormis (Newman)

Acroneuria sp. Pictet

X $\quad X$

$\mathrm{X}$

$\mathrm{X} \quad \mathrm{X}$

Agnetina annulipes (Hagen) X

Capniidae

Allocapnia recta (Claassen)

$\mathrm{X}$

X

Allocapnia maria Hanson

$\mathrm{X}$

Leuctra sibleyi Claassen

Leuctra sp. Stephens

Leuctra ferruginea (Walker)

Paraleuctra sara (Claassen)

$\begin{array}{cc} & X \\ X & X \\ X & X \\ X & \\ X & X\end{array}$

Leuctra tenuis (Pictet)

X 
Hemiptera

Gerridae

Veliidae

Psephenidae

Elmidae

Chrysomelidae

Hydrophilidae

Carabidae

Megaloptera

Corydalidae

Sialidae

Neuroptera

Chrysopidae

Mecoptera

Panorpidae

Bittacidae
Gerris caniculatus Say

Gerris remigis Say

Gerris conformis (Uhler)

Gerris insperatus

Drake and Hottes

$\begin{array}{ll}X & X \\ X & X \\ X & \\ X & X\end{array}$

$\mathrm{X}$ Microvelia borealis Bueno Microvelia americana (Uhler)

$\mathrm{X}$

$\mathrm{X}$
X $\quad$ X

X

X $\quad X$

X

$\mathrm{X}$

Pterostichus diligendus Chaudoir

X $\quad X$

Corydalus cornutus (L.)

Sialis sp. Latreille

X

X $\quad X$

Chrysopa sp.

$x$


Trichoptera

\begin{tabular}{|c|c|c|}
\hline Goeridae & $\begin{array}{l}\text { Goera sp. Banks } \\
\text { Goera stylata Curtis }\end{array}$ & $\begin{array}{l}X \\
X\end{array}$ \\
\hline Lepidostomatidae & $\begin{array}{l}\text { Lepidostoma sp. Rambur } \\
\text { Lepidostoma liba Ross }\end{array}$ & $\mathrm{X}$ \\
\hline $\begin{array}{l}\text { Polycentropodidae } \\
\text { (Psychomyiidae } \\
\text { not used) }\end{array}$ & $\begin{array}{l}\text { Polycentropus chelatus Curtis } \\
\text { Polycentropus centralis Banks } \\
\text { Polycentropus sp. Curtis } \\
\text { Polycentropus remotus Banks }\end{array}$ & $\begin{array}{l}X \\
X \\
X\end{array}$ \\
\hline $\begin{array}{l}\text { Limnephilidae } \\
\text { (Previously } \\
\text { Astenophylax) }\end{array}$ & $\begin{array}{l}\text { Pycnopsyche luculenta (Betten) } \\
\text { Hydatophylax argus (Harris) } \\
\text { Pycnopsyche gentilis McLachlan } \\
\text { Platycentropus sp Ulmer } \\
\text { Ironoquia punctatissima(Walker) } \\
\text { Chyranda centralis (Banks) }\end{array}$ & $\begin{array}{l}X \\
X \\
X \\
X \\
X\end{array}$ \\
\hline Hydroptilidae & $\begin{array}{l}\text { Hydroptila sp. Dalman } \\
\text { Agraylea multipunetata Curtis } \\
\text { Hydroptila hamata Morton }\end{array}$ & $\begin{array}{l}X \\
X \\
X\end{array}$ \\
\hline Philopotamidae & $\begin{array}{l}\text { Wormaldia (=Dolophilus) moesta } \\
\text { (Banks) } \\
\text { Dolophilus shawnee Ross } \\
\text { Chimarra aterrima Hagen }\end{array}$ & $\mathrm{X}$ \\
\hline Rhyacophilidae & $\begin{array}{l}\text { Rhyacophila fuscula (Walker) } \\
\text { Rhyacophila vibrox Milne } \\
\text { Rhyacophila fenestra Ross }\end{array}$ & $\begin{array}{l}X \\
X \\
X\end{array}$ \\
\hline Helicopsychidae & Helicopsyche borealis Hagen & $\mathrm{X}$ \\
\hline Glossosomatidae & $\begin{array}{l}\text { Agapetus illini Ross } \\
\text { Glossosoma nigrior Banks }\end{array}$ & $\mathrm{X}$ \\
\hline Molannidae & $\begin{array}{l}\text { Molanna blenda Sibley } \\
\text { Molanna uniophila Vohries }\end{array}$ & \\
\hline
\end{tabular}


Hydropsychidae

Uenoidae

Brachycentridae

Odontoceridae

Lepidoptera

Pyralidae

Psocoptera

Psocoptera

Diptera

Empididae

Simuliidae

Syrphidae

Sciaridae

Phoridae

Ephydridae
Diplectrona modesta Banks

Cheumatopsyche pettiti (Banks)

Hydropsyche sp. Pictet

Potamyia flava (Hagen)

Parapsyche apicalis (Banks)

Cheumatopsyche sp. Wallengren

Neophylax consimilis (Betten)

Neophylax autumnus Vorhies

Micrasema rusticum (Hagen)

Psilotreta indecisa (Walker)
$\mathrm{X} \quad \mathrm{X}$

$\mathrm{X}$

$X \quad X$

$X \quad X$

$\begin{array}{ll}\mathrm{X} \\ \mathrm{X} & \mathrm{X}\end{array}$

X $\quad X$

$\mathrm{X}$

$\mathrm{X}$

X

X

$\begin{array}{ll}X & X \\ X & X\end{array}$

Paragyractis sp. Lederer

Synclita sp. Lederer
Rhamphoyia sp. Meigen X X

Simulium tuberosum (Lundstrom) X

Cnephia (Stegopterna) mutata

(Malloch)

Prosimulium rhizophorum X X

Stone and Jamnback

Prosimulium (Prosimulium) magnum $\quad$ X $\quad$ X

Dyar and Shannon

Melangyna sp

Lytogaster_sp Becker
$\mathrm{X}$

$\mathrm{X}$ X X

X X

$\mathrm{X}$

$X$

X X 
Cecidomyiidae

Ceratopogonidae

Agromyzidae

Heliomyzidae

Tipulidae
Atrichopogon sp Kieffer

X

$\mathrm{X}$

$\mathrm{X}$

$\mathrm{X}$

$\mathrm{X}$

Hexatoma sp. Latreille

Tipula (Yamatotipula) noveboracensis

Alexander

Limonia fusca Meigen

Tipula (Nippotipula) abdominalis (Say)

Clunatipula mallochi Alexander

Epiphragma (Epiphragma) fasciapennis (Say)

Limnophila (Lasiomastix) subtervicornis $\quad \mathrm{X}$ (Alexander)

Pseudolimnophila (P.) contempta

(Osten Sacken)

Tipula (lunatipula) mallochi Alexander

Eriocera spinosa (Osten Sacken)

Dolichopeza (oropeza) carolus Alexander

Dolichopeza (oropeza) walleyi

(Alexander)

Tipula (Triplicitipula) valida Loew

Hexatoma (Eriocera) brachycera

(Osten Sacken)

Shennomomylia lenta (Osten Sacken)

Hexatoma (Eriocera) brevioricornis

Alexander

Hexatoma (Eriocera) spinosa

(Osten Sacken)

Erroptera (Psiloconopa) venusta

Osten Sacken

Erioptera (Mesocyphora) caliptera X

Say

Brachypremna dispellens (Walker) X

Cladura flavoferruginea (Osten X

Sacken)

Limonia (Dicranomyia) pudica X

(Osten Sacken)

Ormosia rubella_(Osten Sacken)
$\mathrm{X}$

$X$

$X$

$\mathrm{X}$
$\mathrm{X}$

$\mathrm{X}$

$\mathrm{X}$

$\mathrm{X}$

$\mathrm{X}$

X

$\mathrm{X}$

X

X

X

X

X

X

X

X

$\mathrm{X}$

X

X

X

X 
KR

MH

Ulomorpha pilosella (Osten Sacken)

Trichocera brevicornis Alexander

Molophilus hirtipennis

(Osten Sacken)

Pedicia (Tricyphora) vernalis

(Osten Sacken)

Tabanidae

Tabanus sp. Linneaus

Chrysops sp. Meigen

Chrysops furcatus Walker

$\begin{array}{ll} & X \\ X & X \\ & X\end{array}$

$\mathrm{X}$

X

Stratiomyidae

Euparyphus sp. Gerstacker

X

$\mathrm{X}$

$\mathrm{X}$

$\mathrm{X}$

Xylophagidae

X

X

Sarcophagidae

X

$\mathrm{X}$

Micropezidae

X

$\mathrm{X}$

Drosophilidae

X

X

Chironomidae

Nilothauma sp.

(Chironominae)

Chironomus sp. Meigen

X

$\mathrm{X}$

Telmatoscopus sp. Eaton

Threticus sp. Eaton

$\mathrm{X}$
$\mathrm{X}$

$\mathrm{X}$

Asilidae

Diopsidae

Syphracephara brevicornis (Say)

$\mathrm{X}$

$\mathrm{X}$

$\mathrm{X}$

Dixa sp. Meigen

X

X

Pallopteridae

X

Culicidae

Anopheles punctipennis (Say)

Aedes apicalis Meigen

$\mathrm{X}$

$\mathrm{X}$

$\mathrm{X}$

$\mathrm{X}$

Lauxaniidae

Dolochopodidae

Telmaturgus parvus (Van Duzee)

$\mathrm{X}$

X

Dryomyzidae

X 
KR

Mycetophilidae

Sphaeroceridae

Muscoidea

Psyllidae

Bombyliidae
MH

X X

X X

X X

X $\quad$ X

X $\quad$ X


Appendix 3

\section{Community Metrics}

\section{Immatures and Adults:}

Total Number of Taxa

Total Number of Individuals

Total Number of Individuals per Taxon

Number of Ephemeroptera Taxa

Number of Heptageniidae Taxa

Number of Plecoptera Taxa

Number of Trichoptera Taxa

Number of EPT (Ephemeroptera, Plecoptera, and Trichoptera) Taxa

Number of Diptera Taxa

Number of Coleoptera Taxa

Number of Collector-Filterer Taxa

Number of Collector-Gatherer Taxa

Number of Predator Taxa

Number of Shredder Taxa

Number of Scraper Taxa

Percentage of Megaloptera

Percentage of Ephemeroptera

Percentage of Plecoptera

Percentage of Trichoptera

Percentage of EPT Taxa

Percentage of Chironomidae

Percentage of 1 Dominant Taxon

Percentage of 5 Dominant Taxa

Percentage of Heptageniidae

Percentage of Odonata

Percentage of Coleoptera

Percentage of Diptera

Percentage of Collector-Filterers

Percentage of Collector-Gatherers

Percentage of Predators

Percentage of Shredders

Percentage of Scrapers

\section{Also included for adults:}

Number of Total Adults

Simpson Diversity Index

Shannon Diversity Index 


\section{JUDITH S. STEINBERG \\ 625 North Morris Street \\ Waynesburg, PA 15370 \\ Phone: 724-627-8752 \\ e-mail: steinbrg@greenepa.net}

\section{EDUCATION:}

West Virginia University

Davis College of Agriculture, Forestry, and Consumer Sciences

Ph.D. in Agricultural Sciences with emphasis in Entomology

Dissertation: Relative Abundance, Temporal Distribution, and Functional Feeding

Groups of Aquatic Insects in Two First Order Southwestern Pennsylvania Streams

University of Delaware

M.S., May 1977

Department of Entomology and Applied Ecology

\section{Honors and Awards:}

- Outstanding Teaching Award - 1976

Dissertation: Time, Space, and Food Partitioning by Plecoptera in a First Order

Delaware Stream

Washington and Jefferson College

B.A. Magna Cum Laude, May 1974

Major: Biology

\section{TEACHING EXPERIENCE:}

\section{University of Delaware}

Teaching Assistantship (1974-1977)

- Instructor of General Entomology for undergraduate students; responsible for developing lab curriculum (3 class sections)

- Instructor for Ornithology for undergraduate and graduate students; responsible for lab field trips and lab sessions (1 class section)

- Instructor for Apiculture for undergraduate and graduate students; responsible for lab sessions and assessing student exams (1 class section)

Lawrenceville Catholic High School, Pittsburgh, PA

August 1977 - June 1979

- Designed curriculum for both lectures and labs

- Taught both lectures and labs

- Courses: Earth Science, Grade 9; Biology, Grade 10; Physics, Grade 12.

\section{WORK EXPERIENCE:}

\section{Steinberg Vision Associates, Waynesburg, PA \\ April 1978 - October 1999}

Office Manager

Varied duties including data entry of patient records; pre-testing of patients; optical patient fitting, ordering, and adjusting glasses; cutting and finishing lenses; use of molding system to manufacture lenses; hiring and training staff.

\section{INTERESTS:}

Hiking, backpacking, sewing, gardening, theatre, travel 